\title{
PRETORIA STUDENT LAW REVIEW (2011) 5
}

Pretoria Tydskrif vir Regstudente Kgatišobaka ya Baithuti ba Molao ya Pretoria

Editor in chief:

Ulrich Fobian

\section{Editors:}

Chastin Bassingthwaighte

Claire-Alice Smith

Serena Kalbskopf

Kenneth Sithebe

Nicole Breen

Mark Nichol

Thandi Tshabalala

Natasha Mandizha

Jared Schultz 


\section{(2011) 5 Pretoria Student Law Review}

\section{Published by: \\ Pretoria University Law Press (PULP)}

The Pretoria University Law Press (PULP) is a publisher, based in Africa, launched and managed by the Centre for Human Rights and the Faculty of Law, University of Pretoria, South Africa. PULP endeavours to publish and make available innovative, high-quality scholarly texts on law in Africa. PULP also publishes a series of collections of legal documents related to public law in Africa, as well as text books from African countries other than South Africa.

For more information on PULP, see www.pulp.up.ac.za

Printed and bound by:

Ultra Litho (Pty) Ltd

Johannesburg

\section{Cover:}

Layout: Yolanda Booyzen, Centre for Human Rights

Cover design: Dominic Vertue

Photograph on back cover: Grant Stephens

To submit articles, contact:

PULP

Faculty of Law

University of Pretoria

South Africa

0002

Tel: +27 124204948

Fax: +27 123625125

pulp@up.ac.za

www.pulp.up.ac.za

ISSN: 1998-0280

(c) 2013 


\section{TABLE OF CONTENTS}

Editors' note

Ulrich Fobian

On becoming a passionate lawyer

Pieter Carstens

Osama bin Laden: A war waged within the gaps in international law

Reuben Cronjé

Sarah McGibbon

Tranformative constitutionalism: Separatebut equal? A sceptical approach

Ruan du Toit

Stop the Beach Renourishment, Inc. $v$ Florida Department of Environmental Protection: An avulsion of littoral rights

Jeffrey Partlow

Access to social security for non-citizens: An international, South African and European view

Taryn Lee Vos

Post-apartheid reflections on critique,

transformation and refusal

Joel SM Modiri

Discussion on characterisation in South African private international law Justin Leach

Transboundary environmental pollution:

Understanding the intricacies of international law

Kshitij Bansal

Rose tinged memories: A family of strangers

Nozuko Siyotula 


\section{EDITORS' NOTE}

Legal writing is an essential element to the study of law, a concept the Board of 2011 understood. Nicole, Thandi, Serena, Jared, Clare, Chastin, Kenneth, Natasha and Mark committed to ensuring that this young legal journal produced passionate and professional articles. The Board never wavered from their task of guaranteeing that the authors flourished in their individuality. Topics vary from Osama bin Laden to environmental law, from a desperate plea for legal inspiration and passion to stellar philosophical arguments diffusing complex situations. The essence of legal writing has been laid out for the reader/researcher in this journal - the fifth (2011) edition of the Pretoria Student Law Review (PSLR).

The PSLR is for legal scholars, not just from the University of Pretoria, who are able to see that a one-dimensional approach to the study of law cannot stand. To simply float through studies, barely ever fully conscious, only suffocates the integrity of the legal profession and hampers the progression of law in South Africa. In the dynamic and challenging field we as legal academics and lawyers have chosen to embrace, there needs to be a humility that enables us to see how little we know and how unjust we are despite the supreme Constitution, in order that we may be driven forward in search of solutions. GK Chesterton states that the definition of humility has altered and may be the very reason passion has flown out the window:

The truth is that there is a real humility typical of our time; but it so happens that it is practically a more poisonous humility than the wildest prostrations of the ascetic. The old humility was a spur that prevented a man from stopping; not a nail in his boot that prevented him from going on. For the old humility made a man doubtful about his efforts, which might make him work harder. But the new humility makes a man doubtful about his aims, which will make him stop working altogether. ${ }^{1}$

This unique journal is there for those students who understand the 'old humility' and are willing to digest current events, laws and rules.

The PSLR acquired an office in 2011. This has been a great help in the Board's pursuit of professionalism and efficiency. To have 'a space to call our own' has not only allowed for creativity, but also for ensuring that the creative ideas materialise into the desired realities. 2011 has seen the Board continue to include a note from the opposite side of the spectrum - the lecturer's point of view; Professor Pieter Carstens has kindly written this year's note. A special thanks to Professor Carstens for this valuable contribution.

A short story from the Faculty of Law's (University of Pretoria) Faculty Festival is included in this edition. The theme of the Festival 
was heritage and the story, although not strictly speaking legal, does display the importance of creativity in the study of law.

Unfortunately there are always those hard workers who are not credited for the valuable work they do. With this in mind, I would like to specially mention Elzet Hurter for her constant assistance; Professor Anton Kok for his mentorship in the development of the journal; Serena Kalbskopf and Mark Nichol for tackling the hard job of making sure the journal is ready for print; Dominic Vertue, Mark Nichol and Clare Smith for the front cover; Grant Stephens for the photograph on the back.

In reading this journal I hope you are able to doubt yourself and the law, so that you in turn may discover your niche in this profession, forever testing the status quo.

\section{Ulrich Fobian}

(Editor-in-Chief 2011) 


\section{NOTE ON CONTRIBUTIONS}

We invite all students to submit material for the sixth edition of the Pretoria Student Law Review. We accept journal articles, case notes, commentary pieces, response articles or any other written material on legal topics. You may even consider converting your research memos or a dissertation chapter into an article.

Please visit our website at www.pslr.co.za for more information.

You may submit your contribution to pslr@up.ac.za.

Alternatively you may submit your contribution by hand at the office of the Dean of the Law Faculty:

Dean's Office

Faculty of Law

4th Floor

Law Building

Unversity of Pretoria

Pretoria

0002 


\title{
ON BECOMING A PASSIONATE LAWYER
}

\author{
by Pieter Carstens*
}

\section{Some reflections}

Henry David Thoreau, the American scholar-gipsy, poet, naturalist, moralist, and above all, transcendentalist, wrote the following, much quoted, passage in his famous book: ${ }^{1}$

I went to the woods because I wished to live deliberately, to front only the essential facts of life, and see if I could not learn what it had to teach, and not, when I came to die, discover that I had not lived ... I wanted to live deep and suck out all the marrow of life, to live so sturdily and Spartan-like as to put to rout all that was not life, to cut a broad swath and shave close, to drive life into a corner, and reduce it to its lowest terms, and, if it proved to be mean, why then to get the whole and genuine meanness of it, and publish its meanness to the world; or if it were sublime, to know it by experience, and be able to give a true account of it in my next excursion.

Thoreau's passionate words seem to be a logical point of departure when reflecting on the emotion of passion in context of lawyers and more specifically law students (as aspirant-lawyers). Why, one may ask, is it necessary to assess passion for the law with reference to law students? As a lecturer, however, I have come to the realisation that the hallowed halls of academia have, of late, become hollow with the apparent lack of interest in the law by many law students. Many of them have become disengaged, disinterested, and dare I say, disenchanted with the study of law. Very few 'live and study law deliberately' and certainly only the exceptional students 'suck out the marrow of the law'! Why is this so? Why has the study of law apparently become institutionalised, monotonous and, ultimately, mediocre? What has happened to the 'starry-eyed'-first year student who enrolled for law 'in the pursuit of justice and the truth', who, fuelled by an undaunted idealism, wanted to study law 'for the greater good of society'? This idealism seemingly evaporates over the years of the study of law, and many senior law students are reduced to credit-collecting, minimalist survivors who resist attendance of lectures, the research of case law and materials, lamenting about time tables, and only thriving on the memorising of previous test and

* Professor, Department of Public Law, University of Pretoria; Associate member of the Pretoria Bar.

1 HD Thoreau Walden (1854) (quoted from the 1945 edition) (WH Dircks (ed)) 88. 
examination-papers. Why, on a dramatic note, have they become so disillusioned? The answer in my opinion is simple: it is a matter of passion (or rather the lack thereof)!

The question to be posed then, is how does one rekindle the passion for law? It needs to be stated that a career in law is not primarily an exercise in the accumulation of material wealth, status and glamour! Those who make this their aim will certainly die disappointed! A successful career in law is not only dependent on a combination of knowledge, appropriate legal skills and experience, but also requires character, personality, dedication, commitment and professionalism. This is the first principle about rekindling passion for the law: know the requirements for the legal profession and then one will know what is expected - if one understands what the professional expectations are, then 'live-up' to those expectations (or at least try to cultivate them). In this regard (in context of professional expectations), much is to be gleaned from the American Bar Associations" ${ }^{2}$ identification of the ten fundamental skills and four fundamental values which every successful lawyer should possess the ten fundamental skills are: (1) problem solving; (2) legal analysis and reasoning; (3) legal research and writing; (4) fact investigation; (5) communication; (6) counselling; (7) negotiation; (8) litigation and alternative dispute resolution procedures; (9) organisation and management of legal work; (10) recognising and resolving ethical issues. The four fundamental values are: (1) providing competent representation; (2) striving to promote justice, fairness and morality; (3) striving to improve the profession; and (4) engaging in professional self-development. One would, however, be naïve to think that by simply slavishly implementing these listed skills and values on a daily basis passion for the law will follow as a matter of course. For passion to be rekindled one needs passion in itself! This is the second principle: the listed skills and values will only enhance one's professional life if these are pursued with passion; in this sense passion becomes, the elixir, as it were, for the development of these skills and values, without which the pursuit thereof becomes meaningless! While skills and values can be acquired, it needs passion, which comes from within, to propel these skills and values forward to professional articulation.

In order to know one's passion for the law, one has to discover one's passion. How is this achieved? This is the third principle: discovery of one's passion requires focus, and focus requires specialisation in law. The simple truth is that the field of law today is

'Legal education and professional development - An educational continuum' (1992), as quoted by and incorporated into CG Marnewick SC Litigation skills for South African lawyers (2007) x; for a discussion of justice and passion in historical context, compare The mediations of Marcus Aurelius trans G Long in The Harvard classics (1937) Vol $2193 \mathrm{ff}$. 
just too wide, too complex and too diverse to be a generic 'jack-ofall-trades'. The diversity in the legal field is, however, also its strength - we need legal philosophers, legal historians, tax lawyers, divorce lawyers, criminal law lawyers, human rights lawyers, constitutional lawyers, company law lawyers etc. The sooner one starts to specialise in law, the sooner one will discover one's passion for the law. As a student, one has to align oneself to that field of law or speciality which strikes at one's interest, bearing in mind one's personality, talents, hopes and aspirations. This brings one to the fourth principle: students need to understand that one will practise law as an individual and not as a collective group. People, in their quest for professional self-actualisation, traditionally enter the professions precisely because of their individual talents. One should therefore individualise one's approach to legal studies, acquiring skills and values, honing/sharpening them to perfection to set oneself apart from the collective group, realising that individuality generates and inspires passion, while the collective group, although important, tends to inhibit passion. It is individual passion that will secure success in the practice of law.

Drawing from my own experience, I was fortunate to 'discover' and 'focus' on medical law, as an elective, in my final year of undergraduate study. In hindsight, it was a life-changing encounter and three decades later I am still haunted by medical law. Medical law taught me that law is transcendental in nature and can never be an end in itself. Law only has meaning when viewed as a means. One can only assess the value and significance of law in light of how successful and effective means it proves to be in relation to a particular end. That end, hopefully, is justice within the specific context in which the law has applied. Medical law thus catapulted my young and vulnerable mind into an understanding that law begs the question of application and application begs the question of context. Immersing myself in this specialised area of law, I came to realise that the foundational principles of medical law are but facets of a larger whole, that they are not discrete and cannot be isolated from the other fields of law that link them all - comparable to a crystal lattice. In time, I came to know that like most crystals, the law is not perfect. It has its flaws, but like crystals in their natural environment, the law is capable of refinement, growth and development. It is subject to all kinds of environmental pressures and forces. It is a dynamic system. Herein lies hope for positive change and growth and the possibility of remedying the flaws that impair its purity and beauty. For law is beautiful - it has a certain elegance of logic, a certain rightness of reason, which when correctly understood and applied, is no less entrancing than the constructs of higher mathematics. ${ }^{3}$ Needless to 
say, I became infatuated with medical law - I believed that this would make me, as a lawyer, invincible and irresistible! This is the fifth principle: once one has aligned oneself to a specific speciality and focus in law, it is precisely this focus that will 'demystify' one's clogged comprehension of the rest of the seemingly tedious law curriculum. One's passion for one legal subject can thus serve as a kind of 'aversion therapy' against all those legal courses which one finds unappealing!

Once one has rekindled the passion for law, it needs to be sustained. This is the sixth principle: to sustain one's passion for the law, one has to constantly work at it - be curious; be inquisitive; be critical; be disciplined; pursue excellence; be prepared to challenge and to be challenged; read, research and above all, write about it always remember that 'reading makes a full man; conference a ready man, and writing an exact man." 4 These considerations, infused with enthusiasm and dedication, will become the driving force for one's hopes and aspirations on becoming a passionate lawyer. Above all, a passionate lawyer recognises the tradition of respectful argument. This is the seventh and last principle: the mark of a passionate lawyer is his/her ability to differ without becoming angry, sarcastic or discourteous. Such a lawyer recognises that in contingent matters there will always be a place for legitimate difference of opinion. The ability to defend one's position with spirit and conviction; to evaluate accurately the conflicting opinions of others and to retain one's confidence in the ultimate power of truth to carry its own weight, are necessary talents in any society and the essential tools of a passionate lawyer. ${ }^{5}$

Coming to the present issue of this journal at hand, I am particularly impressed and heartened by the scholarly level of the respective contributions. It is evident that the various authors are already discovering their focus and specialisation, and by implication are solidly on their way to become passionate lawyers! Those of us, who have been the strictest searchers in our quest to become passionate lawyers, will advise the present authors, that the 'sweetest marrow to be sucked out of the law' is the preserve of passionate lawyers who strive to be scholarly lawyers! It's only in the reading, the researching and the writing of the law that truth and beauty abound and living (in the words of Thoreau) indeed becomes deliberate! I rest my case, with full and complete allegiance to the closing remarks of the late, great Harry Morris QC who wrote:

4 In the words of Francis Bacon, Viscount of St Albans, English Lord Chancellor in Of Studies (1626) as quoted in Dictionary of Quotations and Proverbs (1982)(DC Browning (ed)) 22.

5 The last principle is an adaptation from JP Shannon 'The tradition of respectful argument' in RL Varco \& JP Delaney (eds) Controversy in surgery (1976) 27. See also J Munkman The technique of advocacy (1991) 4. 
Scholars! "Who", you may ask, "are the scholars?" As I near the end of my thesis and as I recall some 45 years in which my stumbling footsteps have traced the path I offer you for your journey, I feel that I can now answer that question. I am a scholar. As I write, I must think, and I must reason the why and wherefore. And if I pretend to teach, it is no more than a whimsical impertinence on my side. For in the writing and in the thinking and in the evolving of the why and the wherefore, I am teaching - teaching myself. Nor yet do I consider my lessons to have been well learned. Nor yet have I met a colleague who himself is learned beyond learning. Nor yet, least of all, can I be sure that what I advise is free of folly. I trust that I write with humility when I record that even in the greatest have I seen error. And is error anything more than a lesson yet to be learned? In every case, every consultation, every opinion, is to be found something to be learned. There is law to be learned, and foresight, and knowledge of humanity. If from these teachers you do not learn you may well fall by the wayside. May you, too, be one of the scholars. ${ }^{6}$ Technique in litigation [1969] (2010) 416. 



\title{
OSAMA BIN LADEN: A WAR WAGED WITHIN THE GAPS IN INTERNATIONAL LAW
}

\author{
by Reuben Cronjé* \& Sarah McGibbon**
}

\section{Introduction}

The recent demise of arch-terrorist Osama bin Laden at the hands of United States (US) Navy Seals has given rise to furious debate as to the legality thereof. The broadest question to ask is whether bin Laden's killing can be justified in terms of international law. Indeed, it is not even clear which legal paradigm should be utilised to answer this conundrum. In this article it will be shown that the American term, 'war on terror', does not fit neatly into the definition of either an international or non-international armed conflict and is therefore not comfortably governed by the rules of either. The concept of selfdefence, desperately needing clarification, will then be proposed as something which operates outside these two paradigms. The aforementioned discussions will lead to an analysis of whether the correct over-arching legal system to apply is international humanitarian law (the law of war) or international human rights law; or whether these two can legitimately operate concurrently. Finally, some brief thoughts will be added regarding the legality of the actual killing of bin Laden.

\section{The nature of the conflict - War or not?}

In order to make any sort of meaningful judgment upon the legality of bin Laden's killing, it must first be established which body of rules governs the relevant events. This body of rules would either be international humanitarian law (IHL) or international human rights law (IHRL). The 'war on terror' is an armed conflict and humanitarian law seems like the natural starting point. However, in order to determine its suitability for governing bin Laden's killing, the nature of the conflict must be established, with regards to whether it does in fact fall within the definitional requirements of 'war', such that the governing rules will apply. The international law of war can be categorised in numerous ways based on the character of the conflict

*** $\quad$ Final year LLB (University of KwaZulu-Natal).

Final year LLB (University of Pretoria). 
itself. However, in terms of the Geneva Conventions, ${ }^{1}$ being the preeminent instruments on the subject, the first distinction to be drawn is between so-called 'international' and 'non-international' armed conflicts. If a conflict were to fall outside either of these two categories, then IHL would likely not apply, with either IHRL or a hybrid right's system applying - the applicable regime is discussed fully in part 3 below.

\subsection{Definitions of international and non-International armed conflict}

As suggested by Dinstein, ${ }^{2}$ war in the international sense is characterised primarily by the protagonists being states, not merely non-state actors. Such an international armed conflict can exist irrespective of any formal declaration of war, ${ }^{3}$ although this would go a long way towards determining the existence of that war. In fact, the key factor is the comprehensive use of force by at least one party to the hostile interaction. ${ }^{4}$

By contrast, Additional Protocol II (APII) of the Geneva Conventions defines non-international armed conflicts as those: ${ }^{5}$

[W]hich take place in the territory of a High Contracting Party between its armed forces and dissident armed forces or other organised armed groups which, under responsible command, exercise such control over a part of its territory as to enable them to carry out sustained and concerted military operations and to implement this Protocol.

There is a clear difference between the two contemplated scenarios. International conflicts are exclusively those fought between states, whereas non-international armed conflicts occur between the state and one or more non-state actors. The Additional Protocol was enacted to extend some aspects of the Geneva Conventions to protect the victims of non-international armed conflict, as the original four conventions only granted scant protection in the form of Common Article $3 .^{6}$ On the language of both the Geneva Conventions and APII, there is no contemplation of international and non-international

$1 \quad$ First Geneva Convention, 1949; Second Geneva Convention, 1949; Third Geneva Convention, 1949; Fourth Geneva Convention, 1949.

2 Y Dinstein War, Aggression and Self-defence (4th edition) (2005) 15.

Common Article 2, Geneva Conventions.

As above.

Additional Protocol II (Geneva Conventions) 1977.

Art 3 In the case of armed conflict not of an international character occurring in the territory of one of the High Contracting Parties, each Party to the conflict shall be bound to apply, as a minimum, the following provisions:

(1) Persons taking no active part in the hostilities, including members of armed forces who have laid down their arms and those placed hors de combat by sickness, wounds, detention, or any other cause, shall in all circumstances be treated humanely, without any adverse distinction founded on race, colour, 
conflicts being interchangeable - only the rules set out for each will apply to the relevant conflict.

\subsection{Is the conflict an international armed conflict?}

The Authorisation for Use of Military Force (AUMF), ${ }^{7}$ passed in response to the terror attacks on the US by Al-Qaeda, makes it clear that any military actions taken against Al-Qaeda targets are not necessarily against other states - the authorisation extends to the use of force against 'nations, organisations or persons' 8 In the specific instance of the raid on bin Laden's stronghold, the only potential states which could be waging an international armed conflict are the US and Pakistan. However, it would be untenable to maintain such a contention in light of both the US and, especially, the Pakistani governments' reaction ${ }^{9}$ to the raid (Ex-President Musharraf's contention of a 'violation of our sovereignty' ${ }^{10}$ notwithstanding). The conflict can certainly not be categorised as an international one - the requisite level of force is absent as there is simply no conflict in the sense of an exchange of hostilities between the two states, ${ }^{11}$ and there is certainly no formal declaration of war between the United States and Pakistan. Thus, it neither satisfies the material or technical requirements essential for war. ${ }^{12}$ The US is certainly waging war against some party, be it Al-Qaeda, or specifically Al-Qaeda Pakistan, but this should not be conflated with the waging of war

religion or faith, sex, birth or wealth, or any other similar criteria.

To this end the following acts are and shall remain prohibited at any time and in any place whatsoever with respect to the above-mentioned persons:

(a) violence to life and person, in particular murder of all kinds, mutilation, cruel treatment and torture;

(b) taking of hostages;

(c) outrages upon personal dignity, in particular humiliating and degrading treatment;

(d) the passing of sentences and the carrying out of executions without previous judgment pronounced by a regularly constituted court, affording all the judicial guarantees which are recognised as indispensable by civilised peoples.

(2) The wounded and sick shall be collected and cared for.

An impartial humanitarian body, such as the International Committee of the Red Cross, may offer its services to the Parties to the conflict. The Parties to the conflict should further endeavour to bring into force, by means of special agreements, all or part of the other provisions of the present Convention. The application of the preceding provisions shall not affect the legal status of the Parties to the conflict.

7 Authorisation for Use of Military Force, 18 September 2001, Public Law 107-40 [SJ Res 23].

8 n 7 above, s2(a). $A B C$ News 2 May 2011 http://abcnews.go.com/Politics/osama-bin-laden-killedpakistan-reacts-cautiously-us/story?id=13507918\&page $=2$ (accessed 3 August 2011).

10 JJ Xenakis 'Big Peace: Pakistan's schizophrenic reaction to bin Laden killing' 3 May 2011 http://bigpeace.com/jxenakis/2011/05/03/pakistans-schizophrenicreaction-to-bin-laden-killing/ (accessed 3 August 2011).

11 As above.

12 Dinstein (n 2 above) 15 
against the state in whose territory this conflict happens to be occurring.

\subsection{Is the conflict a non-international armed conflict?}

If the attack against bin Laden was not part of an international armed conflict, then it remains to be established whether or not it forms part of a non-international armed conflict. To this end, the definition contained within APII must be scrutinised further. On a plain reading of the definition, it seems that a war waged between an 'organised armed group' and a third party state - that is, not the state in whose territory the conflict is occurring - is excluded from being a noninternational armed conflict. Put differently, in this scenario, it would only qualify as a non-international armed conflict if (i) Pakistan was, on the one side, involved in the hostilities; or (ii) instead of taking place in Pakistan, the attack, and the rest of the armed conflict, took place in the US.

There is some amount of academic support for the contention that the war against Al-Qaeda in Pakistan is not a non-international armed conflict. Marko Milanovic states that: ${ }^{13}$

As for [international humanitarian law], the jus in bello, it either does not apply at all as the killing was not done as a part of any legally cognisable armed conflict (probably the better view), or [bin Laden] was a lawful target as a leader of an organised armed group taking part in a non-international armed conflict ...

The implication of the above discussion would be that the conflict with Al-Qaeda falls into a gap within IHL, being neither an international nor a non-international armed conflict. The result of this is that there is in fact an armed conflict governed by no existing humanitarian law system. Kretzmer, however, strongly rejects such a standpoint. ${ }^{14}$

Kretzmer postulates that, traditionally, targeted killings can be seen as part of a law-enforcement model, or an armed conflict model. ${ }^{15}$ The authors are inclined to say that the former is the least robust, as law-enforcement implies sovereign control over the target of that enforcement. The armed conflict model relies on IHL, but this again brings the discussion back to whether the war against Al-Qaeda satisfies APII. Kretzmer is supportive of the view that the conflict could indeed be considered to be a non-international armed conflict regardless. This viewpoint suggests that even though the Geneva

13 M Milanovic 'When to kill and when to capture?' 6 May 2011 http://www.ejil talk.org/?s=when+to+kill+and+when+to+capture (accessed 31 July 2011).

14 D Kretzmer 'Targeted killing of suspected terrorists: Extra-judicial executions or legitimate means of defence?' (2005) 16 European Journal of International Law 175.

15 Kretzmer (n 14 above) 176 \& 186. 
Conventions and APII do not apply formally, the law of noninternational armed conflicts forms part of customary international law. ${ }^{16}$ The international community would surely not accept that certain armed conflicts could simply 'fall into the gap'. This is especially true given that many states, particularly in Africa, suffer attacks from rebels or insurgents that base themselves in neighbouring countries. ${ }^{17}$ The international community, therefore, accepts that the customary law of non-international armed conflict extends to the scenario where third party states operate against nonstate actors.

\subsection{Self-defence as an alternative to international or non- international armed conflict}

Despite the argument in the previous paragraph, it is submitted that it is unnecessary to stretch and twist the existing definitions of armed conflict. Indeed, whilst the US government itself does subscribe to the notion that it is waging a non-international armed conflict, it does not necessarily rely on this as the basis for its actions against Al Qaeda. ${ }^{18}$ The US instead relies on article 51 of United Nations Charter (the Charter), which permits states to act in self-defence. ${ }^{19}$

The Charter outlines the right of member states as follows: 'Nothing in the present Charter shall impair the inherent right of individual or collective self-defence if an armed attack occurs against a Member of the United Nations. 20 This is the sole exception to the prohibition on the use of force by UN member states outside of the structures of the UN Security Council, and this underlines its status as a unique element of international law. It could be considered sui generis and as such, it does not fall under the traditional umbrella of an international or non-international armed conflict in a situation where a third party state pursues an armed conflict against a nonstate actor. ${ }^{21}$ Furthermore, it should be noted that nothing in article 51 of the Charter excludes the possibility of an armed attack made by a non-state actor, nor does it restrict the self-defence to being within the borders of the victim state. 22

16 Kretzmer (n 14 above) 195.

17 Armed activities on the territory of the Congo (Democratic Republic of the Congo $v$ Uganda) (19 December 2005) (2005) ICJ Reports 168; separate opinion of Judge Kooijmans, 308.

18 Hamdan $v$ Rumsfeld, 126 S.Ct. 2749, 2795-2796 (2006).

19 PM Cullen 'The role of targeted killing in the campaign against terror' (2008) 48 Joint Force Quarterly (1st quarter) 24.

20 Article 51, United Nations Charter (chapter 7).

21 JJ Paust 'Self-defense targeting of non-state actors and permissibility of US use of drones in Pakistan' (2010) 19.2 Journal of Transnational Law and Policy 280.

22 Legal Consequences of the Construction of a Wall in the Occupied Palestinian Territory (9 July 2004) (2004) ICJ Reports 136; separate opinion of Judge Kooijmans, 229-230; Paust (n 21 above) 241. 
When looking at the specific matter of bin Laden's killing it is necessary to draw a distinction between the jus ad bellum, whether the 'war on terror' is justifiable in terms of international law, and the jus in bello, whether the specific act is justifiable. The two cannot be 'rolled into one'. As Kevin J Heller writes: ${ }^{23}$

[I]f the objective requirements of armed conflict do exist, [international humanitarian law] applies even if article 51 did not authorise the operation; [international humanitarian law] does not distinguish between just and unjust, legal or illegal, uses of force. (Which means that it is perfectly legal for a soldier fighting an illegal war to kill an enemy combatant.) Conversely, if the objective requirements of armed conflict do not exist, IHL does not apply even if article 51 did authorise the operation. The jus ad bellum question is irrelevant to the jus in bello one.

Heller's contention that IHL is the applicable system aside, the above serves to illustrate the separation between jus ad bellum and jus in bello. If a war is permissible in terms of the jus ad bellum, it means that the war can be considered a 'just war', 24 meaning that the party is entitled to wage that war. Specific acts committed in the waging of a war, however, may be just or unjust per se, and are considered on their own merits. If the specific act is permissible in terms of the governing legal regime, then the jus in bello requirement is satisfied. What Heller is noting is that the two cannot be conflated. The fact that a war itself qualifies as an armed conflict under some or other regime does not imply that specific acts committed in pursuance thereof are legal. The converse also holds true: a specific act which is justifiable in terms of, say, IHL is not rendered illegal by the absence of jus ad bellum.

Thus, although article 51 self-defence may legitimise the 'war on terror', it does not necessarily give sanction to the specific incident of bin Laden's killing. That is, the jus ad bellum requirement is met but the governing regime of the jus in bello is still unclear and thus it is uncertain whether bin Laden's killing is justified. To this end, it must be established which paradigm applies to hostilities conducted under article 51 of the Charter in order to determine whether the requirements under that system are met for the specific act. As discussed below, this may be international human rights law, international humanitarian law, or some hybrid operation of the two.

KJ Heller 'Quick thoughts on UBL's killing - and a response to Lewis' 4 May 2011 http://opiniojuris.org/2011/05/04/quick-thoughts-on-ubls-killing-and-a-response -to-lewis/ (accessed 27 July 2011).

24 A Mosely 'Just War Theory' 10 February 2011 http://www.iep.utm.edu/justwar/ (accessed 9 September 2011); according to Mosely, the factors to be considered in determining a 'just war' are as follows: 'having just cause, being a last resort, being declared by a proper authority, possessing right intention, having a reasonable chance of success and the end being proportional to the means used'. 


\section{The legal regime applicable to bin Laden's killing}

The question of which legal regime should apply to the situation of bin Laden's killing is a contentious one and must be considered with regard to all the relevant facts. In order for IHL to apply, there must have been an armed conflict of either an international or a noninternational nature. As previously mentioned, this is because a conflict falling outside the definitions cannot be covered by the relevant international conventions. Therefore, when an armed conflict is a self-defence 'war' conducted under article 51 of the Charter against a non-state actor by a third party state, the applicable law could well be IHRL or IHL. Firstly, however, the relationship between these two regimes must be established.

\subsection{The relationship between international humanitarian law and international human rights law}

As discussed above, the 'war on terror' does not fit neatly into the definition of either a non-international or an international armed conflict. As such, one cannot merely apply the rules of IHL as set out in the Geneva Conventions and their additional protocols. In an ordinary war situation, IHRL would have to take a backseat to make way for IHL as the specific law applicable to armed conflicts, termed the lex specialis. The traditional viewpoint is that there must be complete separation between these two regimes, however, the principles of IHRL cannot be ignored.

There are many similarities between IHL and IHRL, including the fact that they are governed by the same goals and fundamental principles. ${ }^{25}$ Pictet argues that the whole body of IHL may be traced back to the inherent obligation to respect human dignity that exists even during periods of war. ${ }^{26}$ However, it is clear from the wording of many IHRL instruments that sometimes the principles of IHRL lack succinct and practical definitions, and as a result, their application becomes difficult. This is where IHL steps in to regulate areas that are insufficiently regulated by IHRL. ${ }^{27}$ It is, essentially, the fundamental principles of IHRL adapted to suit the specific situations created by armed conflicts. For example, the Fourth Geneva Convention (which sets out the law with regard to the protection of civilians during

H Gasser 'International humanitarian law \& human rights law in non-international armed conflict: Joint venture or mutual exclusion' (2002) 45 German Yearbook of International Law 155.

26 J Pictet 'Les Principes du droit international humanitaire', in R Bernhardt R (ed) Encyclopaedia of Public International Law (1995) 11922.

$27 \quad$ Gasser (n 26 above) 157. 
international armed conflict) deals extensively with issues that, during peacetime, are exclusively governed by IHRL.

The common principle underlying both regimes is the principle of humanity. This principle requires that the inherent dignity of every human being be recognised and protected. ${ }^{28}$ Furthermore, the Tehran Proposals and Resolution 2444 (XXIII) of the UN, dealing with respect for human rights during armed conflict, underscore the close relationship between these two regimes.

There are also many differences between the two, such as their different areas of applicability and different histories. ${ }^{29}$ IHRL protects the fundamental rights of any individual against the abuse of power by a state or an authority exercising de facto control over the individuals, and it is applicable at all times (i.e. it is the lex generalis). IHL on the other hand, is never applicable during peacetime and plays the role of lex specialis during times of war. It is then clear that although the two bodies overlap, the situations to which they apply have always been, and always will be, different. Nevertheless, it is undoubtedly possible for the two to co-exist. ${ }^{30}$

\subsection{A combined approach to international humanitarian law and international human rights law}

Despite the preceding discussion, it has recently been contended that total separation is not necessary or indeed possible. Milanovic holds the view that the two are complementary and may apply at the same time. ${ }^{31}$ In terms of this position, the rules of IHRL will apply even where the rules of IHL do apply in order to set out more stringent requirements than those prescribed by IHL. Further, although the IHRL requirements will be more stringent than those of $\mathrm{IHL}$, the rules of IHRL during war will be less stringent than those developed for peacetime. In terms of this approach, a killing that complies with all the requirements of IHL must also be assessed in terms of IHRL to determine whether it is an arbitrary killing. Kretzmer also supports this 'middle road' approach. ${ }^{32}$ However, Kretzmer's approach differs in that according to his view, one must consider the principles of IHL in order to determine whether a killing was arbitrary or not. If the killing complies with the rules of IHL then it is not 'arbitrary' for the purposes of international law.

There is merit in Milanovic's view and if it were applied to the situation at hand then it would have been necessary to attempt to

Gasser (n 26 above) 155.

Gasser (n 26 above) 150.

Legality of the threat or use of nuclear weapons, advisory opinion (8 July 1996)

(1996) ICJ Reports 226.

31 Milanovic (n 13 above).

32 Kretzmer (n 14 above) 212. 
effect capture instead of killing bin Laden had the circumstances allowed for it. The reason for this is the fact that in terms of the human rights paradigm there is a positive obligation to effect capture instead of killing the target where it is safe to do so. ${ }^{33}$ This is a factual question that must be considered in light of the facts surrounding the raid of bin Laden's bunker that have slowly emerged. However, it must be borne in mind that this approach of applying IHRL to the principles of IHL will only be appropriate if the rules of IHL do apply to the situation in question.

\subsection{The application of international human rights law}

From the above discussion, one may now begin to determine which regime applied in Pakistan at the time of the killing of bin Laden. If one accepts that the killing did take place in the context of an armed conflict then it may be possible to apply the principles of IHL. However, the fact that the 'war on terror' (and any actions executed in continuance of such war) seems to fall within the gap between international and non-international armed conflicts - due to it being an armed conflict conducted under the self-defence paradigm- means that it is unlikely that one can merely consider the principles of IHL. If this anti-terrorism warfare does not meet the objective requirements for the application of the rules of IHL with absolute certainty, then the only solution is to resort to the broader principles embodied in IHRL. Therefore, it is submitted that the only way to proceed with a consideration of the legality of bin Laden's killing is by applying IHRL only. ${ }^{34}$

An old provision of international law exists, called the Martens Clause. This clause provides that where the specific rules of IHL do not apply, actions of combatants may be judged (and ultimately prosecuted) based on 'the principles of international law derived from established custom, the principles of humanity and from the dictates of public conscience'. ${ }^{35}$ This clause thus makes provision for the application of the rules of IHRL in situations such as the one currently under consideration.

The fact that IHRL does not take into account the special circumstances and purpose of armed conflict means that the actions of the US will be judged in light of principles with much broader application and more stringent requirements. For example, while IHL would allow the killing of bin Laden as a combatant (as a person in a

Milanovic (n 13 above)

This is not to say that IHL and IHRL can never exist concurrently, only that they do not exist concurrently in this situation due to the fact that this conflict is not covered by the relevant definitions for IHL to be applicable.

Martens Clause, Hague Convention II, 1899. 
commanding position), ${ }^{36}$ IHRL prescribes much stricter compliance with its principles aimed at the protection of the right to life.

The most notable international convention protecting the right to life is the International Covenant on Civil and Political Rights (ICCPR). The ICCPR stipulates that member states may not arbitrarily deprive a person of his or her life. ${ }^{37}$ The baseline by which 'arbitrariness' is judged is the standard of absolute necessity and reasonable proportionality. ${ }^{38}$ Thus, in terms of the IHRL paradigm, lethal force is only allowable in order to protect life from unlawful violence, ${ }^{39}$ and facts such as the absence of armed hostilities in the area, the presence of civilians in the compound, and bin Laden's unarmed state will all negatively impact on the legal implications of the US' actions. It is difficult to conceive a situation such as this one presenting an immediate threat to life such that killing bin Laden was necessary to avert that threat. While public opinion may be that he had already used lethal force on thousands of American civilians and his killing was justified, one cannot resort to the ancient talio principle (an eye for an eye) when trying to create an international culture of human rights awareness and protection.

The US has maintained that it does not owe a duty to respect the rights contained in the ICCPR extraterritorially, as the rights contained therein only apply to persons on US territory. ${ }^{40}$ Thus, on this argument, the US was not obliged to respect bin Laden's right to life. However, the ICCPR is not the only instrument that enshrines the right to life on an international level. The Universal Declaration of Human Rights ('UDHR') also protects the right to life and, unlike the ICCPR, its extraterritorial application is ensured by articles 28, 29 and 30 thereof. Therefore, the US is still bound to observe this right when acting outside US territory, and would do well not to forget this.

If this raid was not governed by IHL, the killing of bin Laden - with no attempt to use non-lethal force when it was possible - is illegal and amounts to an arbitrary deprivation of life, as there was no threat which required immediate action in order to satisfy the need for absolute necessity. It has become clear from statements by US officials that there was no intention of taking bin Laden alive unless

Paust (n 21 above) 261.

Article 6(1), ICCPR.

Paust (n 21 above) $268 \& 270$.

Convention for the Protection of Human Rights and Fundamental Freedoms, Nov. 4, 1950, 213 UNTS 221, Europe. T.S. No. 5.

40 KJ Heller (2006) 'Does the ICCPR Apply Extraterritorially?' 18 July 2006 http: // opiniojuris.org/2006/07/18/does-the-iccpr-apply-extraterritorially/ (accessed on 2 November 2011). 
he actively surrendered or was incapacitated and, thus, hors de combat. ${ }^{41}$ Such a callous disregard for principles of customary international law is unacceptable and, if left unaddressed, could lead to great problems in the future.

\subsection{A brief overview of the application of the combined approach}

Part 3.3 above notwithstanding, if the view is taken that the rules of IHL are applicable - although this is not the view taken by the authors - then the combined approach advocated by Milanovic must be applied. The question that should then be asked is whether, although bin Laden was a legitimate target for IHL purposes, in the specific circumstances of the killing, it was not still an arbitrary execution in terms of article 6 of ICCPR. In terms of Kretzmer's approach, the killing will be legal if it meets the requirements of IHL. Perhaps the conclusion reached in terms of each approach will be different. However, consideration must be given to the fact that Milanovic is more aligned with the human rights paradigm, whilst Kretzmer is attempting to create a situation that would allow countries to adequately defend themselves while still upholding the principles of IHL and IHRL. Due to the fact that IHL does, as previously discussed, allow for the killing of a person in a greater number of circumstances than IHRL, it is logical to conclude that the view aligned with IHL will be more permissive than the view in terms of IHRL.

\section{Conclusion}

If one considers that the purpose of war is essentially to weaken the military force of the enemy, it immediately becomes clear that acts of terrorism, so prominent in the 21st century, have given a whole new meaning to the concept of 'war'. If one accepts that killing civilians in fact weakens the morale and support structures of the combatants, then perhaps nothing has changed. However, it is hard to imagine that such an extrapolation of the concept is acceptable to the current rights-conscious international community. Alternatively, it may be contended that the 'war on terror' in fact falls exactly into the abovementioned purpose of weakening the enemy's military strength. After all, the US did in fact declare a 'war on terror' and a war against Al-Qaeda. Armed conflict is merely a war by a different

41 M Spetalnick (2011) 'US team's mission was to kill bin Laden, not capture' 2 May 2011 http: //www.reuters.com/article/2011/05/02/us-binladen-kill-idUSTRE7413 H220110502 (accessed on 15 September 2011); J Bendery (2011) 'John Brennan: We would have taken Osama bin Laden alive [UPDATE]' 2 May 2011 http:// www.huffingtonpost.com/2011/05/02/brennan-we-would-have-taken-bin-ladenalive_n_856541.html (accessed on 15 September 2011). 
name and while some may have their doubts about the existence of an armed conflict, ${ }^{42}$ it is submitted that bin Laden's killing did take place in the setting of an armed conflict, albeit one which does not fall neatly into the definition of either an international or noninternational armed conflict. A formal declaration of war is irrelevant when determining whether an armed conflict exists and it is more important to determine whether something more protracted than sporadic acts of violence exists. While the public may only hear of certain attacks against Al-Qaeda, the number of military operations and drone attacks ${ }^{43}$ carried out against suspected Al-Qaeda terrorists, and the attacks against such US troops in response thereto, ${ }^{44}$ certainly fulfils the objective requirement of protracted violence necessary to constitute armed conflict, albeit one which, in the authors' opinion, is not governed by IHL.

Due to the fact that the focus of this article is not so much on the question of legality with regards to bin Laden's killing as it is on the appropriate regime to regulate new age anti-terrorism warfare, this question will be left open.

However, with regards to the legal framework applicable to bin Laden's killing, one cannot apply the principles of IHL to this armed conflict that falls in the gap between international and noninternational armed conflict. Only the broader principles of IHRL may be applied, as the basis for the rules of IHL. Until this growing form of war on the basis of self-defence is sufficiently regulated by $\mathrm{IHL}$ instruments through the possible extension of the definition of noninternational armed conflict, it remains a scenario to be dealt with under IHRL. The constantly-changing nature of warfare makes a discussion such as this absolutely essential in order to ensure that the law governing conduct during war evolves as rapidly as the methods of the combatants. Therefore, while the contemporary form of antiterrorism warfare is not currently regulated by $\mathrm{IHL}$, there is nothing preventing its development to include conflicts of this nature as mentioned above.

In order to create a situation where countries may adequately defend themselves against terrorist onslaught (as advocated by Kretzmer), the very stringent rules of IHRL must be limited in order to be suitable for this form of armed conflict. As it stands, the IHRL provisions protecting the right to life restrict the lawful actions of

42 Milanovic $\mathrm{n} 13$ above.

43 G Miller (2011) 'Increased US drone strikes in Pakistan killing few high-value militants’ 21 February 2011 http://www.washingtonpost.com/wp-dyn/content/ article/2011/02/20/AR2011022002975.html (accessed on 12 September 2011).

44 A Leland \& MJ Oboroceanu (2010) "Congressional Research Service Report for Congress - American War and Military Operations Casualties: Lists and Statistics' (26 February 2010); Report lists 702 hostile deaths and a further 4949 wounded in action in the 'Global war on terror: Operation enduring freedom'. 
countries attempting to defend themselves. This is not, however, a licence for those same states to overstep the boundaries of international law (in particular, IHRL) in order to protect themselves. The death of bin Laden itself, whether or not it is a violation of IHRL, may well catalyse a change in the law with regards to self-defence killings due to the media attention it has drawn to the current shortcomings of IHL. 



\title{
TRANSFORMATIVE CONSTITUTIONALISM: SEPARATE BUT EQUAL? A SCEPTICAL APPROACH
}

\author{
by Ruan du Toit*
}

'The horizon of rights is as limitless as the hopes and expectations of humanity.' - Sachs $\mathrm{J}^{1}$

\section{Transformative constitutionalism}

There is no single coherent definition of transformative constitutionalism. ${ }^{2}$ However, in keeping with the spirit of transformation as set about in the Constitution of the Republic of South Africa (Constitution) some common ground must be ascertained as to the notion of what transformative constitutionalism is. It is quite fair to contend that the Constitution ${ }^{3}$ seeks to heal the wounds of the past. ${ }^{4}$ In doing so, the Constitution ${ }^{5}$ endorses substantive equality rather than formal equality. ${ }^{6}$ The focus shifts toward an equal outcome in a given situation, relative to the unique circumstances in our society, and not a blanket provision blindly setting out means to achieve equality. Former Chief Justice Langa refers to this phenomenon of transformative constitutionalism as a social and economic revolution. ${ }^{7}$ Our Constitutional Court has, as it often does, painted in broad strokes a notion of the ideology of transformative constitutionalism: 8

Ours is a transformative constitution ... Our Constitution provides a mandate, a framework and to some extent a blueprint for the transformation of our society from its racist and unequal past to a society in which all can live with dignity.

From these broad strokes and ideological notions, one can identify the object of transformative constitutionalism in a post-apartheid South African society: a truly equal society, where all decisions must be substantiated by law. ${ }^{9}$

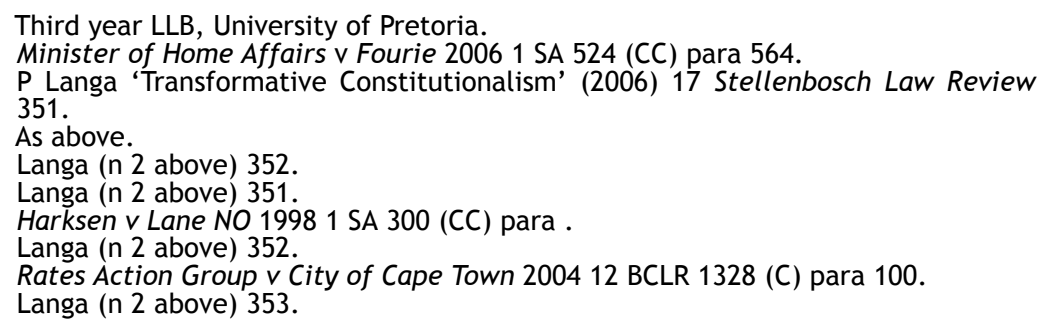


I dare say that I call it, however laudable, a sentimental notion. Van Marle utilises an expression that I treasure - the 'spectacle of post-apartheid transformative constitutionalism'. ${ }^{10}$ She elucidates the fact that if our society cannot acknowledge the limits of the law and human rights, we are doomed to rediscover the ordinary and transformative constitutionalism will have very little or no effect on the ordinary everyday lives of human beings. ${ }^{11}$ If our Constitution ${ }^{12}$ does not have the power to change ordinary lives, it has failed in its objective of transforming our post-apartheid South African society. We must therefore be critical and even sceptic, of our Constitution ${ }^{13}$ and the pedestal upon which human rights is resting. Klare has suggested that a post-liberal reading of our constitution is the correct approach in reading the provisions and values set about therein, for the very reason that it is a post-liberal constitution embodying the most advanced of rights, such as socio economic rights. ${ }^{14}$

A rather curious case resurfaces regarding a post-liberal reading of the Constitution, where the majority of the Constitutional Court (I would most humbly contend) failed to apply the correct reading of the Constitution ${ }^{15}$ and created a backdoor for the legislature to formally discriminate against a category of persons.

What case would my bleeding liberal hart then, as a friend often so kindly phrases it, be aggrieved about? The one atop the shrine of annoyance to many religious and more conservative members of our post-apartheid society:

\section{Minister of Home Affairs v Fourie $e^{16}$}

I believe the lone dissenter in the matter, former Justice O'Regan, applied the correct reading of section 39(2) of the Constitution by using the so-called principle of 'reading in' to create a gender-neutral definition of marriage in the Constitution.

Section 39(2) of the Constitution requires a court to promote the 'spirit, purport and objects' of the Bill of Rights when interpreting legislation or developing the common law. Former Justice O'Regan was in lone dissent regarding the appropriate remedy pertaining to the unconstitutionality of the definition of marriage in the Marriage Act. ${ }^{17}$ She would have had the order with immediate effect and alter

14 KE Klare 'Legal culture and transformative constitutionalism' (1998) South African Journal of Human Rights 146-188.

15 Langa (n 2 above) 351.

16 Fourie (n 1 above).

1725 of 1961. 
the common law definition of marriage, traditionally being the lifelong union of one man and one woman to the exclusion of all others while it lasts, be gender neutral by utilising the so-called principle of 'reading in'. ${ }^{18}$

Instead, the majority of the court gave the legislature time to correct the definition of marriage, and formally discriminate against lesbian, gay, bisexual and transgender persons. The legislature enacted the Civil Union Act. ${ }^{19}$

Under the Civil Union Act, ${ }^{20}$ spouses can elect to have their union known as a marriage or a civil union. ${ }^{21}$ I employ the phrase 'formally discriminate', because for the most part the Civil Union $\mathrm{Act}^{22}$ brings about the same consequences as the Marriage Act. ${ }^{23}$ There however seems to lurk some sense of inferiority in the air about a civil union. Generally, albeit a somewhat anecdotal claim (but has nonetheless become a finding of fact in American law), ${ }^{24}$ society does not regard a civil union as a marriage.

The question arising can be concisely formulated as follows: although a civil union can be registered as a marriage under section 12(3) of the Civil Union Act, ${ }^{25}$ does such registration give rise to the same cultural and traditional symbolic values associated with that of marriage?

\section{The long and winding road}

Coincidentally, a Beatles song by the name of 'The long and winding road ${ }^{26}$ popped into my mind as I deliberated what the next heading in this article might be. It is a rather appropriate metaphor for the road lying ahead regarding transformative constitutionalism, and judicial review. A very wise man that has taught me interpretation of statutes not too long ago, impressed the following upon my mind: very few things in life are final. ${ }^{27}$

In the Fourie case, ${ }^{28}$ the Court emphasised marriage's 'congenial symbolic dimensions as a normative good to which access must be encouraged'. ${ }^{29}$ Yarbrough suggests a consolidationist approach to the

18 See National Coalition of Gay and Lesbian Equality $v$ Minister of Home Affairs 20002 SA 1 (CC) and CJ Botha, Statutory interpretation: An introduction for students (2005) 38.

17 of 2006.

As above.

Sec 12(3).

n 19 above.

n 17 above.

See In re Marriage Cases ( 42 below) and Perry $v$ Schwarzenegger ( $\mathrm{n} 44$ below). n 19 above.

The Beatles 'The long and winding road' from the album Let it be (1970).

Professor CJ Botha.

n 11 above. 
situation in South African matrimonial law. ${ }^{30}$ The author emphasises the harm of symbolic exclusion ${ }^{31}$ in a multicultural post-apartheid society. It would appear that the ideal solution is for the legislature to consolidate the Marriage Act, ${ }^{32}$ Recognition of Customary Marriages $\mathrm{Act}^{33}$ and Civil Union $\mathrm{Act}^{34}$ in a single comprehensive package of family legislation. It would be most ideal for co-habitation relationships lacking official recognition to be addressed in the consolidated marriage legislation as well.

One might speculate that internal cabinet strife could have caused the proliferation of marriage legislation, and has consequently diverted the rail of progress onto the tracks of "separate but equal' 35 in our post-apartheid society.

It would be most fanciful to believe the legislature will consolidate marriage legislation any time soon in the foreseeable future. We have here to do with a category of persons who by all means are entitled to measures of substantive equality pertaining to marriage, but their human dignity, equality and freedom ${ }^{36}$ as fundamental values are undermined by avoiding formal equality. Justice Edwin Cameron elucidates that there has never been a good time to be gay in modern Western society. ${ }^{37}$ I believe we merely have a somewhat more tolerant yet hostile relationship with people living in same-sex unions, or persons who are merely effeminate males or emasculate females. It may even be said that there is a frail and toxic atmosphere of bare tolerance in society towards such persons. We have a golden thread of double standards running through society. What is to be done then? Judicial review. At face value, this might seem ludicrous. Judicial review of what? Proliferated marriage legislation? Yes.

\section{A comparative perspective: it is possible}

In South Africa, the so-called equality provision in the Bill of Rights strongly entrenches the right not to be discriminated against on grounds of sexual orientation. ${ }^{38}$ Mindful of that, my attention had been brought to curious legal proceedings in the United States of

MW Yarbrough 'South Africa's wedding jitters: consolidation, abolition or proliferation’ (2006) 18 Yale Journal of Law and Feminism 498.

Yarbrough (n 29 above) 498.

Yarbrough (n 29 above) 498.

n 13 above.

n 17 above.

n 19 above.

Yarbrough (n 29 above) 506.

Sec $1(a)$ of the Constitution.

E Cameron 'Sexual orientation and the law' (1992) South African Human Rights Yearbook 87.

Sec 9 of the Constitution. 
America. The twitter sphere was buzzing, or we should rather say tweeting - live from the courtroom about the matter throughout the most of 2010.

In the State of California, same-sex marriage had been banned by a constitutional amendment to the State Constitution limiting marriage as a union between only a man and a woman. ${ }^{39}$ This had been done in accordance with electorate law, by means of a statewide referendum called Proposition 8. 40 The state-wide initiative succeeded by the skin of its nose, in a $52 \%$ yes and a $48 \%$ no vote. The State of California has given adequate recognition to domestic partnerships and same-sex co-habitation in terms of the California Family Code since 1998. ${ }^{41}$

The Supreme Court of California ruled domestic partnerships to be inferior to a marriage, although providing all the same material benefits of marriage, and a violation of the right to due process (In re Marriage Cases). ${ }^{42}$ After conservative family value groups were aggrieved by the decision, the initiative to amend the State Constitution had been brought about by Proposition 8. After an unsuccessful challenge in the State Supreme Court, the opponents of Proposition 8 took their battle to Federal Court, contending the State Constitution violated their Fourteenth Amendment right to due process under the Federal Constitution. ${ }^{43}$

\section{The lawfare in Perry $v$ Schwarzenegger 44}

\subsection{The factual matrix}

Miss Perry and Miss Stier, along with Mister Zarrillo and Mister Katami, two same-sex couples that desired to be joined in matrimony, but were subsequently denied marriage licenses on the basis of Proposition 8, sued the Governor (then Arnold Schwarzenegger) and

Proposition 8 amending the California Constitution §। and $\$ 7.5$ subsequently limiting the legal recognition of marriage to opposite-sex couples only.

$J$ Croyle 'Perry $v$ Schwarzenegger, Proposition 8 and the fight for same-sex marriage' (2011) 19 American Journal of Gender, Social Policy \& the Law 426.

Division 2 Part 1 \$297-297.5 defining a domestic partnership under California law and conferring upon domestic partners the same rights and responsibilities as married couples (as set out in the California Family Code \$308.5). For the sake of clarity, it is quite interesting to note that although codification is traditionally synonymous with the civil law, the State of California has a unique set of 29 Codes based on the English law. In essence, therefore, California law is a codified system of English law, and as such is quite an anomaly to the Anglo-American legal tradition (although based thereupon) which is not codified. See http:// www.leginfo.ca.gov/calaw.html (accessed 26 September 2011).

183 P 3d (Cal 2008) 384, 445.

United States Constitution 1789.

704 F Supp 2d (ND Cal 2010) 921, 927-928. 
several other California State officials in their official capacities. ${ }^{45}$ Chief Federal District Court Judge Vaughn Walker (since retired) overturned Proposition 8. The basis for his decision is founded upon the fact that the amendment to the State Constitution violated the opponents of Proposition 8's Fourteenth Amendment Federal Constitutional right to due process and equal protection, ${ }^{46}$ a twofold test in American constitutional law. The state had no legitimate interest in limiting marriage to opposite sex couples. One should be mindful to identify that the so-called anti-interference principle in American constitutional law comes into play, where the state may not interfere with individual liberties unless there is a legitimate governmental interest to do so. The 'rationality principle' was also deployed to conclude that the state had no rational basis for denying marriage licenses to same-sex couples. Despite a possible analogy between the so-called 'equality clause' in section 9 of the South African Constitution and the 'due process' clause of the Fourteenth Amendment to the United States Constitution, much of Perry's case ${ }^{47}$ is irrelevant to the post-apartheid South African context, save for two other crucial aspects.

These two key factors interplaying with South African constitutional law can be identified as follows: domestic partnerships, as civil unions, are inferior to marriages even though they provide all the same material benefits and recognition to same-sex couples as marriage provides for opposite sex couples. Secondly, marriage is a fundamental right. Based on the founding values set out in the South African Constitution: ${ }^{48}$ human dignity, equality and freedom, it can be acknowledged that there is a guarantee to the right of a person to marry the person of his or her choice, this choice encompasses the right to marry another person regardless of their gender. ${ }^{49}$

The basis for much of my argument is founded upon the following extrapolations of fact: in a jurisdiction where the right not to be discriminated against is so much more strongly entrenched ${ }^{50}$ than that of the United States when sexual orientation comes into play, why would a claim that civil unions are derogatory and denying a person the fundamental right to the traditional institution of marriage, rendering a category of persons second class citizens, not succeed?

n 35 above.

Amendment Fourteen to the United States Constitution 1789.

n 35 above.

n 28 above.

n 1 above.

n 39 above. 


\subsection{Marriage is a fundamental right}

The terra firma of the argument of the opponents of Proposition 8 in the Perry case ${ }^{51}$ was based upon the fact that marriage is a fundamental right. In the American context, marriage legislation banning interracial marriages has on often an occasion been overturned on constitutional grounds set about in the Fourteenth Amendment. 52

The Supreme Judicial Court of Massachusetts has succinctly illuminated the matter in its decision that banning same-sex marriage by state legislation is unconstitutional and a violation of the fundamental right to marry. In Goodridge $v$ Department of Public Health, ${ }^{53}$ the court held that withholding people from marriage is to bar them from participation in one of the state's most 'rewarding and cherished institutions,' and accordingly made no distinction between its traditional and same-sex variations in its analysis. ${ }^{54}$

In the South African context, marriage is a fundamental right. ${ }^{55}$ However, the proliferation of marriage legislation has created a category of second class citizens, so-called civil union partners. The state had no rational basis for not merely amending the definition of marriage in the Marriage Act ${ }^{56}$ as a gender-neutral definition. Section 36 of our Constitution, ${ }^{57}$ which is often referred to as the limitation clause, now interplays with the following factual matrix in our South African context. Is the proliferation of marriage legislation, which is a prima facie infringement of a fundamental right, reasonable and justifiable in an open and democratic society, based on human dignity, equality and freedom? ${ }^{58}$ Our Constitutional Court, in $S v$ Makwanyane, ${ }^{59}$ has endorsed a generous approach to interpreting rights with reference to the decision of the Supreme Court of Canada in $R \vee$ Big M Drug Mart. ${ }^{60}$

The substantive equality endorsement of our Constitutional Court as set about in Harksen $v$ Lane $N \mathrm{O}^{61}$ may however hamper this argument. A person is not owed formal equality over substantive equality. This argument has often times resonated in American

n 35 above.

Loving v Virginia 388 US 1, 10-11 (1967).

798 NE 2d 941, 949 (Mass. 2003).

$M$ van Camp 'Perry $v$ Schwarzenegger: A large step in the direction of marriage equality in California' (2011) Law \& Sexuality Review Lesbian Gay Bisexual \& Legal Issues 123.

n 40 above.

n 17 above.

n 12 above.

$\mathrm{Sec} 36(1)$ of the Constitution.

19953 SA 391 (CC).

(1985) 1 SCR 295.

19981 SA 300 (CC). 
constitutional law in a rather curios phrase: a person is not owed fairness over due process.

I believe, however, that the founding values embodied in our Constitution $^{62}$ should trump the substantive equality test when addressing marriage equality. I by no means suggest that substantive equality should be disregarded. It has a most vital role in transformative constitutionalism. A complex interplay of the human dignity, equality and freedom of a specific category of persons with whom the law has a long standing ill relationship, deserve consideration over substantive equality.

\subsection{Civil unions are not marriages}

It has already been reiterated in this paper that civil unions provide all the same material benefits to persons as marriage, and civil union partners can have their civil unions known as a marriage. ${ }^{63}$ However, the fundamental right to marry eludes civil union partners, and a sense of inferiority lurks about in the air. The position regarding civil unions in South Africa is very much ancillary to the position of domestic partnerships in the State of California at the time litigation proceedings in the Perry case ${ }^{64}$ began. In terms of California law, domestic partnerships provide all the same material benefits to domestic partners as a marriage. ${ }^{65}$ Judge Walker exposed the scenario in the Perry decision as such: 66

The availability of a domestic partnership does not provide gays and lesbians with a status equivalent to marriage because the cultural meaning of marriage and its associated benefits are intentionally withheld from same-sex couples in domestic partnerships.

The decision of Judge Walker is pending appeal from the Ninth Circuit Federal Court of Appeals, and the long term outcome of the decision is still somewhat precarious. ${ }^{67}$

The proliferation of marriage legislation in California is minute in comparison to South African matrimonial law. The provisions governing marriages and domestic partnerships in California are governed by two different parts of the Family Code. ${ }^{68}$ They are to be found in one and the same body of legislation. The domestic

62 n 39 above

63 Sec 12(3) Act 17 of 2006.

64 n 40 above.

65 California Family Code $\$ 297.5(\mathrm{~d})$ : 'The rights and obligations of registered domestic partners with respect to a child of either of them shall be the same as those of spouses.' Also see Elisa B v Superior Court 117 P3d (Cal 2005) 660, 670 where it was held that under the Uniform Parentage Act, a person may have two parents of the same sex in California.

$66704 \mathrm{~F}$ Supp 2d para 54.

67 Perry $v$ Schwarzenegger, No 10-16696 (9th Cir Aug 16, 2010).

68 n 53 above. 
partnership provision however does not provide domestic partners the option of having their partnership know as a marriage, as civil union partners in South Africa have. The South African law is nonetheless, still a proliferation of marriage legislation impeding the basic human rights of lesbians, gays, bisexuals and transgender persons to marry.

\section{Conclusion}

One might ask what more is necessary than adequate legal recognition of same-sex unions? We provide all the material benefits to such persons. The answer is unequivocal - human dignity. These categories of persons have had a prolonged suffering by means of victimisation and discrimination in the past and, in the spirit and purport of human rights, at the very least deserve to be beneficiaries of transformative constitutionalism. A complex myriad of factors come into play in a post-apartheid South African society when one approaches transformative constitutionalism. Conservative religious groups, the state, and victims of discrimination have competing interests. Ultimately the judiciary needs to protect constitutionally entrenched rights of minority groups when adjudicating such matters.

If an aggrieved party feels a civil union is not a marriage in the traditionally associated context thereof, and another aggrieved party perceives it an interest of his or hers to oppose such interest - the court has an obligation to protect the interest of minorities. If the approach of former Justice O'Regan had simply been followed in the Fourie case, ${ }^{69}$ there would not be any second class citizens being discriminated against under marriage legislation. Most respectfully said, instances arise where the judiciary needs to remove its gloves, and exceed its bounds where it is practical and necessary. If the legislature does not consolidate its marriage legislation, the judiciary should ideally respond by taking to the demeanour of: 'Then so be it, let us do it for you.'

My legal studies, and very particularly a course in Jurisprudence, have remoulded my mind in a rather eloquent manner. Emanating from a conservative background, the law has changed my perspective on the world and everyday life.

The problems in the world and the everyday life of every human being, in the de facto context thereof, cannot be resolved by the law. The law has limits. As soon as we can identify and acknowledge the limits of the law, we can purport to bring about change. In an ideal world, the law de jure is interwoven with the law de facto. Postapartheid South Africa is not Utopia. It is nonetheless not a reason for us not to strive thereto - and to better the everyday lives of human 
beings by acknowledging the limits of the law and human rights to bring about change.

To the person that may contend that my argument is outrageous or atrocious, I leave with the following quote of United States Supreme Court Justice Kennedy in Lawrence $v$ Texas: ${ }^{70}$ 'Our obligation is to define the liberty of all, not to mandate our own moral code.' 505 US 833, 850 (1992). 


\title{
STOP THE BEACH RENOURISHMENT, INC. $v$ FLORIDA DEPARTMENT OF ENVIRONMENTAL PROTECTION: AN AVULSION OF LITTORAL RIGHTS
}

\author{
by Jeffrey Partlow*
}

\section{Introduction}

A land being littoral ${ }^{1}$ 'often constitutes its chief value and desirability. ${ }^{2}$ In many cases, the littoral

rights incident to the ownership of the land were the principal, if not sole, inducement leading to its purchase ... and the reason for the price charged by the seller. ${ }^{3}$

Florida has 2276 miles of tidal shoreline, ${ }^{4} 1197$ miles of coastline, ${ }^{5}$ and 825 miles of beaches. ${ }^{6}$ The state is home to over 18.8 million people, ${ }^{7}$ attracts approximately 80 million visitors each year, ${ }^{8}$ and has a population density of more than four times the national average. ${ }^{9}$ Based on these facts and the premium often paid for beach front property, it is easy to see why defining littoral rights is vital to both the Florida economy and people who own land abutting navigable waters. It is also easy to understand why so many disputes

* Third year JD student, Capital University Law School, Columbus, Ohio, USA.

The term 'littoral owner' refers to the ownership of property abutting a 'coast or shore of an ocean, sea, or lake.' B Garner Black's law dictionary (2009) 1018; Bd of Trustees of the Internal Improvement Trust Fund v Sand Key Assocs, Ltd, 512 So. 2d 934936 (Fla. 1987). The term 'riparian owner' refers to the ownership of property along the bank of a river or stream. Garner (n 1 above) 1441; Sand Key 512 So. $2 d$ 936. 'Cases and statutes, however, have used 'riparian owner' broadly to describe all waterfront owners.' Sand Key 512 So. 2d 936. This note specifically addresses the rights of littoral owners and will use the term 'littoral' whenever possible.

2 Thiesen v Gulf la. \& Ala. Ry. Co 78 So 491507 (Fla. 1918).

3 Thiesen 78 So. 491507.

$4 \quad$ M Kilbourn \& HM Hujsa The Florida domicile handbook: vital information for new Florida residents (2009) 112.

5 B Brooke The everything guide to coastal Florida (2007) 20.

6 See Florida Department of Environmental Protection, "Florida shoreline length information according to beaches and shores technical and design memorandum 89 - 1, 5th Edition, December 1993, entitled beach conditions in Florida: a statewide inventory and identification of the beach erosion problem areas in Florida by Ralph R. Clark' (2012) 1, available at http://www.dep.state.fl.us/ beaches/publications/pdf/fl_beach.pdf.

7 US Census Bureau '2010 Census Data' http://quickfacts.census.gov/qfd/states/ 12000.html (accessed 23 January 2011).

8 'Oil aside, Florida holds its own in tourism' Sarasota Herald-Tribune 25 August 2010 D1.

9 US Census Bureau (n 7 above). 
have arisen between littoral property owners and the state, ${ }^{10}$ which owns the land under navigable waters below the mean high-water line. ${ }^{11}$

Historically, littoral property owners in Florida have had a vested right to accretions, ${ }^{12}$ subject to the doctrine of avulsion. ${ }^{13}$ Florida's Beach and Shore Preservation Act provides for elimination of this vested right without the occurrence of an avulsive event or any other event that would justify its elimination. ${ }^{14}$ Specifically, the Act authorises and provides procedures for the restoration of beaches determined critically eroded by the Florida Department of Environmental Protection (the 'Department'). ${ }^{15}$ When a beach restoration project is undertaken by the state, the Act eliminates the littoral owner's right to accretions upon the state setting and recording an erosion control line. ${ }^{16}$

In Stop the Beach Renourishment, Inc. $v$ Florida Department of Environmental Protection, ${ }^{17}$ the United States Supreme Court upheld Florida's Beach and Shore Preservation Act against a facial constitutional challenge. ${ }^{18}$ The Court held that the Act's elimination of the right to accretions does not constitute a taking because littoral owners' right to accretions is inferior to the state's right to fill. ${ }^{19}$ In erroneously upholding the Act, the Court miscategorised the background principles of Florida property law and contributed to the continued erosion of littoral rights in Florida. Considering that 398.6 miles of beaches were considered critically eroded in June $2011,{ }^{20} \mathrm{a}$ significant portion of littoral owners in Florida are now in jeopardy of

See 'Beaches a major playground for controversy' Sarasota Herald-Tribune 13 March 2010. Similar disputes over the rights of littoral property owners have arisen in states throughout the country. See, eg, City of New York $v$ Realty Assocs., 176 NE 171 (N.Y. 1931); Fowler v Wood, 85 P. 763 (Kan. 1906).

11 Fla. Const. art. X, § 11

12 'Accretion is the gradual and imperceptible addition of soil to the shore of waterfront property.' Bd. of Trs. of the Internal Improvement Tr. Fund v Medeira Beach Nominee, Inc., 272 So. 2d 209211 (Fla. Dist. Ct. App. 1973). A 'gradual and imperceptible' change is one where 'witnesses may see from time to time that progress has been made, [however,] they could not perceive it while the process was going on.' St. Clair Cnty. v Lovingston, 90 US (23 Wall.) 4668 (1874). 'Reliction' or 'dereliction' is an increase of the land by a gradual and imperceptible withdrawal of any body of water.' $B d$. of Trs. of the Internal Improvement Tr. Fund v Sand Key Assocs., Ltd., 512 So. 2d 934936 (Fla. 1987). For purposes of this note, the term 'accretions' will be used to refer to accretion, reliction, and dereliction, and the processes in which each occurs.

13 See part 3.2 Littoral owners have a vested right to accretions below. Avulsion is the opposite of accretion; Lovingston 90 US (23 Wall.) 68; it 'is the sudden or perceptible loss of or addition to land by the action of the water or a sudden change in the bed of a lake or the course of a stream.' Sand Key 512 So. $2 \mathrm{~d} 936$.

14 See Fla. Stat. § 161.011-161.45 (2010); parts 2.2 \& 3.3 below.

15 See part 2.2 below.

16 See part 2.2 below.

17 Stop the Beach Renourishment, Inc. $v$ Florida Department of Environmental Protection $130 \mathrm{~S}$. Ct. 2592 (2010).

18 See Stop the Beach Renourishment 130 S. Ct. 2610-13 \& n 11-12.

19 Stop the Beach Renourishment 130 S. Ct. 2610-13. 
losing the right to accretions, ${ }^{21}$ a right that for hundreds of years has been considered a vested right. ${ }^{22}$ The problem at issue may have best been described by a Florida court in 1965: ${ }^{23}$

Florida is bordered by water on the east, south and west. The numerous islands or keys are constantly changing by various methods of accretion, alluvion, erosion, reliction and avulsion, giving rise to myriad problems. Public policy demands a definite standard of quieting title to these areas.

Public policy also demands that the right to accretions continue to be categorised as a vested right that cannot be arbitrarily taken without the occurrence of a justifying avulsive event or the government paying just compensation.

This note analyses the United States Supreme Court's decision in Stop the Beach Renourishment, Inc. $v$ Florida Department of Environmental Protection. This note focuses on whether the Beach and Shore Preservation Act constitutes an unconstitutional taking of littoral owners' right to accretions through authorisation of beach restoration projects. ${ }^{24}$ Part II of this note provides background information on littoral rights, the Beach and Shore Preservation Act, and the Court's decision in Stop the Beach Renourishment, Inc. $v$ Florida Department of Environmental Protection.

Part III analyses the Court's decision and concludes with a finding that the Beach and Shore Preservation Act constitutes an unconstitutional taking of littoral owners' vested right to accretions. After a careful analysis of the three main cases relied on in the Court's decision, the real background principles of Florida property law come to light; the state does not have a right to fill sovereign submerged lands adjacent to littoral property it does not own, and littoral property owners have a vested right to accretions. This vested right to accretions is found not only in common law but in the Florida Constitution and in Florida Statutes. By setting a fixed erosion control line as the boundary between private and sovereign lands, the Act unconstitutionally eliminates the littoral owners' vested right to accretions without the occurrence of a justifying avulsive event.

The purpose of this article is to stress that the Florida Supreme Court and the United States Supreme Court severely misinterpreted

20 Bureau of Beaches and Coastal Systems, 'Critically Eroded Beaches in Florida' (June 2011) 12, available at http://www.dep.state.fl.us/beaches/publications/ pdf/CritEroRpt7-11.pdf.

See part 2.2 below.

See part 2.1 below.

Ford v Turner 142 So. 2d 335342 (Fla. Dist. Ct. App. 1962).

Notwithstanding its unanimous decision to uphold the Beach and Shore Preservation Act, the Court was otherwise highly fractured. See Stop the Beach Renourishment $130 \mathrm{~S}$. Ct. 2597. A majority of the Court's analysis focuses on what test applies to judicial takings and whether the Florida Supreme Court's decision effected a judicial taking. See Stop the Beach Renourishment $130 \mathrm{~S}$. Ct. 2592. 
Florida property law. I am compelled, based on my conclusions regarding the underlying property law, to state that the Supreme Court should have resolved the judicial takings issue. My interest, however, is in water law and showing that two important courts made a fundamental mistake in categorising the underlying property law. Judicial takings are an issue in this case, but many other scholars have discussed $i^{25}$ and I reserve the issue for another day.

\section{Background}

\subsection{Littoral rights}

[L]ittoral rights are legal rights and, for constitutional purposes, the common law rights of ... littoral owners constitute property. ${ }^{26}$ Although they may be regulated, littoral rights 'may not be taken without just compensation and due process of law. ${ }^{27}$

Such rights include, among other things, "the right to use the water shared by the public,' and

the following vested rights: (1) the right of access to the water, including the right to have the property's contact with the water remain intact; (2) the right to use the water for navigational purposes; (3) the right to an unobstructed view of the water; and (4) the right to receive accretions and relictions to the property. ${ }^{28}$

These rights are in addition to traditional property rights such as the right to possess, use, and dispose. ${ }^{29}$

The littoral owner's common law right to accretions is deeply rooted in American and English law. ${ }^{30}$ Blackstone set forth the common law rule and rationale for the doctrine of accretion (alluvion) and avulsion:

And as to lands gained from the sea, either by alluvion, by the washing up of land and earth, so as in time to make terra firma, or by

See eg $M$ Blumm \& E Dawson 'The Florida beach case and the road to judicial takings' (2011) 35 William \& Mary Environmental Law \& Policy Review 713; DB Barros 'The complexities of judicial takings' (2011) 45 University of Richmond Law Review 903; T Mulvaney 'The new judicial takings construct' (2011) 120 Yale Law Journal Online 247; RT Thomas 'Of woodchucks and prune yards: a view of judicial takings from the trenches’ (2010) 35 Vermont Law Review 437 437-39. Bd. of Trs. of the Internal Improvement Tr. Fund $v$ Sand Key Assocs., Ltd., 512 So. 2d 934936 (Fla. 1987) (citing Hayes v Bowman 91 So. 2d 795 (Fla. 1957); Brickell v Trammell 82 So. 221 (Fla. 1919); Thiesen v Gulf, Fla. \& Ala. Ry. Co., 78 So. 491 (Fla. 1918); Feller v Eau Gallie Yacht Basin, Inc., 397 So. 2d 1155 (Fla. Dist. Ct. App. 1981)).

27 Brickell 82 So. 227

28 Sand Key 512 So. 2d 936 (citing Hughes v Washington 389 US 290 (1967); St. Clair Cnty. v Lovingston 90 US (23 Wall.) 46 (1874); Bowman 91 So. 2d 795; Brickell 82 So. 221; Thiesen 78 So. 491) (emphasis added).

29 See Loretto $v$ Teleprompter Manhattan CATV Corp., 458 US 419 435-36 (1982).

30 See text accompanying $n$ 31-36 below. 
dereliction, as when the sea shrinks below the usual water-marks; in these cases the law is held to be that if the gain be by little and little, by small and imperceptible degrees, it shall go to the owner of the land adjoining. For de minimis non curat lex; and besides, these owners being often losers by the breaking in of the sea, or at charges to keep it out, this possible gain is, therefore, a reciprocal consideration for such possible charge or loss. But if the alluvion be sudden or considerable, in this case it belongs to the king; for, as the king is lord of the sea, and so owner of the soil while it is covered with water, it is but reasonable he should have the soil when the water has left it dry. ${ }^{31}$

The common law rule of accretion set forth by Blackstone has gone without significant change and has been adopted by the United States Supreme Court. ${ }^{32}$ The Court has continually reaffirmed in '[a] long and unbroken line of decisions' that littoral owners have a vested right to accretions. ${ }^{33}$ In 1865, Supreme Court Chief Justice Taney stated that

[a]most all jurists ... both ancient and modern, have agreed that the owner of the land ... bounded [by the sea], is entitled to these additions. ${ }^{34}$

Florida has also adopted the common law rule that littoral owners have a vested right to accretions. ${ }^{35}$ In doing so, Florida courts have adopted four rationale behind the doctrine of accretion:

(1) De minimis non curat lex; (2) he who sustains the burden of losses and of repairs imposed by the contiguity of waters ought to receive whatever benefits they may bring by accretion; (3) it is in the interest of the community that all land have an owner and, for convenience, the riparian is the chosen one; (4) the necessity for preserving the riparian right of access to the water. ${ }^{36}$

Florida's rationale are derived from Blackstone's and have also gone without significant change since Blackstone set forth the rule. ${ }^{37}$

312 W Blackstone Commentaries (1766) 261-62.

32 Hughes 389 US 293-94; Lovingston 90 US (23 Wall.) 68-69; Banks v Ogden 69 US (2 Wall.) 5767 (1864)

33 Hughes 389 US 293-94 ("A long and unbroken line of decisions of this Court establishes that the grantee of land bounded by a body of navigable water acquires a right to any natural and gradual accretion formed along the shore.'); accord Lovingston 90 US (23 Wall.) 68-69 ([The littoral owner's right to accretions] is an inherent and essential attribute of the original property. The title to the increment rests in the law of nature. It is the same with that of the owner of a tree to its fruits, and of the owner of flocks and herds, to their natural increase. The right is a natural, not a civil one.). Banks 69 US 67.

35 See Bd. of Trs. of the Internal Improvement Tr. Fund v Sand Key Assocs., Ltd., 512 So. 2d 934936 (Fla. 1987); see also State v Fla. Nat'l Props., Inc., 338 So. 2d 13 18 (Fla. 1976); Ford v Turner 142 So. 2d 335340 (Fla. Dist. Ct. App. 1962); Mex. Beach Corp. v St. Joe Paper Co., 97 So. 2d 708710 (Fla. Dist. Ct. App. 1957).

36 Bd. of Trs. of the Internal Improvement Tr. Fund v Medeira Beach Nominee, Inc. 272 So. 2d 209 212-13 (Fla. Dist. Ct. App. 1973) (citing Lovingston 90 US (23 Wall.) 67).

37 Compare Lovingston 90 US (23 Wall.) 67-68, and Medeira Beach 272 So. 2d 212-13 with Blackstone (n 31 above) 261-62. 
Courts have noted two significant exceptions to the general principle that littoral owners are entitled to additions of land caused by accretions: (1) 'accretion does not belong to the riparian owner where the riparian himself causes the accretion;' 38 and (2) according to common law, in the case of an avulsive event, the boundary line between sovereign and private property remains unchanged. ${ }^{39}$ If neither exception applies, the '[t]itle to accreted lands ... vests in the riparian owners of abutting lands. 40

\section{Avulsion is the opposite of accretion; ${ }^{41}$}

it is the sudden or perceptible loss of or addition to land by the action of the water or a sudden change in the bed of a lake or the course of a stream. 42

With an avulsive event, the boundary between sovereign submerged lands and private littoral lands normally remains unchanged as the mean high-water line. ${ }^{43}$ This is true regardless of whether the avulsive event exposes previously submerged lands or submerges previous exposed lands. ${ }^{44}$ After an avulsive event, the affected owner is afforded a reasonable time to reclaim the land lost as a result of the avulsive event. ${ }^{45}$

\subsubsection{The Beach and Shore Preservation Act}

In 1961, Florida's Legislature enacted the Beach and Shore Preservation Act. ${ }^{46}$ The Legislature declared it a 'necessary governmental responsibility to properly manage and protect Florida

38 Medeira Beach 272 So. 2d 212 (citing Brundage v Knox 279 Ill. 450 (Ill. 1917); State v Sause 217 Or. 52 (Or. 1959)); accord Sand Key 512 So. 2d 938. In such cases, title to the accreted lands remains with the owner of the previously submerged soi - usually the government. Medeira Beach 272 So. $2 d 212$. The Maderia Beach court noted that: land below the ordinary high water mark is sovereignty land of the state, [and] to permit the riparian owner to cause accretion himself would be tantamount to allowing him to take state land.

As shown in Medeira Beach, the upland owner is entitled to artificial accretions when the owner of the submerged land causes the accretions. Medeira Beach 272 So. $2 d$ 211-12 214-15. The court explained that '[w]ere the state to gain title to this accreted land we believe that riparian titles around the state would be in jeopardy of unmarketability.' Medeira Beach 272 So. 2d 213.

39 See Sand Key 512 So. $2 d 937$.

40 Medeira Beach 272 So. 2d 211-12 (citing Brickell v Trammell 82 So. 221 (Fla. 1919); Mex. Beach Corp., 97 So. 2d 710).

41 Lovingston 90 US (23 Wall.) 68.

42 Sand Key 512 So. 2 d 936.

43 See Sand Key 512 So. 2d 937; see also Bryant v Peppe 238 So. 2d 836 838-39 (Fla. 1970).

44 Sand Key 512 So. 2d 937; see also Bryant 238 So. 2d 838-39.

45 See State v Fla. Nat'l Props., Inc., 338 So. 2d 13 16-18 (Fla. 1976); see also 1 HP Farnham 'The law of waters and water rights' (1904) $\$ 74$ ('If a portion of the land of the riparian owner is suddenly engulfed, and the former boundary can be determined or the land reclaimed within a reasonable time, he does not lose his title to it.'); contra City of Chicago v Ward 169 Ill. 392 (Ill. 1897). 
beaches' because 'beach erosion is a serious menace to the economy and general welfare of the people of [Florida] ... and has advanced to emergency proportions. ${ }^{47}$ The Act establishes procedures for beach restoration 48 and beach nourishment ${ }^{49}$ of 'critically eroded shoreline. ${ }^{50}$ It gives the Department of Environmental Protection the authority to determine which beaches are critically eroded and to 'authorise appropriations to pay up to 75 percent of the actual costs for restoring and nourishing' such beaches. ${ }^{51}$ Local governments apply for funding and must establish a 'mean high water [line] for the area to be restored. 52

Once a beach restoration or nourishment project is determined to be undertaken, a survey of the shoreline is conducted to establish an erosion control line ('ECL'). ${ }^{53}$ In establishing an ECL, the Board of Trustees of the Internal Improvement Trust Fund (the 'Board') 54 is 'guided by the existing line of mean high water.' 55 The Board should consider

the requirements of proper engineering in the beach restoration project, the extent to which erosion or avulsion has occurred, and the need to protect existing ownership of as much upland as is reasonably possible. ${ }^{56}$

Even so, the Board has the authority to set the ECL landward, seaward, or on the mean high-water line. ${ }^{57}$ Once set, the Board records the ECL in the county real property records, 58 and the fixed $E C L$ replaces the mean high-water line as the boundary between sovereign and private lands. ${ }^{59}$ The upland property owner 'continue[s] to be entitled to all common-law riparian rights;' 60 however, the Act eliminates the upland owner's common law right to

47 Fla. Stat. § 161.088 (2010).

48 "Beach restoration" means the placement of sand on an eroded beach for the purposes of restoring it as a recreational beach and providing storm protection for upland properties.' Fla. Stat. § 161.021 (2010).

"Beach nourishment" means the maintenance of a restored beach by the replacement of sand.' Fla. Stat. § 161.021(3) (2010).

50 Fla. Stat. § 161.088 (2010) ('[S]uch beach restoration and nourishment projects ... must be in an area designated as critically eroded shoreline, or benefit an adjacent critically eroded shoreline ...').

51 Fla. Stat. § 161.101(1) (2010)

52 Fla. Stat. §§ 161.101(1), 161.141 (2010).

53 Fla. Stat. § 161.161(3)-(5) (2010).

54 'Board of trustees' is defined as 'the Board of Trustees of the Internal Improvement Trust Fund.' Fla. Stat. § 161.021(5) (2010).

Fla. Stat. § 161.161(5) (2010).

Fla. Stat. \$ $161.161(5)(2010)$

See Fla. Stat. § 161.161(5) (2010).

Fla. Stat. § $161.181(2010)$.

See Fla. Stat. § 161.191 (2010).

Fla. Stat. § 161.201 (2010). Additionally, 'the state shall not allow any structure to be erected upon lands created ... seaward of any erosion control line.' Fla. Stat. § 161.201 (2010). 
accretions. ${ }^{61}$ The ECL can be cancelled if the 'governmental agency charged with the responsibility of maintaining the protected beach fails to maintain the same and as a result thereof the shoreline gradually recedes to a point or points landward of the erosion control line. ${ }^{\prime 62}$

If an authorised beach restoration, beach nourishment, and erosion control project cannot reasonably be accomplished without the taking of private property, the taking must be made by the requesting authority by eminent domain proceedings. ${ }^{63}$

Additionally, when the government conducts restoration and nourishment activities on sovereign submerged lands that would 'unreasonably infringe on riparian rights,' the government must show '[s]atisfactory evidence of sufficient upland interest' adjacent to the riparian land. 64

\subsubsection{Stop the Beach Renourishment, Inc. $v$ Florida Department of Environmental Protection}

In July 2003 after a series of hurricanes, the city of Destin and Walton County, Florida, applied for a permit to use sovereign submerged lands in a project to restore beaches that had been designated 'critically eroded' by the Florida Department of Environmental Protection. ${ }^{65}$ The project proposed to restore 6.9 miles of beach by dredging sand and adding approximately ' 75 feet of dry sand seaward of the mean high-water line.' 66 A coastline survey was completed to determine the mean high-water line, and the Board set an erosion control line on the mean high-water line. ${ }^{67}$ 'Pursuant to section 161.191(1) of the Beach and Shore Preservation Act, this ECL became the boundary between publicly owned land and privately owned upland after it was recorded. ${ }^{, 68}$

'Stop the Beach Renourishment, Inc.', ('Petitioner') - a nonprofit corporation formed by six owners of beachfront property bordering the project area-challenged the project. ${ }^{69}$ In June 2005, after an

61 increase or decrease the proportions of any upland property lying landward of such line, either by accretion or erosion or by any other natural or artificial process.').

62 Fla. Stat. § 161.211 (2010).

63 Fla. Stat. § $161.141(2010)$.

64 Fla. Admin. Code r. 18-21.004(3)(a), (b) (2010).

65 Save Our Beaches, Inc. v Fla. Dep't of Envtl. Prot., 27 So. $3 d 4850$ (Fla. Dist. Ct. App. 2006); Walton Cnty. $v$ Stop the Beach Renourishment, Inc., 998 So. 2d 1102 1106 (Fla. 2008).

66 Stop the Beach Renourishment, Inc. v Fla. Dep't of Envtl. Prot., 130 S. Ct. 2592 2594 (2010).

67 Walton Cnty. 998 So. 2d 1106; Save Our Beaches 27 So. 3d 59.

68 Walton Cnty., 998 So. 2 d 1106.

69 Walton Cnty., 998 So. 2d 1106. Each of the six members owned property to the mean high-water line. Save Our Beaches 27 So. 3d 59. 
unsuccessful administrative challenge by Petitioner, the Department issued a permit authorising use of sovereign submerged lands for the project. ${ }^{70}$ Petitioner subsequently brought suit, and the First District Court of Appeal of Florida determined the Act unconstitutionally eliminated Petitioner's littoral 'rights to (i) receive accretions and relictions to the property, and (ii) have the property's contact with the water remain intact. 71 The district court also certified to the Supreme Court of Florida the following question, as rephrased by the Florida Supreme Court: 'On its face, does the Beach and Shore Preservation Act unconstitutionally deprive upland owners of littoral rights without just compensation?"72

The Florida Supreme Court answered the question in the negative ${ }^{73}$ and held that the doctrine of avulsion permitted the State to restore beaches and set a fixed boundary line between sovereign and private lands. ${ }^{74}$ The court also described the right to accretions as a future contingent interest not implicated by the Act and held there is no littoral right to contact the water. ${ }^{75}$ The Petitioner's request for rehearing was denied ${ }^{76}$ and the United States Supreme Court granted certiorari. ${ }^{77}$

In an otherwise highly fractioned opinion that focused on judicial takings, ${ }^{78}$ a unanimous Court upheld the Beach and Shore Preservation Act as facially constitutional in a Fifth Amendment takings challenge. ${ }^{79}$ The Court determined that the background principles of Florida property law

allowed the State to fill in its own seabed, and the resulting sudden exposure of previously submerged land was treated like an avulsion for purposes of ownership. The right to accretions was therefore subordinate to the State's right to fill. ${ }^{80}$

Save Our Beaches 27 So. 3d 51.

Save Our Beaches 27 So. 3d 57-58.

Walton Cnty., 998 So. 2d 1105 (footnotes omitted).

Walton Cnty., 998 So. 2d 1105.

Walton Cnty., 998 So. 2d 1116-18.

Walton Cnty., 998 So. 2d 1118-20.

Walton Cnty., 998 So. 2d 1102.

Stop the Beach Renourishment, Inc. v Florida Dept. of Environmental Protection 130 S. Ct. 2592 (2010).

78 Stop the Beach Renourishment 130 S. Ct. 25922597.

79 See Stop the Beach Renourishment $130 \mathrm{~S}$. Ct. 2610-13 \& $\mathrm{n} 11-12$. The majority of the Court's opinion focuses on the appropriate test for judicial takings and whether, by upholding the beach restoration act, the Florida Supreme Court effectuated a judicial taking of Petitioner's right to accretions and to contact with the water. See Stop the Beach Renourishment, 130 S. Ct. 2592. 


\section{Analysis}

\subsection{The state of Florida does not have the right to fill sovereign submerged lands adjacent to littoral property it does not own}

In discussing the background principles of Florida property law, the United States Supreme Court improperly relies on three cases to establish that the right to accretions is subordinate to the state's right to fill. ${ }^{81}$ A close evaluation of these cases indicates that the State of Florida does not have the right to fill sovereign submerged lands adjacent to littoral property it does not own. Each case will be discussed in turn.

\subsubsection{Hayes $v$ Bowman}

The United States Supreme Court cites Hayes $v$ Bowman ${ }^{82}$ for the proposition that the state has the right to fill; 83 however, the right to fill was not at issue in that case. ${ }^{84}$ Bowman was about the right to an unobstructed view of the water, and the court in that case set forth a specific rule addressing the right to view. ${ }^{85}$ Bowman does provide a general rule about the right to fill; upland owners can fill submerged land abutting their property when they have title to such land and are authorised by statute to fill such land. ${ }^{86}$

In Bowman, both the appellant and appellee owned littoral property on the 'Channel of the Bay' such that their boundary lines did not run perpendicular to either the channel cut or the shore. ${ }^{87}$ The appellees acquired submerged land adjacent to their property from the Trustees of the Internal Improvement Fund and proposed to fill such land. ${ }^{88}$ The dispute concerned what area littoral owners were entitled to view based on their boundary lines in relation to the shore

81 the Beach Renourishment 130 S. Ct. 2611 (citing Hayes $v$ Bowman 91 So. $2 \mathrm{~d}$ 795 799-800 (Fla. 1957); State ex rel. Buford v City of Tampa 102 So. 336341 (Fla. 1924); Thiesen v Gulf, Fla. \& Ala. Ry. Co., 78 So. 491 501-03 507 (Fla. 1918)).

82 Hayes $v$ Bowman 91 So. 2d 795 (Fla. 1957).

83 Stop the Beach Renourishment $130 \mathrm{~S}$. Ct. 2611 (citing Bowman 91 So. 2d 799-800).

84 See Bowman 91 So. 2 d 801.

85 See Bowman 91 So. $2 \mathrm{~d} 801$.

86 See Bowman 91 So. 2d 797-802.

87 Bowman 91 So. 2 d 798.

88 Bowman 91 So. $2 \mathrm{~d} 800$. 'The submerged lands acquired by appellees for purposes of the proposed fill were purchased under' chapter 26776, Florida Statutes section 253.12 (1951). Bowman 91 So. 2d 800. Under that section, 'title to all sovereignty lands (except in Dade and Palm Beach counties) was vested in the Trustees of the Internal Improvement Fund with power of disposition thereof in the manner provided by the statute.'

Today, Florida Statutes section 253.12 permits the Board of Trustees of the 
and channel cut. ${ }^{89}$ The court recognised the right to 'a direct, unobstructed view of the Channel' and prescribed a rule preserving that right. 90

Not only was the dispute over the right to view and not the right to fill, ${ }^{91}$ but under Florida Statutes chapter 271 (more commonly known as the Butler Bill), littoral owners already had a statutory right to fill submerged lands adjacent to their property. ${ }^{92}$ For Bowman or any case to properly support the Supreme Court's position, the state would have to fill, or convey the right to fill, to a private party having no relation to the littoral uplands. In Bowman, the state conveyed the right to fill to a private party; however, the private party owned the adjacent upland property and only received the right to fill land adjacent to that property. ${ }^{93}$ Therefore, the state did not convey the right to a party without an upland interest or having no relation to the land. Since no third party was involved and the upland owner already had the right to fill, the conveyance did not infringe on the littoral rights of any third party.

Bowman cannot support the proposition that the state has the right to fill because the state did not convey the right to a party without an upland interest or having no relation to the land. In Bowman, the upland owner purchased the submerged lands adjacent to his property and he was authorised by statute to fill such land. ${ }^{94}$ Since no third party was implicated, Bowman stands for the general rule that littoral owners can fill submerged lands abutting their littoral property when they have title to such lands and are authorised

Internal Improvement Trust Fund to sell and convey 'sovereignty tidal and submerged bottom lands;' Fla. Stat. § 253.12(1) (2010); however, when objections are filed, the Board cannot '[i]nterfere with the lawful rights granted riparian owners.' Fla. Stat. § 253.12 (4)(b) (2010). Additionally, the Board can only sell sovereign lands 'lying between the ordinary mean high-water line and any bulkhead line' to 'the upland riparian owner and to no other person, firm, or corporation.' Fla. Stat. § 253.12(4)(e) (2010).

89 Bowman 91 So. $2 \mathrm{~d} 801$ (Appellants claim that they are entitled to an unobstructed view toward the Channel over a corridor measured by extending their northeasterly-southwesterly lot lines directly to the Channel. Appellees claim that this corridor is to be bounded by imaginary lines drawn at right angles from the thread of the Channel to the corners of appellants' lot.).

90 Bowman 91 So. 2d 802 (recognising a right to view 'over an area 'as near as practicable' in the direction of the Channel so as to distribute equitably the submerged lands between the upland and the Channel[, considering] ... the lay of the upland shore line, the direction of the Channel and the co-relative rights of adjoining upland owners').

91 The parties in Bowman both owned lots in a subdivision that was built by dredging and filling in the seabed; Bowman 91 So. 2d 797-98; therefore, it is unlikely that either party thought the right to fill was at issue.

92 Bowman 91 So. 2d 800. The Butler Bill, Fla. Stat. ch. 8537 (1921), provisionally granted littoral owners whose lands extended to the high-water mark, the right to 'dredge, bulkhead, and fill in front of his land to the edge of the channel.' Bowman 91 So. 2d 800; see also RH Hunt 'Riparian rights in Florida' (1955) 8 University of Florida Law Review 393393 398-99.

93 Bowman 91 So. 2d 800.

94 Bowman 91 So. 2d 797-802. 
by statute to fill such lands. ${ }^{95}$ Additionally, when the state owns submerged lands it can convey such lands to the upland property owner. 96

\subsubsection{State ex rel. Buford $v$ City of Tampa}

The Court also cites State ex rel. Buford $v$ City of Tampa ${ }^{97}$ for the proposition that the state has the right to fill. ${ }^{98}$ In Buford, the City of Tampa contracted to sell a significant section of submerged lands to D.P. Davis, a private citizen. ${ }^{99}$ The Florida Attorney General challenged the contract and sought to have Davis and the City of Tampa enjoined from carrying out the contract. 100

The Buford court first noted that the Florida state constitution did not forbid the Legislature from conveying sovereign submerged lands lying between the high and low water mark. ${ }^{101}$ The court then determined that the Act of 1921, chapter 8537 - the Butler Bill, which was also at issue in Bowman - was controlling. ${ }^{102}$ The Butler Bill declared: 'It is for the benefit of the State of Florida that water front property be improved and developed.'103 To promote such development, the act vested littoral owners with title to submerged lands adjacent to their littoral property. ${ }^{104}$ The act also provided such owners with, among other things, the right to 'fill up from the shore, bank or beach as far as may be desired, not obstructing the channel.' 105

Even though the City of Tampa contracted to convey sovereign submerged lands to a private party, it did not convey land, or the right to fill land, adjacent to any third party. ${ }^{106}$ This is because Davis and the City of Tampa owned all of the land adjacent to the submerged lands being conveyed, and thus, already had the right to fill such land. ${ }^{107}$ Under the Butler Bill, the City of Tampa - as a littoral owner - had the right to fill submerged lands adjacent to uplands it owned. ${ }^{108}$ Likewise, Davis had the right to fill submerged lands adjacent to his property. ${ }^{109}$ No third parties owned land adjacent to

Bowman 91 So. 2d 797-802.

Bowman 91 So. 2d 797-802.

State ex rel. Buford v City of Tampa 102 So. 336 (Fla. 1924).

Stop the Beach Renourishment, Inc. $v$ Florida Dept. of Environmental Protection 130 S. Ct. 25922611 (2010).

99 Buford 102 So. 339.

100 Buford 102 So. 339.

101 Buford 102 So. 340.

102 Buford 102 So. 340-41.

103 Act of 1921, Fla. Stat. ch. 8537 (1921); Buford 102 So. 338.

104 Buford 102 So. 341.

105 Buford 102 So. 341.

106 See Buford 102 So. 339341.

107 See Buford 102 So. 339341.

108 See Buford 102 So. 339341.

109 See Buford 102 So. 339341. 
the area being filled and the upland owners were granted the right to fill by statute; therefore, Buford cannot be cited for the proposition that the state has the right to fill sovereign submerged lands. Rather, Buford provides that a private citizen and the state - as littoral property owners - can fill submerged lands abutting their property when authorised by statute. ${ }^{110}$ Additionally, when the state owns submerged lands and the adjacent uplands, it can convey the submerged lands to a private citizen as long as it complies with any constitutional or statutory limitations. ${ }^{111}$

This conclusion is consistent with Bowman and the prevailing law at the time because the Butler Bill provided only the upland owner with the right to fill and the right only applied to submerged lands adjacent to their littoral property. ${ }^{112}$ This is also consistent with Florida law today because the Butler Bill was repealed in 1971 and upland owners no longer have a vested right to fill the seabed adjacent to their property. ${ }^{113}$ Without the Butler Bill, the City of Tampa and DP Davis - as littoral owners - would not have had the right to fill, and thus, would not have been protected by the rule set forth in State ex rel. Buford $v$ City of Tampa.

\subsubsection{Thiesen v Gulf, Florida \& Alabama Railroad Co.}

The Supreme Court cites to Thiesen $v$ Gulf, Florida \& Alabama Railroad Co. ${ }^{114}$ for the proposition that the right to accretions is subordinate to the state's right to fill. ${ }^{115}$ This conclusion is especially troubling considering the Thiesen court went out of its way-after stating the right to fill was not at issue-to indicate that the State of Florida does not have the right to fill submerged land adjacent to uplands it does not own. ${ }^{116} \mathrm{~A}$ careful analysis of Thiesen provides a general rule that the state must pay just compensation for taking an upland owner's littoral rights when the state fills the seabed adjacent to upland property it does not own. ${ }^{117}$

Thiesen involved a littoral property owner's claim that a railroad's state-authorised filling of submerged lands adjacent to his

110 See Buford 102 So. 339341.

111 See Buford 102 So. 339341.

112 See Hunt (n 91 above) 393 398-99.

113 See Fla. Stat. ch. 71-355, § 77 (1971); Fla. Stat. ch. 57-362, § 9 (1957); see also Fla. Admin. Code r. 18-21.004, 21.013 (2009); Office of Submerged Lands and Environmental Resources 'Do i need a permit?' http://www.dep.state.fl.us/ water/wetlands/ (providing permit applications for, among other things, 'construction activity that would affect wetlands, alter surface water flows, or contribute to water pollution' and 'any construction on or use of submerged lands owned by the State') (accessed 25 January 2011).

114 Thiesen v Gulf, Florida \& Alabama Railroad Co., 78 So. 491 (Fla. 1918).

115 See Stop the Beach Renourishment, Inc. v Fla. Dep't of Envtl. Prot., $130 \mathrm{~S} . \mathrm{Ct}$. 25922611 (2010).

116 Thiesen 78 So. 507

117 Thiesen 78 So. 507. 
littoral property and the construction of a railroad upon the filled land interfered with his rights to access and to wharf out to a shipping channel. ${ }^{118}$ The Thiesen court determined that the plaintiff did not have the right to construct wharves, piers, and docks, or the right to fill under the Act of 1856 because his property did not extend to the low water mark. ${ }^{119}$

Even though the littoral owner did not have a right to fill, the court determined the state did not have the ability to convey a right to fill to a third party. ${ }^{120}$ Chapter 4802, Laws of Florida 1899 purported to grant land to the City of Pensacola, and the city granted a portion of such land to the railroad. ${ }^{121}$ The court found that ' $[\mathrm{t}] \mathrm{his}$ act undertakes to deprive without compensation' the common law rights of littoral owners, ${ }^{122}$ rights which constitute property that cannot be deprived without just compensation"123 and 'cannot be arbitrarily or capriciously destroyed or impaired.'124 The court acknowledged that the state's right to fill was not at issue; however, the court implied that the state did not have the right to fill the seabed adjacent to private littoral property unless it paid just compensation for injury to the littoral landowner. ${ }^{125}$

The Thiesen court determined that the state-authorised filling of submerged land and a railroad's construction of tracks thereon

Thiesen 78 So. $500-01$

Thiesen 78 So. 501 503. Upon adoption in 1921, the Butler Bill - which was at issue in both Buford and Bowman - was made retroactive, so as to take effect from December 27, 1856, and was intended to enlarge the act of that year entitled: 'An Act to Benefit Commerce.' State ex rel. Buford v City of Tampa 102 So. 336338 (Fla. 1924).

The elements of the Butler Bill discussed above; see text accompanying notes 101-04 above; were all included in the 1856 Act to Benefit Commerce, which was at issue in Theisen. Thiesen 78 So. 491 . The 1856 act proclaimed that 'it is for the benefit of commerce that wharves be built and wharehouses erected.' Thiesen 78 So. 492. The act vested littoral owners with title to submerged lands adjacent to their littoral property, and included, among other things, the right to 'fill up from the shore, bank or beach as far as may be desired, not obstructing the channel.' Thiesen 78 So. 492. The 1856 Act required littoral owners to own land extending to the low-water mark; Thiesen 78 So. 492; and the Butler Bill only required littoral owners to own land extending to the high-water mark. Buford 102 So. 338. The land-owner in Thiesen held littoral property under the common law rule because his land extended to the high water mark; however, the owner was not entitled to rights under the Act of 1856 because his land did not extend to the low water mark. See Thiesen 78 So. 493. Under the Butler Bill, the littoral landowner in Thiesen would have also had the right to fill. See Buford 102 So. 338; see also Hayes $v$ Bowman 91 So. 2d 795800 (Fla. 1957).

121 Thiesen 78 So. $506-07$.

122 Thiesen 78 So. $505-06$.

122 Thiesen 78 So. 506.

123 Thiesen 78 So. 506. (citing Broward v Mabry 50 So. 826 (Fla. 1909)).

124 Thiesen 78 So. 507 (citing Yates v City of Milwaukee 77 US (10 Wall.) 497 (1870)).

125 Thiesen 78 So. 507 (We do not appreciate the force of the argument that the state as owner of the submerged land between high and low water mark should not, in the event it desires to improve the water front for navigation, be required to pay to the owner of the upland a just compensation for injury to his property incident to such public enterprise.). 
deprived the upland owner of his littoral rights, and the railroad would be required to pay just compensation. $\$ 26$ The court reasoned that such rights often constitute a property's 'chief value and desirability.' 127 The United States Supreme Court in Stop the Beach Renourishment, erroneously suggests the Thiesen court limited compensation to the right of access. ${ }^{128}$ The court in Thiesen did not specify that only the right to access required compensation. ${ }^{129}$ By stating that the owner was deprived of his 'rights as a riparian owner,' the court implied that all riparian rights were deprived and required compensation. ${ }^{130}$ In defining riparian rights, the court included, among other things, the right to accretions, an unobstructed view over the waters, and right of navigation, bathing, and fishing. ${ }^{131}$ If Thiesen stands for the proposition - as the Supreme Court suggests that the state, as owner of the submerged land between the high and low water marks, can fill the seabed, then it stands for the proposition that doing so requires the state to pay just compensation. ${ }^{132}$ As the court reasoned, filling the seabed 'destroys a large part of the value of plaintiff's property, perhaps by wholly depriving him of his rights as a riparian owner.

Thiesen is consistent with Florida law today because the State of Florida does not have a general right to fill. ${ }^{134}$ Florida law prohibits 'any state agency or county, city, or other political subdivision' from filling the seabed 'for a municipal, county, state, or other public purpose unless such agency is the riparian upland owner or holds the consent in writing of the riparian upland owner."135 Additionally, more recent lower court decisions such as Kendry $v$ State Road Department ${ }^{136}$ have held that the state does not have the right to fill sovereign submerged lands adjacent to littoral property it does not own. ${ }^{137}$

A close analysis of Buford, Bowman, Thiesen, and the repeal of the Butler Bill, all indicate that the United States Supreme Court

126 Thiesen 78 So. 507 .

127 Thiesen 78 So. 507

128 Stop the Beach Renourishment, Inc. v Fla. Dep't of Envtl. Prot., 130 S. Ct. 2592 2611 (2010).

129 See Thiesen 78 So. 491501503.

130 See Thiesen 78 So. 491501503.

131 Thiesen 78 So. 507

132 Thiesen 78 So. 507.

133 Thiesen 78 So. 507.

134 See Fla. Stat. \$ 253.12(5)(b) (2010).

135 Fla. Stat. \$ 253.12(5)(b) (2010). Florida Statutes section 253.12(5)(b) does not apply to situations where the Board establishes an erosion control line and authorises a beach restoration project; even so, such an extensive limitation on the state's ability to fill sovereign submerged land supports the statement that the state does not have a general right to fill. Fla. Stat. $\S 253.12(5)(\mathrm{b})(2010)$. Kendry v State Road Department 213 So. 2d 23 (Fla. Dist. Ct. App. 1968).

137 Kendry 213 So. 2d 27-28 (stating the state effectuates a taking of an upland owner's riparian rights by filling submerged land adjacent to riparian property of a private citizen and claiming title to the fill). 
erroneously determined that the State of Florida has the right to fill. The State of Florida does not have the right to fill sovereign submerged lands adjacent to littoral property it does not own. ${ }^{\Uparrow 38}$ Likewise, it does not have the ability to convey such a right to a private party that is not the upland owner. While such a finding is not conclusive proof that the Beach and Shore Preservation Act is unconstitutional, it does significantly impact the takings analysis, and thus, will be taken into account in subsequent sections of this note.

\subsection{Littoral owners have a vested right to accretions}

The court below in Walton County $v$ Stop the Beach Renourishment, Inc. ${ }^{139}$ effectuated a major change in Florida property law by categorising the right to accretions as a contingent right. ${ }^{140}$ Prior to that decision, both the United States Supreme Court and Florida Supreme Court continuously categorised the right as a vested right. ${ }^{141}$ Subsequently in Stop the Beach Renourishment, the Supreme Court found it unnecessary to categorise the right as vested or contingent because the takings clause applies in either case. ${ }^{142}$ It is necessary, however, to categorise the right to determine just compensation and to provide certainty to property owners. Maintaining consistency and predictability in littoral rights is vital in a state like Florida, especially since a vested right is more valuable than a contingent future right that may or may not come to fruition.

Littoral property owners in Florida have a vested common law ${ }^{143}$ and statutory right to accretions. ${ }^{144}$ The right is deeply rooted in American, English, and Florida law, and has gone without significant change since Blackstone set forth the rule in $1766 .^{145}$

138 Littoral property owners also do not have a right to fill; a private property owner must first obtain an authorisation to use submerged lands and an environmental resource permit prior to 'any construction activity that would effect wetlands, alter surface water flows, or contribute to water pollution.' See Office of Submerged Lands and Environmental Resources (n 113 above). Walton County $v$ Stop the Beach Renourishment, Inc., 998 So. 2d 11021118 (Fla. 2008).

140 Walton Cnty., 998 So. 2d 1118.

141 See Hughes $v$ Washington 389 US $290293-94$ (1967); Bd. of Trs. of the Internal Improvement Tr. Fund v Sand Key Assocs., Ltd., 512 So. 2d 934936 (Fla. 1987).

142 Stop the Beach Renourishment, Inc. v Fla. Dep't of Envtl. Prot., $130 \mathrm{~S}$. Ct. 2592 2601 (2010).

143 See part 3.2.1 below.

144 See part 3.2.2 below.

145 See part 2.1 above. 


\subsubsection{Common law right to accretions}

In 1976, the Florida Supreme Court determined that a littoral owner's right to accreted land is a 'vested' right that cannot be taken without just compensation and due process of law. ${ }^{146}$ In that case, the State of Florida tried to replace the mean high-water line - the fluctuating boundary between sovereign submerged lands and littoral lands with a fixed boundary. ${ }^{\text {447 }}$ The court held that the state's establishment of a fixed boundary effectuated an unconstitutional taking of private property, including the right to accretions. ${ }^{148}$ In invalidating the statute at issue, the court noted that

[b]oth Federal and Florida courts have held that an owner of land bounded by the ordinary high water mark of navigable water is vested with certain riparian rights, including the right to ... accretion[s]. ${ }^{149}$

Under these background principles of Florida property law, littoral owners have a vested common law right to accretions.

\subsubsection{Statutory right to accretions}

The United States Supreme Court analysed whether the beach restoration project constituted a taking by eliminating 'the right to accretions[] and the right to have littoral property touch the water. ${ }^{151}$ In characterising the right at issue as 'the right to have littoral property touch the water, ${ }^{152}$ the Court overlooked the right to contact the mean high-water line and the right to contact the ordinary high watermark. These rights provide a statutory right to accretions $^{153}$ and do not always guarantee contact with the water. ${ }^{154}$ Co. v Arizona 414 US 313 329-31 (1973); St. Clair Cnty. v Lovingston 90 US (23 Wall.) 46 (1874); Thiesen v Gulf, Fla. \& Ala. Ry. Co., 78 So. 491 (Fla. 1918); Padgett v Cent. \& S. Fla. Flood Control Dist., 178 So. 2d 900 (Fla. Dist. Ct. App. 1965)).

147 State $v$ Fla. Nat'l Props., Inc., 338 So. 2d 17-19.

148 State v Fla. Nat'l Props., Inc., 338 So. $2 d$ 17-18.

149 State v Fla. Nat'l Props., Inc., 338 So. 2d 17 (citing Bonelli 414 US 329-31;

Lovingston 90 US (23 Wall.) 46; Thiesen 78 So. 491; Padgett 178 So. $2 d$ 900).

150 See Bd. of Trs. of the Internal Improvement Tr. Fund v Sand Key Assocs., Ltd., 512 So. 2d 934936 (Fla. 1987); Ford v Turner 142 So. 2d 335340 (Fla. Dist. Ct. App. 1962); Mex. Beach Corp. v St. Joe Paper Co., 97 So. 2d 708710 (Fla. Dist. Ct. App. 1957).

151 See Stop the Beach Renourishment, Inc. v Fla. Dep't of Envtl. Prot., $130 \mathrm{~S}$. Ct. 2592 2610-11 \& $n 11$ (2010).

152 Stop the Beach Renourishment 130 S. Ct. 2610.

153 See text accompanying $n$ 154-61 below.

154 


\section{The right to contact the mean high-water line}

Littoral property owners in Florida have a statutory right to accretions and to contact the mean high-water line. The Florida Constitution provides that '[ $\mathrm{t}]$ he title to lands under navigable waters, within the boundaries of the state, which have not been alienated, including beaches below mean high-water lines, ${ }^{155}$ is held by the state, by virtue of its sovereignty, in trust for all the people. ${ }^{156}$ In other words, the 'mean high-water line' is the boundary between private and sovereign lands on navigable waters, and unless it has been previously alienated, the government owns the land below the mean high-water line. 157

The mean high-water line, as the boundary between private and sovereign lands, is subject to change over time because it is based on a 19 year average height of high waters. ${ }^{158}$ The upland owner gains land as the boundary moves seaward and loses land as the line moves landward. Conversely, the government loses land as the mean highwater line moves seaward and gains land as the line moves landward. This change in ownership as the mean high-water line moves is equivalent to a statutory right to accretions. ${ }^{159}$ Whether the boundary moves because of the gradual and imperceptible addition of soil to the shore of waterfront property or by the addition of land from the gradual and imperceptible withdrawal of a body of water, the Florida Constitution provides upland owners with title to accreted land. ${ }^{160}$ Title remains with the upland owner because the upland owner continues to own land up to and including the mean high-water line, even after a gradual change in the mean high water. ${ }^{161}$ As with the common law doctrine of accretions, where the loss (or addition) of land is sudden and perceptible, the doctrine of avulsion applies and

155 The 'mean high-water line' is 'the intersection of the tidal plane of mean high water with the shore.' Fla. Stat. § 177.27(15) (2010). 'Mean high water' is 'the average height of the high waters over a 19-year period.' Fla. Stat. $\$ 177.27(14)$ (2010). 'For shorter periods of observation, 'mean high water' means the average height of the high waters after corrections are applied to eliminate known variations and to reduce the result to the equivalent of a mean 19-year value.' Fla. Stat. \& 177.27(14) (2010). The 19-year value represents the 'nineteen-year tidal cycle,' which is the 'period of time generally reckoned as constituting a full tidal cycle.' Fla. Stat. § 177.27(21) (2010). The littoral owner owns up to and including the mean high-water line. Sand Key 512 So. 2d 936; State v Fla. Nat'l Props., Inc., 338 So. $2 d 13$ 18-19 (Fla. 1976); Thiesen v Gulf, Fla. \& Ala. Ry. Co., 78 So. 491493 (Fla. 1918).

156 See Fla. Const. art. X, § 11.

157 See Fla. Const. art. X, § 11; Sand Key 512 So. 2d 936; Fla. Nat'l Props., 338 So. 2d 18-19; Thiesen 78 So. 493.

158 See n 155 above.

159 See n 12 above.

160 See Fla. Const. art. X, § 11.

161 See Fla. Const. art. X, § 11. 
the boundary between sovereign submerged lands and private uplands will normally remain unchanged. ${ }^{162}$

\section{Right to contact the ordinary high watermark}

Since December 31, 1985, littoral property owners in Florida have also had a statutory right to contact the 'ordinary high watermark.'163 The right to contact the ordinary high watermark is equivalent to the right to contact the mean high-water line, ${ }^{164}$ which provides a statutory right equivalent to the common law doctrine of accretions. ${ }^{165}$

Prior to 31 December 1985, Florida Statutes section 197.228 provided in part:

Riparian rights are those incident to land bordering upon navigable waters. They are rights of ingress, egress, boating, bathing and fishing and such others as may be or have been defined by law. Such rights are not of a proprietary nature. They are rights inuring to the owner of the riparian land but are not owned by him. They are appurtenant to and are inseparable from the riparian land. The land to which the owner holds title must extend to the ordinary high watermark of the navigable water in order that riparian rights may attach. Conveyance of title to or lease of the riparian land entitles the grantee to the riparian rights running therewith whether or not mentioned in the deed or lease of the upland. ${ }^{166}$

In McDowell $v$ Trustees of Internal Improvement Fund, ${ }^{167}$ the Florida Supreme Court determined that this 'subsection [of the Florida code] was appropriately included in the chapter on taxation, and it was apparently intended by the legislature to provide a guide for the benefit of tax assessors. ${ }^{168}$ Similarly, in 1985 the Florida Supreme Court in Belvedere Development Corporation $v$ Department of Transportation, Division of Administration, ${ }^{169}$ held the same section inapplicable in a property dispute because it was tax law. ${ }^{170}$

The decision in Belvedere came down on 11 July 1985, and rehearing was denied on 4 November 1985. ${ }^{171}$ Effective 31 December 1985, the Florida Legislature renumbered section 197.228 as 253.141 and moved it from the chapter on taxation to the chapter on public

162 See part 2.1 above.

163 See text accompanying n 190-93 below.

164 See text accompanying n 189-95 below.

165 See text accompanying n 154-61 above.

166 Fla. Stat. \$ 197.228 (1983); Belvedere Dev Corp. v Dep't of Transp., Div of Admin., 476 So. 2d 649652 (Fla. 1985).

McDowell $v$ Trustees of Internal Improvement Fund 90 So. 2d 715 (Fla. 1956).

168 McDowell 90 So. 2d 717 (citing Webb v Giddens 82 So. $2 d 743745$ (Fla. 1955)).

169 Belvedere 476 So. 2d 649.

170 Belvedere 476 So. 2d 652-53 (citing Maloney, Plager \& Balwin Water law and administration (1968) § 34.3).

171 Belvedere 476 So. 2d 649. 
lands and property. ${ }^{172}$ No other changes were made to the law on that date, ${ }^{173}$ and the statute remains in effect without any substantive changes. ${ }^{174}$

The sole reason the Belvedere court found section 197.228 inapplicable in a property dispute was its inclusion in the chapter on taxation. ${ }^{175}$ Belvedere was effectively overruled in less than six months when the Florida legislature renumbered section 197.228 and moved it to the public lands and property chapter. ${ }^{176}$

While the definition of 'riparian rights' was renumbered in the Florida code and included in the chapter on public lands and property, there is no legislative history explaining the change and the change has not been well developed in Florida case law. ${ }^{177}$ Cases after 1985 have cited to Florida Statutes section 253.141 for the definition of riparian (or littoral) rights in the context of property disputes; however, application of the definition has been inconsistent. Some courts have applied the definition to private property owners ${ }^{178}$ and others have limited its applicability to public lands. ${ }^{179}$ In either case, the Florida legislature codified some of the rights of riparian land owners $^{180}$ that were previously predominately determined by common law. 181

Fla. Stat. \$ 253.141 (2010). Florida Statutes section 253.141 has remained unchanged since 31 December 1985, with the exception that the sentence ' $[t]$ hey are rights inuring to the owner of the riparian land but are not owned by him' now reads 'him or her.' Compare Fla. Stat. § 253.141 (2010), with Fla. Stat. § 253.141 (1985).

175 See Belvedere 476 So. $2 \mathrm{~d} 652-53$

Fla. Admin. Code r. 18-21.004(3) (2010) (indicating that Florida Statutes section 253.141 defines the 'traditional, common law riparian rights ... of upland property owners adjacent to sovereignty submerged lands').

177 TB Proctor 'Erosion of riparian rights along Florida's coast' (2004) 20 Journal of Land Use \& Environmental Law 117 132-36.

178 See Teat $v$ City of Apalachicola 738 So. 2d 413 413-14 (Fla. Dist. Ct. App. 1999) (" $[A] n$ individual must own property down to the ordinary high water mark in order to possess riparian rights.'); see also Tewksbury $v$ City of Deerfield Beach 763 So. 2d 1071 1071-72 (Fla. Dist. Ct. App. 1999) (applying section 253.141 in a dispute between owners of privately-owned submerged land and owners of the privately-owned adjacent uplands); Haynes v Carbonell 532 So. 2d 746748 (Fla. Dist. Ct. App. 1988).

179 City of Tallahassee v J.R. 771 So. 2d 587588 (Fla. Dist. Ct. App. 2000) ('The City's reliance on the definition of "riparian rights"' found in section 253.141, Florida Statutes (1999), is also misplaced, for that chapter relates to State-owned lands ...').

180 Fla. Admin. Code r. 18-21.004(3) (2010). Even the court in Webb v Giddens noted - prior to the Florida Legislature renumbering Florida Statutes section 197.228 that ' $[\mathrm{w}]$ hile this statute is included in the chapter on Taxation and Finance, ... it may be accepted as a partial codification of the common law on the subject.' Webb v Giddens 82 So. 2d 743745 (Fla. 1955).

181 See Belvedere Dev Corp. $v$ Dep't of Transp., Div of Admin., 476 So. $2 \mathrm{~d} 649$ (Fla. 1985); Hayes $v$ Bowman 91 So. 2d 795 (Fla. 1957); State ex rel. Buford $v$ City of Tampa 102 So. 336 (Fla. 1924); Thiesen v Gulf, Fla. \& Ala. Ry. Co., 78 So. 491 (Fla. 1918). 
If the definition of 'riparian rights' in Florida Statutes section 253.141 only applies to public lands, then presumably the common law definition of riparian rights would still apply to private-property owners. While two separate definitions would not cause a problem in a dispute between two private land-owners, it could cause significant problems in a dispute between the government and a private property-owner. The government and private property owner could have overlapping rights; the private land-owner could be entitled to riparian rights under common law and the government could be entitled to the same rights by statute. To avoid conflicting rights, promote continuity, and increase the marketability of land bordering navigable waters, courts should apply the definition of 'riparian rights,' as found in Florida Statutes section 253.141, to all property. ${ }^{182}$

Assuming arguendo, that the definition of 'riparian rights' in section 253.141 only applies to public lands, it still provides an adequate definition to determine if a taking occurs where the government-as a land owner-is a party to a dispute in which littoral rights are at issue. If the state obtains littoral rights under the statute, then either (1) the private owner has been deprived of such littoral rights, ${ }^{183}$ or (2) the government has littoral rights in common with the private land-owner. ${ }^{184}$ In either case, a taking has occurred because the littoral owner has been deprived of littoral rights ${ }^{185}$ or of exclusive ownership of littoral rights. ${ }^{186}$

In defining riparian rights, Florida Statutes section 253.141 provides that the owner of land 'extend[ing] to the ordinary high watermark of the navigable water' has riparian 'rights of ingress, egress, boating, bathing and fishing and such others as may be or have been defined by law. ${ }^{187}$ It is clear from the statute that the owner of

It is also important to note that in defining 'riparian rights,' section 253.141 uses the pronouns 'him' and 'her' when referring to the land-owner. Fla. Stat. \$ 253.141 (2010). If the definition of riparian rights was only intended to apply to public land, then the pronouns 'him' and 'her' should have been avoided. The pronouns 'him' and 'her' indicate the definition applies to more than the government, which would correctly be referred to as 'it."

183 The government is entitled to littoral rights under Florida Statutes section 253.141 if it acquires the mean high-water line. Fla. Stat. § 253.141 (2010). When the government acquires the mean high-water line, the upland owner ceases to be entitled to littoral rights because the upland property is no longer considered littoral. See $\mathrm{n} 155$ above.

184 See text accompanying n 179-82 above.

185 See eg, Webb's Fabulous Pharmacies, Inc. v Beckwith 449 US 155 163-65 (1980).

186 For example, under Florida Statutes section 253.141, the owner of the mean highwater line is entitled to the rights of ingress and egress. Fla. Stat. § 253.141 (2010). If the government has the rights of ingress and egress, the upland littoral owner has been deprived of the right to exclude others. See eg, Kaiser Aetna $v$ United States 444 US 164176 (1979) (compelling public access would deprive 'the owner ... [of] one of the most essential sticks in the bundle of rights that are commonly characterised as property-the right to exclude others')

Fla. Stat. § 253.141 (2010). 
land extending to the ordinary high watermark is entitled to riparian rights; however, 'ordinary high watermark' is not defined in the section. ${ }^{188}$ Ordinary high watermark is also not defined in Black's Law Dictionary ${ }^{189}$ or in the Florida Statutes section on land boundaries. ${ }^{190}$

The Florida Supreme Court has used the phrase 'ordinary high water mark' to describe the boundary between private and sovereign lands on navigable waters. ${ }^{191}$ The Florida Constitution uses the phrase 'mean high-water line' to describe the same boundary. ${ }^{192}$ Since the 'ordinary high watermark' and the 'mean high-water line' are both defined as the boundary between private and sovereign lands and both have been used in the same context in property disputes, it follows that they should have the same meaning. Therefore, the 'ordinary high watermark' is defined as 'the intersection of the tidal plane of mean high water with the shore;"193 and it represents the boundary between private and sovereign property on navigable waters. ${ }^{194}$

Much like littoral owners have a right to contact the mean high water line, ${ }^{195}$ littoral owners have a right to contact the ordinary high watermark. ${ }^{196}$ As the boundary between sovereign and private property gradually moves with the changing of the tide, the upland owner continues to own land up to and including the ordinary high watermark. ${ }^{197}$ The government, as owner of the property below the ordinary high watermark, receives a corresponding reciprocal benefit or burden depending on whether the line moves landward or seaward respectively. Although not called a right to accretions, this change in ownership is equivalent to the common law right to accretions and it is subject to the doctrine of avulsion. ${ }^{198}$

Although inherent in the Florida Constitution and in Florida Statutes, the statutory right to accretions has not been developed by

See Garner (n 1 above). Blacks Law Dictionary does define 'high-water mark' as '[t] he shoreline of a sea reached by the water at high tide ... usually computed as a mean or average high tide and not as the extreme height of the water.' Garner (n 1 above) 1730. This is consistent with the meaning of mean high-water line. See Fla. Stat. § 177.27(14) (2010).

190 See Fla. Stat. § 177.27 (2010) (providing definitions for the chapter on land boundaries).

191 Bd. of Trs. of the Internal Improvement Tr. Fund v Sand Key Assocs., Ltd., 512 So. 2d 934936 (Fla. 1987) ('[A] riparian or littoral owner owns to the line of the ordinary high water mark on navigable waters.'); accord State v Fla. Nat'( Props., Inc., 338 So. 2d 1317 (Fla. 1976); Hayes v Bowman 91 So. 2d 795799 (Fla. 1957); Brickell v Trammell 82 So. $221226-27$ (Fla. 1919); Thiesen v Gulf, Fla. \& Ala. Ry. Co., 78 So. 491 493-94 (Fla. 1918).

192 See Fla. Const. art. X, § 11.

193 See Fla. Stat. § $177.27(14)$ (2010).

194 Sand Key 512 So. 2d 936; Fla. Nat'l Props., 338 So. 2d 18-19; Thiesen 78 So. 493.

195 See text accompanying n 154-61 above.

196 See Fla. Stat. § 253.141 (2010).

197 See Fla. Stat. § 253.141 (2010)

198 See n 12 above. 
the courts. Prior to the Florida Supreme Court's decision in Walton County, the common law right to accretions was continually categorised as a vested right. ${ }^{199}$ The Walton County court reclassified the right as a contingent future right and cast doubt on the rights associated with owning littoral property. ${ }^{200}$ With the Beach and Shore Preservation Act authorising elimination of the right to accretions ${ }^{201}$ and nearly half of all Florida beaches being considered critically eroded, a significant portion of property owners are now at risk of losing the right to accretions. ${ }^{202}$ Recognition of the statutory right to accretions will increase the marketability of littoral property and restore consistency to an area of law that went unchanged for nearly a hundred years prior to Walton County. ${ }^{203}$ Considering that the right to accretions is based in both common law and the Florida Constitution, it should continue to be categorised as a vested right and courts should take notice of the statutory right to accretions.

\subsection{The avulsive event at issue}

As the Supreme Court correctly contends, an avulsive event will eliminate a littoral owner's right to accretions; ${ }^{204}$ however, the right is only permanently eliminated if the affected owner fails to take action and reclaim the land lost to the avulsive event. 205 The United States Supreme Court and the Florida Supreme Court both cite avulsive events as justification for eliminating the right to accretions; however, the courts do not cite to the same event. ${ }^{206}$

In Walton County, the Florida Supreme Court determined the beach restoration project was merely the state reclaiming 'stormdamaged shoreline' after a series of hurricanes. ${ }^{207}$ The court upheld the Beach and Shore Preservation Act because it authorised an act already allowed at common law, the reclamation of lands affected by an avulsive event. ${ }^{208}$

The United States Supreme Court cited the lower court's reclamation analysis but stated that ${ }^{209}$

See eg, Sand Key 512 So. $2 d 936$.

200 See Walton Cnty. $v$ Stop the Beach Renourishment, Inc., 998 So. 2d 1102 1118-20 (Fla. 2008).

201 Fla. Stat. 161.191 (2010)

202 See Bureau of Beaches and Coastal Systems (n 20 above).

203 See part 2.1 above.

204 Stop the Beach Renourishment, Inc. v Fla. Dep't of Envtl. Prot., 130 S. Ct. 2592 2612 (2010) (citing Walton Cnty., 998 So. 2d 1117 1120-21).

205 See State $v$ Fla. Nat'l Props., 338 So. 2d 13 18-19 (Fla. 1976).

206 Compare Stop the Beach Renourishment $130 \mathrm{~S}$. Ct. 2611-12 with Walton Cnty. 998 So. 2d 1117-18.

207 Walton Cnty., 998 So. 2d 1117-18.

208 Walton Cnty., 998 So. 2 d 1117-18.

209 Stop the Beach Renourishment 130 S. Ct. 2611-12. 
Florida law as it stood before the decision below allowed the State to fill in its own seabed, and the resulting sudden exposure of previously

submerged land was treated like an avulsion for purposes of ownership.

Even though the Supreme Court cited the Florida court's analysis, it relied on a different avulsive event as justification for eliminating the right to accretions.

The lower court's analysis hinges on the state's right to reclaim land lost to an avulsive event prior to the beach restoration project. ${ }^{210}$ In contrast, the Supreme Court's analysis hinges on the actual restoration project being the avulsive event that justifies eliminating the right to accretions. ${ }^{211}$ These two approaches result in significantly different analyses, neither of which provides an adequate justification for eliminating the littoral owners' right to accretions without paying just compensation. ${ }^{212}$

\subsubsection{The Florida Supreme Court erroneously held that reclaiming land lost to an avulsive event results in elimination of the littoral owners' right to accretions}

The Florida Supreme Court determined the avulsive event at issue was the reclamation of 'storm-damaged shoreline by adding sand to submerged sovereignty lands.' 213 The court relied on State v Florida National Properties, Inc. ${ }^{214}$ and held that the reclamation of lands through a beach restoration project did not constitute a taking of the upland owners' right to accretions. ${ }^{215}$ In Florida National Properties, littoral property owners utilised self-help dynamiting measures to lower water levels on Lake Istokpoga after a hurricane caused the water level to rise. ${ }^{216}$ The self-help measures did not lower the water level below the normal high-water mark, but rather, 'merely returned the water to its normal level and did not expose any lake bottom.'217 By lowering the water, the littoral property owners successfully reclaimed, within a reasonable time, the right to accretions and their land affected by the avulsive event. 218

The Florida Supreme Court failed to mention that the littoral property owners in Florida National Properties did not permanently lose the right to accretions. ${ }^{219}$ The property owners reclaimed the right to accretions because after the avulsive event and subsequent

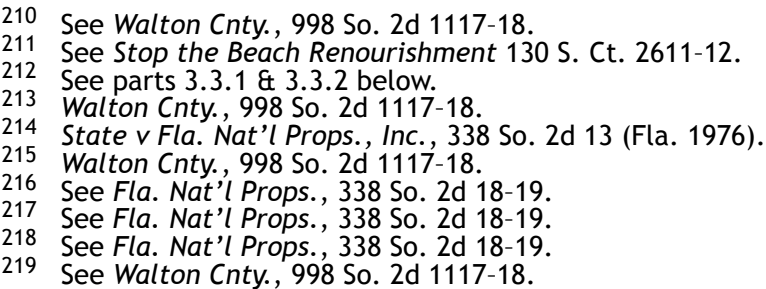


reclamation, the water returned to the pre-avulsive mean high-water line and there was no net effect on the property. ${ }^{220}$ It follows then that when, as the Florida Supreme Court contends is the case here, the state fills sovereign submerged lands pursuant to a beach restoration project in an attempt to 'reclaim' lands lost to an avulsive event, the reclamation eliminates the effect of the avulsive event and the right to accretions is preserved. ${ }^{221}$ Therefore, the reclamation of lands affected by the avulsive event that led to the beach restoration project cannot justify eliminating the littoral owners' right to accretions.

\subsubsection{The United States Supreme Court erroneously held that the state filling of sovereign submerged lands results in elimination of the littoral owners' right to accretions}

The United States Supreme Court relied on the beach restoration project as the avulsive event that justifies elimination of the littoral owners' right to accretions. ${ }^{222}$ While filling the seabed is a sudden and perceptible addition to land that is considered an avulsive event, the Court's analysis is flawed. The state does not have the right to fill sovereign submerged lands adjacent to littoral property it does not own. ${ }^{223}$ Much like a littoral owner cannot gain land through selfinduced artificial accretions, the government cannot eliminate a littoral owner's right to accretions by filling submerged lands it does not have the right to fill. ${ }^{224}$ As such, the doctrine of avulsion cannot justify taking the littoral owners' right to accretions without paying just compensation. ${ }^{225}$

Assuming arguendo, that the state does have the right to fill, the Court still erroneously held that such a right justifies taking the littoral owners' right to accretions. The state authorised filling of the seabed (the beach restoration project) had not occurred at the time the littoral owners' right to accretions was eliminated; therefore,

See Fla. Nat'l Props., 338 So. 2d 18-19.

See Fla. Nat'l Props., 338 So. 2d 18-19.

Stop the Beach Renourishment, Inc. v Fla. Dep't of Envtl. Prot., 130 S. Ct. 2592 2611-12 (2010) (stating that the right to accretions was not implicated by the Beach and Shore Preservation Act because the State's right to fill the seabed was superior to the littoral landowner's right to accretions, and because the doctrine of avulsion applied).

See part 3.1 above.

Compare Thiesen v Gulf, Fla. \& Ala. Ry. Co., 78 So. 491 506-07 (Fla. 1918); with $B d$. of Trs. of the Internal Improvement Tr. Fund v Medeira Beach Nominee, Inc. 272 So. 2d 209212 (Fla. Dist. Ct. App. 1973) ('[L]and below the ordinary high water mark is sovereignty land of the state, [and] to permit the riparian owner to cause accretion himself would be tantamount to allowing him to take state land.').

See Thiesen 78 So. 491. 
there was no avulsive event to justify the taking. ${ }^{226}$ Since the Court's proposed avulsive event of filling the seabed had not occurred at the time the right was eliminated, the Court should have disregarded the proposed filling and analysed whether there was a taking without just compensation on the date the right was eliminated.

\subsection{Establishing a fixed erosion control line constitutes a taking because it eliminates the littoral owners' vested right to accretions}

The Fifth Amendment Takings Clause - 'nor shall private property be taken for public use, without just compensation' 227 - applies to the taking of private property, including littoral rights. ${ }^{228}$ Regulatory takings jurisprudence 'aims to identify regulatory actions that are functionally equivalent to the classic taking in which government directly appropriates private property or ousts the owner from his domain.'229 A taking occurs when a regulation requires a property owner to submit to a permanent physical occupation, ${ }^{230}$ where the government deprives an owner of all economically beneficial use of his property, ${ }^{231}$ or where the government recharacterises private property as public property. ${ }^{232}$ While states have the ability to change property law, a state cannot transfer established, long recognised, and essential property rights from a citizen to the state without paying just compensation. 233

In Florida, littoral owners have a vested right to accretions ${ }^{234}$ that is an essential attribute to ownership of waterfront lands. ${ }^{235}$ The right has been long recognised and has gone without significant change

See Fla. Stat. § 161.191 (2010). The Beach and Shore Preservation Act eliminates the littoral owner's right to accretions upon recording the ECL in the county real property records-an event that occurs prior to the state filling the seabed. See Fla. Stat. § 161.191 (2010).

227 US Const. amend. v The Fifth Amendment applies against the states through the Fourteenth Amendment. Penn Cent. Transp. Co. v City of New York 438 US 104 122 (1978).

228 See Yates $v$ City of Milwaukee 77 US (10 Wall.) 497504 (1870); see also Thiesen 78 So. 507 ('Riparian rights ... are property, and, being so, the right to take it for public use without just compensation does not exist.'). The Florida State Constitution provides a similar limitation on government: "No private property shall be taken except for a public purpose and with full compensation.' Fla. Const. art. X, \& 6(a).

229 Lingle v Chevron USA Inc., 544 US 528539 (2005).

230 Loretto $v$ Teleprompter Manhattan CATV Corp., 458 US 419 435-36 (1982).

231 Lucas v S.C. Coastal Council 505 US 10031019 (1992).

232 Webb's Fabulous Pharmacies, Inc. v Beckwith 449 US 155 163-65 (1980).

233 Webbs's 449 US 163-65.

234 See part 3.2 above.

235 See eg, Thiesen v Gulf, Fla. \& Ala. Ry. Co., 78 So. 491507 (Fla. 1918). 
since $1766 .{ }^{236}$ As such, the right to accretions cannot be taken without just compensation. ${ }^{237}$

In accordance with the Beach and Shore Preservation Act, the littoral owners' common law right to accretions was eliminated and transferred to the government upon recording the erosion control line in the county real property records. ${ }^{238} \mathrm{At}$ no time prior to the transfer, or any time thereafter, did an avulsive event occur that would justify taking the littoral owners' vested right to accretions without paying just compensation. ${ }^{239}$ Additionally, the reclamation of lands affected by the avulsive event that led to the beach restoration project cannot justify eliminating the owners' right to accretions. ${ }^{240}$

As shown in Florida National Properties, and as is the case here, when there is no net effect after an avulsive event and a subsequent reclamation within a reasonable time, a state set fixed boundary for littoral property constitutes an unconstitutional taking. ${ }^{241}$ Setting such a boundary without the occurrence of a justifiable avulsive event eliminates the littoral owners' vested right to accretions and requires just compensation. ${ }^{242}$ Since the right to accretions is an essential and established right of littoral property owners and since no avulsive event justified elimination of the right, the government effectuated an unconstitutional taking of the right to accretions upon setting the ECL. ${ }^{243}$ As such, the Court's opinion in Stop the Beach Renourishment, Inc. v Florida Department of Environmental Protection was flawed, and the littoral property owners in that case should have been entitled to just compensation for the right to accretions.

\section{Conclusion}

In Stop the Beach Renourishment, Inc. v Florida Department of Environmental Protection, the United States Supreme Court

Bd. of Trs. of the Internal Improvement Tr. Fund $v$ Sand Key Assocs., Ltd., 512 So. 2d 934936 (Fla. 1987) (quoting Brickell v Trammell 82 So. 221227 (Fla. 1919)); see also Broward v Mabry 50 So. 826830 (Fla. 1909).

238 Fla. Stat. § 161.191 (2010) ("TT]he common law shall no longer operate to increase or decrease the proportions of any upland property lying landward of such line, either by accretion or erosion or by any other natural or artificial process.'). The statutory right to accretions discussed in part 3.2.2 has not been developed in case law. Although not explicit in the Beach and Shore Preservation Act, the upland property owner's common law right to accretions is transferred to the government upon recording the ECL. As the mean high-water line gradually and imperceptibly recedes seaward of the ECL and dry land is added to the shore of waterfront property, the boundary between private property and sovereign lands remains unchanged and the government retains title to the lands seaward of the erosion control line. See Fla. Stat. § 161.191 (2010).

241 See part 3.3.1 above.

242
See State v Fla. Nat'l Props., Inc., 338 So. 2d 13 18-19 (Fla. 1976).

See Fla. Nat'l Props., 338 So. 2 d 13 18-19. 
erroneously upheld Florida's Beach and Shore Preservation Act against a facial constitutional challenge. The Court used two conclusory paragraphs to set forth the background principles of Florida property law, ${ }^{244}$ and in doing so, misinterpreted Florida law at virtually every possible chance. A careful analysis of the cases relied on by the Court indicates the opposite of the Court's conclusion, that the State of Florida does not have the right to fill sovereign submerged lands adjacent to uplands it does not own. 245

Florida's Beach and Shore Preservation Act provides for elimination of the right to accretions without the occurrence of an avulsive event to justify such elimination. ${ }^{246}$ In erroneously upholding the Act and the Florida Supreme Court's decision, the United States Supreme Court contributed to the erosion of littoral rights in Florida. The right to accretions, which was previously classified as a vested right, ${ }^{247}$ is now considered a contingent future right that is far less valuable. ${ }^{248}$ With almost half of the beaches in Florida eligible for a beach restoration project, ${ }^{249}$ littoral owners in Florida are now at risk for losing the right to accretions. ${ }^{250}$ Considering its base in both common law ${ }^{251}$ and the Florida Constitution, ${ }^{252}$ courts need to recognise the right to accretions as a vested right and finally take notice of the statutory right to accretions.

243 It is also important to note that the Act contradicts the established rationale for the doctrine of accretions. Accretion is founded on the principle that "he who sustains the burden of losses and of repairs imposed by the contiguity of waters ought to receive whatever benefits they may bring by accretion.' See Bd. of Trs. of the Internal Improvement Tr. Fund v Medeira Beach Nominee, Inc., 272 So. 2d 209 212-13 (Fla. Dist. Ct. App. 1973) (citing St. Clair Cnty. v Lovingston 90 US (23 Wall.) 4667 (1874)). The Act provides for cancellation of the ECL when the 'governmental agency charged with the responsibility of maintaining the protected beach fails to maintain the same and as a result thereof the shoreline gradually recedes to a point or points landward of the erosion control line.' Fla. Stat. § 161.211 (2010). This provision contradicts Florida's rationale behind the doctrine of accretion because the government receives the benefit of receiving land by accretion but does not sustain the burden of losing land through erosion. Similarly, this provision of the Act also contradicts the rationale set forth by Blackstone. See Blackstone (n 31 above) 261-62 ("[A]nd besides, these owners being often losers by the breaking in of the sea, or at charges to keep it out, this possible gain is, therefore, a reciprocal consideration for such possible charge or loss.'). See Stop the Beach Renourishment, Inc. v Fla. Dep't of Envtl. Prot., 130 S. Ct. 2592 2611-12 (2010).

245 See part 3.1 above.

246 See parts 2.2 \& 3.3 above.

247 See part 3.2 above.

248 See Walton Cnty. $v$ Stop the Beach Renourishment, Inc., 998 So. 2d 1102 1118-20 (Fla. 2008).

249 See Fla. Stat. § 161.088 (2010); Bureau of Beaches and Coastal Systems (n 20 above).

250 See Fla. Stat. § 161.191 (2010).

251 See part 3.2.1 above.

252 See part 3.2.2 above. 
While the right to accretions is subject to the doctrine of avulsion, ${ }^{253}$ the Court incorrectly held that an avulsive event justified taking the littoral owners' right to accretions. The Court cited two different avulsive events as justification for eliminating the right to accretions; however, neither event provides such justification. ${ }^{254}$ The beach restoration project itself cannot provide justification for eliminating the right because the state does not have the right to fill, ${ }^{255}$ and at the time the right was eliminated, the beach restoration project had not taken place. ${ }^{256}$ The reclamation of lands lost to an avulsive hurricane also cannot justify eliminating the right because reclamation within a reasonable time preserves the right to accretions. ${ }^{257}$

Without the occurrence of a justifying avulsive event (or in the case of a reclamation within a reasonable time), a state set fixed boundary between private and sovereign property on navigable waters constitutes a taking of the upland owner's right to accretions. ${ }^{258}$ As such, the upland owners in Stop the Beach Renourishment, Inc. $v$ Florida Department of Environmental Protection should have been entitled to just compensation. 



\title{
ACCESS TO SOCIAL SECURITY FOR NON-CITIZENS: AN INTERNATIONAL, SOUTH AFRICAN AND EUROPEAN VIEW
}

\author{
by Taryn Lee Vos*
}

\section{Introduction}

South Africa has become a magnet to a larger group of foreign migrants than the global average. ${ }^{1}$ This is due to the fact that it is a front-runner, economically speaking, in Sub-Sahara Africa with a reputation of political stability. ${ }^{2}$ The South African Constitution ${ }^{3}$ is the supreme law of the Republic, to which all other law is subject. South Africa's constitutional framework, coupled with immigration legislation and policies, aim to promote the rights enshrined in the Bill of Rights ${ }^{4}$ for all individuals living within the borders of the Republic. ${ }^{5}$ While certain rights are expressly reserved for citizens only and are largely of a civil or political nature, the remaining rights are those that 'everyone', including foreign nationals, may enjoy. Non-citizens within the borders of the Republic receive, inter alia, the protection of South Africa's basic constitutional values; in particular the right to equality, human dignity and freedom. Socio-economic rights, subject to the limitations clause in section 36 of the Constitution, are also made available to everyone. This includes both citizens and foreign nationals. These rights can be found in section 25, 26, 27, 28 and 29 of the Constitution and relate to issues of access to land, housing, health care, food, social security and education.

The focus of this paper will be the right of access to social security for non-citizens, particularly migrants, in South Africa. Who falls within the scope of the term 'everyone' as found in section 27 of the Constitution? The international perspective on the issue of social exclusion of non-citizens from accessing social security benefits is

* Final year LLB student, University of Stellenbosch. I acknowledge with thanks the assistance and wisdom of Professor Henk Botha (University of Stellenbosch).

1 International Federation for Human Rights (FIDH) International Federation for Human Rights Report 'Surplus People? Undocumented and other vulnerable migrants in South Africa' (2008) 8.

International Federation for Human Rights (n 1 above) 8.

Constitution of the Republic of South Africa, 1996 ('the Constitution').

Ch 2 of the Constitution.

Sec 7(2) of the Constitution. 
briefly dealt with, followed by a discussion of the South African perspective on the matter. The approach of the South African Constitutional Court in respect of the protection of the rights of noncitizens will then be discussed. The European approach to the matter, including the approach of European courts, will then be examined. The concluding paragraphs entail an evaluation of the improvements that can be made to the South African social security system as inspired by the European approach.

\section{Social security: a conceptual view}

The right of access to social security as envisaged in section 27 of the Constitution is available to 'everyone' (regardless of nationality) and includes access to the appropriate social assistance should anyone be unable to support themselves or their dependants. Social security ${ }^{6}$ consists primarily of social insurance and social assistance. ${ }^{7}$ The social insurance system in South Africa is relatively well-developed ${ }^{8}$ and provides benefits to those in formal employment, for example, unemployment insurance and worker's compensation. Social assistance, on the other hand, has a more strict and exclusive scope (especially the grant system) and provides benefits according to a categorical, means-tested standard. The definition of social security is not a rigid one and varies according to the characteristics of each country. ${ }^{9}$

\section{The international perspective}

The right to social security has a certain universality since it presupposes that those who find themselves in a vulnerable situation should be protected due to their membership to society. Access to social security and protection of non-citizens is a problematic issue, largely due to the tensions between social security and redistribution and the fact that conventional social insurance systems are employment-based. Consequently social security can be a discriminating matter. ${ }^{10}$ Without international protection noncitizens, especially migrant workers, find themselves at risk of

D Kasente 'Gender and social security reform in Africa' (2000) 53 International Social Security Review 27 30. The concept of social security is ill-defined, but according to Kasente can be used to include the 'totality of organisational forms through which goods and services are provided to people in situations of need and distress when they cannot achieve security by their own individual means.'

7 The modern approach to social security is distinct from the broader concept of 'social protection' which refers to a system of welfare support.

8 A Dekker et al 'Social security: a conceptual view' (2000) 4 Law, Democracy \& Development 12.

9 Dekker et al (n 8 above) 2 - 4.

10 U Becker \& MP Olivier Access to social security for non-citizens and informal workers: An international, South Africa and German perspective (2008) xiii. 
exclusion from accessing social security in both their home and host nations. ${ }^{11}$ Article 2 of the Equality of Treatment (Accident Compensation) Convention 19 of 1925 and article 8 of the Equality of Treatment (Social Security) Convention 118 of 1962 ('Convention $\left.118^{\prime}\right)$ are examples of international instruments that have set certain standards regarding the social security plight of non-citizens. Convention 118 allows for a certain period of residence to be prescribed for the receipt of certain benefits. ${ }^{12}$ The Minimum Standards of Social Security Convention ${ }^{13}$ is authority for the equal treatment of citizens and non-citizen residents with regards to social insurance schemes. This Convention allows for the exclusion of noncitizens where benefits or part of the benefits are payable entirely from public funds (tax-funded or non-contributory social security benefits).

The large majority of social security conventions do leave room for flexibility with regards to social assistance access for non-citizens. Article 6 of the Migration for Employment Convention ${ }^{14}$ prohibits discriminatory treatment between 'immigrants lawfully within its territory' and nationals with regards to trade union rights, accommodation rights, employment rights and social security rights. The Migrant Workers Convention ${ }^{15}$ provides that states should commit themselves to advance and guarantee

equality of opportunity and treatment in respect of employment and occupation, of social security, of trade union and cultural rights of individual and collective freedoms for persons who as migrant workers or as members of their families are lawfully within its territory. ${ }^{16}$

The inclination to provide rights to non-citizens lawfully residing within the territory of a host nation is evident.

\section{The South African perspective}

Universal access to social security and an adequate standard of living can be regarded as both a fundamental human right and a policy objective in South Africa. Section 27 of the Constitution not only guarantees 'everyone' the right of access to social security but also imposes a duty on the state to take reasonable legislative and other measures, within the available resources, to achieve the progressive realisation of this right. The laws, regulations and rules that govern social security do not always offer solid answers regarding eligibility

Becker \& Olivier (n 10 above) 7.

Art 4(2) of Convention 118 excludes sickness benefit, employment injury benefit, medical care and family benefit from this requirement.

ILO 102/1952.

ILO 97/1949.

ILO 143/1975.

Becker \& Olivier (n 10 above) $23-25$. 
to social security benefits. The short-comings in the social security system often result in the exclusion of the marginalised. ${ }^{17}$

Generally speaking non-citizens are excluded from social security protection especially when it comes to social assistance. The Social Assistance Act13 of 2004 (the 'Social Assistance Act') is the most comprehensive instrument regulating social assistance. ${ }^{18}$ South African citizenship is an eligibility requirement in order to receive access to the large majority of social assistance benefits. Section 5(c) of the Social Assistance Act specifically restricts social grants to South African citizens. The Constitutional Court in Khosa and Others $v$ Minister of Social Development and Others; Mahlaule and Others $v$ Minister of Social Development and Others ${ }^{19}$ ('Khosa') has, however, extended the scope of the Social Assistance Act and held that permanent residents are entitled to access to social assistance grants. A means test must be complied with in order to receive access to the grants.

Certain groups of non-citizens do enjoy full legal protection including rights as set out in chapter 2 of the Constitution. Those who have gained refugee status ${ }^{20}$ enjoy the section 27 socio-economic rights. This would include the right of access to social security and the suitable social assistance in situations where the refugees are incapable of supporting themselves and those dependent on them. Despite this protection the Social Assistance Act does not include refugees in its scope of protection. The two Acts appear to be in conflict with one another. ${ }^{21}$ Section 2(1) of the Social Assistance Act also provides that where a bilateral agreement exists between SA and a non-citizen's country of origin that non-citizen will receive coverage. These bilateral agreements do not include international instruments.

\subsection{International influence on the South African position}

Arguably the most comprehensive and contentious international instrument is the International Convention on the Protection of Rights of All Migrant Workers and Members of their Families. ${ }^{22}$ The purpose of the Convention is to extend social protection to migrants and their families, including those that are irregular or undocumented migrants. In the absence of discrimination based on status, access to social security is one of the rights guaranteed to all migrants under

Becker \& Olivier (n 10 above) 60.

As above.

20046 SA 505 (CC).

Refugees Act 130 of $1998 \mathrm{sec} 3(\mathrm{a})$.

'Comparative review of the position of non-citizen migrants in social security'

Report for the South African Treasury (2004) 39- 40.

22

GA Res 45/158. 
this Convention. Several states, including South Africa, have not ratified or signed this Convention in the fear that it may encourage irregular migration. ${ }^{23}$ Regardless, the basic principles of equality and human rights are respected in South Africa through the adherence to international human rights law. South Africa has also committed itself to the protection of all foreign children's right of access to social protection through the ratified Convention of the Rights of Children. ${ }^{24}$

South Africa has also ratified several other international agreements that require a commitment to advancing the right of access to social security for non-citizens including the Universal Declaration of Human Rights $(1948)^{25}$ - which states that everyone, as a member of society, is entitled to social security - and the United Nations Declaration on the Human Rights of Individuals who are not Nationals of the Country in which they Live (1985). ${ }^{26}$ Although South Africa has little involvement in social security agreements its rightsbased approach has been effective, to a degree, in protecting the right of access to social security of non-citizens. ${ }^{27}$

\subsection{The position of migrants according to the Constitutional Court}

The judgement in Khosa played a key role in improving access to social assistance for migrants who are permanent residents of South Africa. The constitutionality of certain provisions of the Social Assistance Act 59 of 1992 (the Act) were challenged by Mozambican citizens (permanent residents of South Africa) who were excluded from social assistance. They would have been entitled to social assistance under the Act but for the requirement of citizenship. The applicants argued that their exclusion was contrary to the state's duties under section 27(1)(c) of the Constitution. They also claimed that their section 9 right to equality had been limited and could not be justified in terms of the section 36 general limitations clause of the Constitution. It was held that the Bill of Rights protects the rights of 'all people in our country' and that section 27 of the Constitution does provide that everyone has the right of access to social security. ${ }^{28}$ Section $27(1)$ showed no indication that the right was restricted to citizens alone.

AH Dekker'The social protection of non-citizen migrants in South Africa' (2010) 22 SA Mercantile Law Journal 388-392.

UN General Assembly Document A/RES/44/25. This Convention was ratified on 16 June 1995.

GA res 217A (III) UN Doc A/810 71.

GA res 40/144, annex, 40 UN GAOR Supp (No. 53) 252, UN Doc A/40/53.

Becker \& Olivier (n 10 above) 10

Sec 27(2) also imposes a duty on the state to take reasonable legislative and other measures, within the available resources, to achieve the progressive realisation of this right as mentioned in paragraph 4. 
The term 'everyone', as found in the provision, included both citizens and non-citizens. ${ }^{29}$

The Court found it reasonable to exclude certain non-citizens from this entitlement, for example, workers who were citizens of another country, illegal residents and visitors. Permanent residents were included as their link to the country was not feeble. It was felt that denying permanent residents social security would be an attack on their constitutional right to equality, human dignity and freedom. ${ }^{30}$ The state tried to argue that extending social security to non-citizen permanent residents would create an enormous burden on the state. This argument failed in light of the fact that the additional costs would equate to two percent of the overall government expenditure on social grants. The Court held:

If a mistake is made in this regard, and the permanent resident becomes a burden, that may be a cost we have to pay for the constitutional commitment to developing a caring society, and granting socio-economic rights to all who make their homes here. ${ }^{31}$

The Court felt that the appropriate remedy would be to read the words 'or permanent residents' into the provision in question. ${ }^{32}$

\subsubsection{Concerns regarding the judgment in Khosa}

This judgement has been subject to criticism. The respondents averred that the exclusion of permanent residents was consistent with the immigration policy of South Africa. They claimed that the immigration policy 'seeks to exclude persons who may become a burden on the state and thereby to encourage self-sufficiency among foreign nationals.' 33 These averments were echoed by Alexander Graser. With reference to the minority judgement, Graser expressed three areas of concern. Firstly, he feared that the social security system would be unduly burdened by the extra costs. Secondly, the increased availability of access to social security would act as a magnet pulling more permanent residents into the country, thereby increasing the burden even more. He referred to this as the 'welfare magnet argument'. Thirdly, Graser feared that the current level of

29 Paras 46-47.

30 Government of the Republic of South Africa \& Others $v$ Grootboom \& Others 2000 11 BCLR 1169 (CC); socio-economic rights in the Constitution were said to be closely linked to the fundamental values of human dignity, equality and freedom.

31 Para 65.

32 It was also held that sec 28(1)(c) of the Constitution would be violated should disadvantaged children be excluded from the scope of social assistance due to their parent's nationality. The United Nations Convention on the Rights of the Child (1989) as ratified by South Africa places an obligation on South Africa to provide access to social security to disadvantaged children.

Para 63. 
benefits would decrease as a result of the increased burden on the welfare budget. ${ }^{34}$

The majority judgement dealt with the first issue by concluding that the respondents were unable to present an exact number of noncitizens who currently fell within permanent resident status or the number that would be eligible for social assistance. The Court also estimated that the additional costs would amount to a small percentage of the overall government spending as mentioned above. The second issue has been referenced to in similar proceedings internationally, for example Germany ${ }^{35}$ and the United States of America (US). After the 1969 ruling of the Supreme Court in the US ${ }^{36}$ certain welfare benefits were extended to migrants from other states within the US. A fear arose that more generous states would become a magnet for beneficiaries. Predictably, the benefit levels decreased but the insignificant number of interstate migrants that were eligible for the welfare benefits resulted in negligible migration. The 'welfare magnet argument' appeared to have failed in this case. The third issue can be addressed by referring to the condition for entitlement to social assistance. The South African government would retain control regarding the number of non-citizens who qualify as permanent residents and in this way would have a measure of control over the possible increase in welfare spending. ${ }^{37}$

\subsubsection{The limitation of socio-economic rights and the role of section 36 of the Constitution}

In Soobramoney $v$ Minister of Health, Kwazulu-Natal ${ }^{38}$ the Court acknowledged that:

We live in a society in which there are great disparities in wealth. Millions of people are living in deplorable conditions and in great poverty. There is a high level of unemployment, inadequate social security, and many do not have access to clean water or to adequate health care services. ${ }^{39}$

The majority reiterated the commitment made in the preamble of the Constitution to '[i]mprove the quality of life for all citizens." 40 This

34 A Graser ' Taking inclusion seriously, An outside perspective on Khosa and Others $\checkmark$ Minister of Social Development and Others; Mahlaule and Others v Minister of Social Development and Others (decision of the Constitutional Court of South Africa)' in U Becker \& MP Olivier (eds) Access to social security for non-citizens and informal workers: An international, South Africa and German perspective (2008) 163.

35 German Constitutional Court (BverfG) Decision of 6 July 2004 case numbers (Az.): 1 BvL 4/97 1 BvL 5/97 1 BvL 6/97.

Shapiro $v$ Thompson 394 US 618 (1969).

Becker \& Olivier (n 10 above) 165 - 169.

19981 SA 765 (CC).

Para 8.

Para 9. 
may be an indication that when it comes to the progression of realisation of socio-economic rights citizens will be treated more favourably than non-citizens even though these rights, in principle, apply to 'everyone'. 41

Professor Liebenberg advocates for the necessity of utilising the general limitations clause analysis when dealing with the socioeconomic rights. Liebenberg's views regarding the limitation of a right are relevant within the context of the Khosa case. Liebenberg feels that the justification for the limitation of a right by the state should not be solely based on convenience, cost-saving or a reprioritisation of resources. It is argued that to permit these grounds as sufficient justification for limitation would result in the rights becoming devoid of all effect. The state would have to show that due to limited resources the limitation is required for the sake of general welfare in a democratic society based on human dignity, equality and freedom. ${ }^{42}$

\section{The European Union perspective: from citizenship to legal residence as a requirement}

\subsection{Access to social security for non-European Union citizens}

The European Union (EU) has adopted a similar attitude to the one set out in the Khosa judgement with regards to a more inclusive social security system. Citizenship as a sole requirement is no longer regarded as appropriate for the exclusion of certain persons from their right of access to social security. Consequently, citizen tests are no longer acceptable and there has been a movement towards a legal residence criteria. It is not clear what is meant by this concept but it appears as though 'legal residence' would extend the right of access to social security further than that of the Khosa judgement since it is not restricted to permanent legal residence only. ${ }^{43}$ The exclusion of certain individuals from the South African social security system must pass the constitutional test of reasonableness. The consideration of international law and foreign law could potentially assist courts in this evaluation.

41 M Pieterse 'Foreigners and socio-economic rights: Legal entitlements or wishful thinking?' (2000) 63 Tydskrif vir Hedendaagse Romeins-Hollandse Reg 5159.

42 S Liebenberg 'Violation of socio-economic rights: The role of the South African Human Rights Commission' in $\mathrm{P}$ Andrews \& $\mathrm{S}$ Ellmann (eds) The post-apartheid constitutions: Perspectives on South Africa's basic law (2001) 405424.

43 Olivier (n 21 above) 55. 


\subsubsection{European Court of Human Rights - jurisprudence}

The European Court of Human Rights (ECHR) decision in Gaygusuz v. Austria (Gaygusuz case) ${ }^{44}$ demonstrates the more inclusive approach mentioned above. The applicant was a Turkish national who had been living and working in Austria. When he became unemployed he qualified for an unemployment benefit. After the expiry of this benefit he approached the Arbeitsamt in Linz for emergency assistance. His case was brought before the Court of Human Rights after his claim was rejected on the single basis that he lacked Austrian nationality. The applicant relied on the non-discrimination clause in article 14 of the European Convention on Human Rights accompanied by article 1 of the First Protocol. ${ }^{45}$ Unequal treatment would only be tolerated if objective and reasonable justification could be presented. The Court ruled that since the applicant had lived legally in Austria and had paid contributions, the refusal to grant him emergency assistance was a violation of article 14 of the European Convention on Human Rights. In the ECHR case of Koua Poirrez $v$ France (Koua Poirrez case), a social assistance allowance for disabled persons was denied by French authorities to a disabled, adopted child of Ivory Coast nationality due to his nationality. ${ }^{46}$ The ECHR concluded that this allowance fell within the ambit of the First Protocol. The refusal of the grant was thus regarded as unjustified discrimination.

\subsubsection{The legal residence test}

The current trend seems to indicate that the citizen test has been rejected and a more inclusive legal residence test is being adopted. In the European Court of Justice case of Sürül $v$ Bundesanstalt für Arbeit ${ }^{47}$ a Turkish woman permitted to stay in Germany in accordance with the immigration law did not possess a regular residence permit. The Court made reference to the association regime that existed between Turkey and the EU. According to this the denial of family allowances to Turkish nationals who are legally residing within an EU member state would be in violation of the principle of equal treatment. In both Gaygusuz and Koua Poirrez the Courts specifically made reference to the legal residence of the claimants in their host states. The concept of legal residence is also often expressly referred to in recently adopted international instruments guaranteeing equality of treatment and the right to social security. This is demonstrated in article 34(2) the Charter of Fundamental Rights of

(1997) 23 EHRR 364.

ETS 5; 213 UNTS 221

$40892 / 98$.

ECJ 4 May 1999, case 262/96, ECR 1999, 1210. 
the European Union, ${ }^{48}$ which refers to the right to social security for migrants travelling and moving within European territory. ${ }^{49}$

It would be erroneous to conclude that in Europe non-citizen migrants with temporary resident status enjoy complete access to social assistance. Temporary residents are admitted only if they meet the criteria of possessing sufficient means of subsistence and refrain from becoming a burden on public funds. Only those who reside legally within the state will be eligible for social assistance. Consequently, temporary residents with insufficient means may find themselves losing their residence status. This scenario would then exclude them from the right to social assistance. What can be safely concluded is that the European approach appears to tolerate the exclusion of non-citizens from social security systems should they lack a proper residence title under the relevant immigration law. ${ }^{50}$

\subsection{Access to social security for EU-citizens}

The EU is a valuable subject for a comparative study in that coordination has been established between the member states despite the diversity in their individual social security systems. EU citizens are entitled to complete and equal protection where social security is concerned and it is prohibited to treat EU citizens less favourably than national citizens. Complete access to social security includes access to benefits and insurances that are prohibited from being subject to nationality tests or any test that could be regarded as being indirect discrimination towards non-nationals. Certain exceptions must be noted. No access to social assistance is guaranteed, inter alia, where sufficient means of subsistence is a condition upon which the legality of residence is dependent. ${ }^{51}$ EU-nationals enjoy complete access to social assistance on condition that they possess permanent residence status. This status can be acquired after five years of residence.

Regulation (EEC) No $1408 / 71^{52}$ deals with the co-ordination of social security schemes and protects the social security rights of migrants with regards to social insurance and non-contributory benefits (excluding social assistance). This regulation applies to certain non-EU citizens as well. ${ }^{53}$ This means that non-EU citizens

487 December 2000.

49 Art 34(2) of the Charter: 'Everyone residing and moving legally within the European Union is entitled to social security benefits, and social advantages in accordance with Community law and practices'.

50 Olivier (n 21 above) $53-56$.

51 See Art 24(2) of Directive 2004/38/EC.

$52 \mathrm{~L} 149$ of 5 July 1971 . This regulation has been replaced by Regulation (EC) No $883 / 2004$ which came into effect on 1 May 2010. European Economic Area countries have not agreed to the new regulation. The new regulation will also not apply to third country nationals (i.e. non-European Economic Area).

53 See Art. 2 of the regulation which states which persons are covered by the regulation. 
moving within the Union are treated equally to EU citizens. This regulation does not cover third country nationals who have migrated to one member state without then continuing on to another member state. Therefore, this regulation applies in an intra-community manner. ${ }^{54}$ A similar approach can be found in article 34(2) the Charter of Fundamental Rights of the European Union.

\section{How the South African social security system can be improved}

\subsection{The introduction of a means of subsistence test}

In a recommendation to the South African Treasury Olivier suggested that the relevant legislative and administrative measures be taken to introduce a more European attitude to the granting of residence status. A means of subsistence test should be incorporated into immigration law to which the acquisition of a temporary or permanent residence permit should be subject. Should there be a failure to continue to meet the means of subsistence test the temporary permit should be withdrawn. As a result all lawful residents who have refrained from becoming a burden on the state will have enhanced access to social assistance grants. According to Olivier this should not have any significant repercussions for the South African Budget. ${ }^{55}$

\subsection{Southern African Development Community instruments ${ }^{56}$}

Regional agreements are key to achieving the level of co-ordination found in the EU. However, regional instruments can prove problematic for South Africa in the Southern African Development Community (SADC). There is inconsistency among the countries involved regarding economic and political stability and the quality of the social security systems. Consensus between the parties involved regarding fundamental values and minimum standards of social protection are essential to improving regional social security protection. Even though the SADC is a regional organisation and not a supra-national institution like the EU, similar principles seem to have been acknowledged and incorporated by the SADC for the improvement of social security protection on a regional level. The adoption of the principles set out in Regulation 1408/71 would assist in the equal treatment of citizens and non-citizens in SADC countries

Olivier (n 21 above) 53.

n 21 above 3.

For a comprehensive evaluation on access to social security within the SADC see $M$ Olivier 'Enhancing access to South African social security benefits by SADC citizens: The need to improve bilateral agreements within a multilateral framework' (2011) 1 SADC Law Journal 121. 
and would allow for the reaching of a consensus on certain vital principles. 57

It has been suggested that the status of SADC member states' citizens regarding social security should be developed in line with SADC goals of regional integration and unity. Policies should be developed where minimum standards for social protection of groups of beneficiaries are established, on the grounds of equality within the SADC regardless of citizenship status. ${ }^{58}$ Regional instruments such as the SADC Treaty and the Charter of Fundamental Social Rights in SADC have encouraged the establishment of a system of social security coverage for citizens of the different member states. These instruments impose a duty of member states to provide adequate social protection to workers in the region ${ }^{59}$ in the absence of a distinction between citizens and non-citizens. The Code on Social Security (2007) states that 'Everyone in SADC has the right to social security'.60 Social security in this case includes social insurance, social assistance and social allowances. It further states that

Everyone in SADC who has insufficient means of subsistence to support themselves and their dependents should be entitled to social assistance, in accordance with the level of socio-economic development in the particular Member State. ${ }^{61}$

This is a progressive step in the realisation of the right to social security for everyone within the region. South Africa is yet to fully make use of potential cross-border co-ordination arrangements to regulate the migration of citizens within the SADC. It has been argued that pure reciprocal arrangements similar to that found in the Social Assistance Act are inadequate when it comes to effectively regulating the position of migrating citizens of member states. ${ }^{62}$ Effective national legislation and multilateral arrangements will need to be adopted in order to ensure regional coverage and protection of social insurance benefits. This will assist in, not only, providing social security protection to migrant workers within the borders of SA but also migrant SA workers finding themselves away from home.

\subsection{The approach of the Courts}

The South African courts are empowered through section 38 of the Constitution to grant appropriate relief in situations where rights as enshrined in the Bill of Rights have been violated. Section 39(1)

R Holzman et al 'Portability Regimes of Pension and Health Care Benefits for International Migrants: An Analysis of Issues and Good Practices' (2005) 4 Social Protection Discussion 4 - 5.

58 Olivier (n 21 above) 72 - 73.

59 Art 10.1 of the Charter of Fundamental Social Rights in SADC.

60 Art 4.1.

61 Art 5.1.

62 Olivier (n 21 above) 72. 
requires that courts consider both international and foreign law when interpreting the Bill of Rights. When examining the international approach towards providing access to social security for non-citizens it would appear as though the position of South African courts falls short of broader international law standards where discrimination based on national or social origin constitutes a violation of human rights. ${ }^{63}$ This being said, it must be taken into account that certain international instruments provide flexibility for states to exclude certain groups of non-citizens in accordance with their resources and immigration policies. ${ }^{64}$ It was suggested that social assistance grants be made available to all lawful residents who have refrained from becoming a burden on the state. ${ }^{65}$ Although the Khosa judgement has directed the scope of access to social assistance in this direction, it is limited to permanent residents only, which is a less inclusive standard than the 'legally resident test' found in the EU. It may, at first, appear as though the South African courts have adopted a less liberal approach than countries who subscribe to the 'legally resident test'. However, when the access to social security for non-permanent residents is investigated, the potential risk of limited access exists as a result of the means of subsistence test in immigration law. ${ }^{66}$ In light of this, the position of the South African Constitutional Court is not completely out of line with the approach in other constitutional democracies.

\section{Conclusion}

The South African Bill of Rights expressly acknowledges the rights of 'all people in our country'. The state is obliged to progressively promote these rights, amongst them, the right of access to social security which applies to everyone despite the limitations of scarcity of resources and the general limitations clause. Yet, non-citizens have found themselves excluded from certain social security benefits. The Constitutional Court has extended the scope of social assistance benefits to permanent residents, but has also found that it may be reasonable to exclude certain non-citizens from these benefits. The fears of an increased burden on the current social security system and the 'welfare magnet argument' are legitimate government concerns that pose a threat to the extension of access to social security. With many adopting a 'charity should begin at home' attitude, the state is urged to respect the fundamental rights of all people within the

Art 2 of the Universal Declaration of Human Rights (1948).

See para 3.

Olivier (n 21 above) 3.

Olivier (n 21 above) 70 . 
Republic but not at the expense of the citizens of South Africa. ${ }^{67}$ The legitimacy of these fears appear to be declining with time as occurrences in both South Africa and abroad do not seem to support them.

It is clear in both South Africa and the EU that the sole requirement of citizenship for access to social security is no longer acceptable. A movement towards a more inclusive legal residence criteria is being adopted throughout Europe. The equal treatment of citizens from other SADC member states will most certainly assist in alleviating the plight of non-citizens. It will also ensure the portability of benefits and assist non-citizens in enforcing their rights. Although the EU differs from the SADC economically speaking, the principles forming the basis of the EU social security approach is sound and could assist South Africa in bringing about the necessary reforms and extension of access to social security.

Although the Khosa judgment has taken steps in the right direction it appears as though the courts in the EU have adopted a more liberal and inclusive attitude towards the position of noncitizens. Poverty and exclusion pose a threat to the rights and freedoms of many individuals. Consequently, the intervention of courts and other enforcement organisations and institutions must ensure the right to equality, human dignity and access to social security of non-citizens. Courts will also play an important role in interpreting both international and regional standards. The Constitutional Court has a duty to ensure that the values and objectives of the Constitution are upheld and legislative restrictions barring the enjoyment of social security benefits by everyone may need to be re-examined in order to ensure that the state complies with its duties under section 27 of the Constitution and international law standards. After all, charity may begin - but it certainly does not end - at home. ${ }^{68}$

67 GM Letlhokwa'Charity begins - but does not end - at home - Khosa $v$ Minister of Social Development; Mahlaule v Minister of Social Development 20046 BCLR 569 (CC)' (2005) 26 Obiter 173 \& 186.

Lethlokwa (n 67 above) 173. 


\title{
POST-APARTHEID REFLECTIONS ON CRITIQUE, TRANSFORMATION AND REFUSAL
}

by Joel SM Modiri*

\author{
Introduce a little anarchy \\ Upset the established order \\ And everything becomes chaos. \\ (The Joker $)^{1}$
}

\section{Introduction: Refusal in snapshots}

In this article I engage with the notion of refusal, as introduced by Karin Van Marle, to post-apartheid jurisprudence as a way through which to think of life, death, law and politics against the backdrop of poverty, social misery, disease, oppression and prejudice. ${ }^{2}$ She proposes that we consider refusal firstly as a possible mode of critical thinking and theorising but ultimately also as an alternative approach to law and jurisprudence. ${ }^{3}$ For Van Marle, what lies at the heart of refusal is the 'idea of unexpectedness that breaks with the formality and predictability of law'4 - an unexpectedness that could disclose new directions for thinking about and doing law. In Van Marle's own words:

The project on refusal and risk within the South African post-apartheid context involves a rethinking of the prevalent ideas on transformation, transformative constitutionalism and law. The aim is to call for a refusal of instrumental reliances on knowledge. Refusal is an action in the limit, action imbued with reflection. A risking law arises because of the refusal traditional and unreflective approaches. ${ }^{5}$

* Second year LLB, University of Pretoria. I am grateful to Karin van Marle for her continued support, mentorship and encouragement. I am also grateful to Isolde de Villiers for her thoughtful and incisive comments on this piece - in the process helping me to clarify my thoughts and improve the form and substance of this article. Many of the thoughts shared in this paper have greatly benefitted from discussions with Duard Kleyn, Albie Sachs, Dennis Davis, Pierre de Vos, Drucilla Cornell, Christof Heyns and Stu Woolman. Finally, I want to thank Petronella Kruger, Alfred Moraka and Serena Kalbskopf for always pressing me to think deeper and differently about life and law.

1 Christopher Nolan (dir.) The dark knight (2008).

2 K van Marle 'Laughter, refusal, friendship: thoughts on a "jurisprudence of generosity"' (2007) 18 Stellenbosch Law Review 194. See the book review: M Slabbert \& APJ Roux 'Human rights concern much more than only racial differences and discrimination' (2010) 75 Koers: Bulletin for Christian scholarship $683-688$

3 K van Marle 'Introduction: refusal, risk, liminality' in K van Marle (ed) Refusal, transition and post-apartheid law (2009) 13.

4 n 3 above, 1.

5 n 3 above, 13. 
As a point of departure, perhaps an intriguing aspect of the notion of refusal is its presentation. Both Wessel Le Roux ${ }^{6}$ and Stu Woolman ${ }^{7}$ note how, in conceptualising the notion of refusal, Van Marle resolutely turns away from conventional, pedantic legal writing styles. It is indeed the avoidance of gratuitous over-quoting of 'legal' sources, the absence of mechanical and uninspired interpretations, and the defiant and critical treatment of the pervasive institutions of law and human rights that makes refusal such a compelling notion. In refusing to write in the dry, doctrinal and masculine style expected of law professors, Van Marle beckons the first of many acts of refusal.

Refusal provides a new model for theorising and thinking about issues of transformation, reconciliation and inequality in ways that are radically different to, and critical of, formalist and liberal approaches that operate within the strict economy of law and human rights. In this way, it offers alternative perspectives on human agency, subjectivity and life under law in the 'new' South Africa. It displaces the hegemonic order, 'setting up an impenetrable distance between that order and itself.' 8 follows: ${ }^{9}$

The importance of considering refusal is set out by Van Marle as

In South Africa it seems as if transformation, socio-economic reparation and other social problems like poverty, violence and disease are addressed mostly through law and human rights. But, as is often argued and exposed, law and human rights are lacking in the capacity to effect real change. How can we find different ways to approach these issues in the face of the pervasiveness of law and human rights? I would like to ... ask ... to what extent the "public" face of the new legal order (human rights and constitutionalism) is translated into the "private".

In my view, refusal marks a major shift in legal theory, primarily because of its concern with the possibilities and simultaneous impossibilities of another political community, another law and a more egalitarian set of relationships between people. Situated within a post-apartheid context, refusal opens up legal discourses to social, political, and ethical issues in people's day-to-day lives. Woolman highlights two aspects of refusal that are significant for this discussion: ${ }^{10}$

First, genuine reformation is more likely to be found in the day-to-day interactions and relationships that take place beyond the law, beyond normal politics and beyond revolution. Secondly, it is a perfectly

W Le Roux 'Six (individually-named) notes on the counter-aesthetics of refusal' in Van Marle (ed) (n 3 above) 58.

7 S Woolman 'On rights, rules and relationships: a reply to Van Marle's "jurisprudence of generosity"' (2007) 18 Stellenbosch Law Review 508.

8 A Cavarero In spite of Plato: A feminist rewriting of ancient philosophy (1995) 17.

9 n 2 above, 194

10 n 7 above, 516. 
reasonable response to the world as it is to turn away from law, politics and revolution - because they have failed to deliver - and to embrace 'solitude' - and a refusal to give the processes of law, politics and revolution our tacit imprimatur of approval.

It was in fact Woolman who coined the term 'ethic of refusal' to describe the objects of Van Marle's jurisprudential project. At the core of this ethic is a concern with context and particularity, ${ }^{11}$ with 'embodiedness' and 'embededness,' 12 and with voices previously silenced and excluded from the public space. Van Marle eschews liberal, elitist and positivistic accounts of law and draws from the worlds of politics, philosophy, literary criticism and film theory to warn of the dangers of the over-enthusiastic embrace of and trust in law and human rights.

After reading and re-reading Van Marle's thoughts on refusal, it is easy to come away with the impression that she is flirting with a nihilistic, defeatist idea of law. Admittedly, that would be a plausible reading but also an unreflective and inattentive reading. To my mind, refusal does not refuse law; it challenges lawyers, scholars and judges to take risks - it thus refuses only a risk-free, predictable, mainstream conception of law.

Refusal calls for a risking law - one that refuses cautious modes of analysis and takes bold risks, experiments with possibilities and new approaches, and goes beyond expected confines in order to address the 'position of a concrete embodied person ...'. ${ }^{13}$ A risking law is one that is undaunted by being faithful to a certain notion of analytical rigour, theoretical analysis and interpretive tradition.

The connection between risk and law is highlighted in Karl Klare's call for the refusal of formalist approaches to legal interpretation and his urging of legal practitioners, academics and judges to take up the challenge of 'transformative constitutionalism': ${ }^{14}$

The New South Africa has a Constitution with massively egalitarian commitments superimposed on a formalistic legal culture without a strong tradition of substantive political discussion and contestation through the medium of legal discourses. An opening of transformation requires South African lawyers to harmonise judicial method and legal interpretation with the Constitution's substantively progressive

11 K van Marle 'Law's time, particularity and slowness' (2003) 19 South African Journal on Human Rights 245.

$12 \mathrm{~K}$ van Marle 'The universe is made of stories not atoms' (2000) 2 Phronimon 346. For these purposes 'embodiedness' refers to a certain completeness that all human beings should enjoy through freedom, agency and moral sovereignty. 'Embeddedness' refers to a rootedness and individual selfhood that comes from one's identification with and membership within a specific community/ies.

$13 \mathrm{~K}$ van Marle 'Transformative constitutionalism as/and critique' (2009) 20 Stellenbosch Law Review 291.

14 K Klare 'Legal culture and transformative constitutionalism' (1998) 14 South African Journal on Human Rights 188. 
aspirations. The burden of my argument is that law and legal practices can be a foundation of democratic and responsive social transformation, but that this requires us to evolve an updated, politicised account of the rule of law.

This challenge demands that we refuse the continuance of the apartheid legal culture. If we fail to take up this challenge, the Constitution, and all the concomitant theoretical perspectives and modes of legal reasoning meant to support it, will remain a vicious rumour to the black people who are caught up in the structural violence of poverty and dispossession; to the women who are trapped in abusive marriages and terrorised by rapes and harassment; to the poor communities with no access to clean running water; to the hungry and homeless without food and blankets in the cold winters; to the children who don't go to school and to the refugees who are beaten, violently deported and killed every year in South Africa. Refusal, in this context, could then be understood as taking up Klare's challenge of transformative constitutionalism. In fact, I would suggest that when read together, Van Marle's ethics of refusal and Klare's transformative constitutionalism make another point: they argue for an approach (or approaches) that acknowledges and works with the deeply political and ideological underpinnings of law; that can counter and enhance the business-as-usual mindset of the postapartheid legal community.

As can be seen from the introduction above, refusal is a loaded and complex concept. It can be understood in many ways and interpreted from many different angles. It has many contingent meanings and holds multiple possibilities for political thought and action. In what follows, I reflect on these meanings and possibilities. A comprehensive summary of Van Marle's article is not provided because I proceed from the assumption that the reader is familiar with the article and/or book on refusal. ${ }^{15}$ Where this assumption is misplaced, readers are urged to read the article. The aspects highlighted here may not necessarily be the most important aspects for others. The arguments in this article will be framed around three signal forms of refusal: (1) 'refusal as critique' discusses refusal a critical approach to law and legal theory; (2) 'refusal as limit and possibility' explores how by engaging with the limits of law, refusal beckons alternative approaches and new possibilities and (3) 'refusal as performative' examines the role of citizens and social movements in enacting their own refusals and practices of resistance against hegemonic meanings and institutions (such as law, capitalism etc). This article offers no easy answers or facile solutions and does not claim to have a prophetic comprehension of the meaning, demands and objects of an ethic of refusal. Instead, an attempt is made to 
briefly sketch the key themes and animating features of refusal and contribute to an authentic discourse on law, human agency and critique.

\section{Writing refusal - refusal as critique}

The notion of refusal can quite plausibly be read as a postscript to and side-effect of Van Marle's earlier writing on (the absence of) 'action, thinking and revolt ...'. ${ }^{16}$ The crux of Van Marle's argument and the anchor of her scholarship is that South African society is characterised by an overwhelming over-reliance on law, human rights and constitutional discourse. As a result, this has lead to a dire absence of conscious political action, ethical thought and critical revolt within politics, law and critique. Law is not politics precisely because it is unable to contain political action and revolt. ${ }^{17}$ Refusal is thus an 'ethical engagement with the limits of law' 18 and invites politics, risk and liminality.

Admittedly, the sometimes thick soup of Van Marle's metaphysical prose is not for the faint-hearted, nor is it for the dogmatic and uncritical. It is for those who, in the present climate of constitutional optimism and an unquestioning faith in the rule of law, still dare to allow some scepticism and radical critique to break into flight and disrupt legal discourses in ways that expose the conservative, patriarchal, and white supremacist underpinnings of those discourses. Seeking to critically articulate her frustrations with a society overtaken by the grand-narrative of the Constitution and a proceduralised and institutionalised human rights system, Van Marle challenges Christof Heyns' struggle theory of human rights. With this critical review of Heyns' theory, Van Marle wanted to show: ${ }^{19}$

$[T]$ he reductions that occur when coupling politics with law (struggle with rights) and humanity and human life with legitimacy (human with legitimate). In close proximity to the above is also the ethical notion of responsibility that is reduced to a mere instrumental responsibility that corresponds with rights. Ultimately I lament that passion and the passion of the moment is limited and reduced to a tempered passion.

Van Marle 'Lives of action, thinking and revolt $-\mathrm{a}$ feminist call for politics and becoming in post-apartheid South Africa' (2004) 19 SA Public Law 572-604.

17 Van Marle \& Le Roux 'Introduction' in Van Marle \& Le Roux (eds) Post-apartheid fragments: law, politics and critique (2007) xii - xiii. This claim is also made by E Christodoulidis 'The suspect intimacy between law and political community' (1994) 80 Archiv für Rechts- und Sozialphilosophie 1-18 and J van der Walt 'The (im)possibility of two together when it matters' (2002) Journal of South African Law 462-477.

18 n 17 above, xiii.

19 n 16 above, 616 
For Heyns, '[o]ne way of looking at human rights is to see it as the flipside of the coin of legitimate resistance ...' ${ }^{20}$ He concretises this idea in the expression 'human rights/legitimate resistance' and 'legitimate resistance/human rights. ${ }^{21}$ Heyns, in what appears as an attempt to formulate a populist account of human rights, argues that 'behind human rights claims there is the possibility, if there are no reasonable alternatives, of resorting to self-help; and conversely, that for self-help to be legitimate ...' 22 Heyns contends that 'human rights serve as a countervailing force against state power' and that it is specifically its strong association with resistance that gives human rights such force and legitimacy. ${ }^{23}$

In terms of the struggle theory, rather than thinking of 'law [as] a command of a sovereign, backed by a threat' as was said by the positivist John Austin, it is better to think of 'human rights claims as demands of citizens, backed by a threat'- the threat of self-help; the threat of (legitimate) resistance; the threat of refusal to obey. ${ }^{24}$ In view of that, the bold assertion 25

... that rights are 'inalienable' does not imply that they cannot be taken away, but rather that should they be alienated they may be 'taken back', either by those whose rights have been violated or by others on their behalf.

Human rights, Heyns argues, are 'guides to action and triggers of resistance' and 'as such, human rights has a potentially revolutionary dimension ...'26 This revolutionary element is evidenced by the worldwide clampdown by authoritarian regimes on human rights activists.

It is Heyns' contention that human rights do not rely on recognition by the state - they are in fact minimum conditions for the existence of a state. If a state fails to protect the rights that are at the core of human existence, the duty to obey the state lapses, thus exterminating the very functioning of law: a balance between state power and civil compliance with state laws. ${ }^{27}$

He explains the foundation of or the reason for human rights as the 'common sense resolution' to 'never repeat the mistakes of the past ...' ${ }^{28}$ Consequently, the 'morality' of human rights is merely 'an attempt at long term rationality ...'.29 For him, 'practice underlies 
theory - not the other way around.' Historical events and human rights documents that contain the right to resistance are presented as proof of the struggle theory's credibility: the Magna Carta of 1215, John Locke's defence of the 'Glorious Revolution' of 1688, and the American Declaration of Independence of $1776 .{ }^{30}$ Accordingly, human rights are the 'ultimate guarantor of popular sovereignty ...'31 Bringing his arguments back to a South African context, Heyns finds resonance with his theory in Mahatma Gandhis' satyagraha (civil disobedience) and Nelson Mandela's words: 'the struggle is my life ...'32 He points to the Freedom Charter as 'the document that more than any other serves as a 'codification' of the struggle' and to the 1996 Constitution of South Africa as 'the culmination of the struggle.' 33 The above briefly captures some of the main tenets of the theory that 'human rights = legitimate resistance'.

As is clear here, the struggle theory is also concerned with the power and meaning of refusal in a different form - perhaps one which is more legalist and technical. In terms of the struggle theory, one can refuse to obey the law and refuse to do that which goes against one's 'fighting causes' or 'core interests' (such as the shared beliefs and values in a community or nation). The difference and problem is that the struggle theory is conditional and limited to attacks on conscience, infringement of first-generation rights and unacceptable material living conditions.

Struggle, civil disobedience and Heyns' conception of refusal can be allowed only in 'extreme cases' where it is 'justified' based on 'empirical evidence' whereas Van Marle's conception is open to all acts of refusal in the public and private sphere, in law and in politics. Van Marle, following Hannah Arendt and Julia Kristeva, is more concerned with constant questioning, political action, reflective thought and contestation of a non-violent but critical, lively and dialogical nature. Indeed, it is easy and natural in the present world context to become indifferent to and despondent about the interpretation and application of human rights. Not only have the greatest human rights violations taken (and continue to take) place in our time, but human rights have also lost their 'critical edge' by becoming the tool of governments and international organisations. ${ }^{34}$

Van Marle regards the main problem of the struggle theory to be its very grandiose style of argumentation. This is seen in the struggle theory's declaration to provide the 'ultimate foundation and explanation for human rights' and its claim to be able to settle all current and future tensions, debates and protestations on human

n 20 above, 17-20.

n 20 above, 17.

n 20 above, 22.

n 20 above, 21-22.

C Douzinas The end of human rights (2000). 
rights. ${ }^{35}$ Another point of critique is the strong emphasis Heyns places on a formal notion of legitimacy, as well as his heavy reliance on mostly Western history.

For Van Marle, the struggle theory 'relies on a modernist acceptance of rationality and human reason' and 'follows an abstract form of agency ...' ${ }^{36}$ Van Marle's uneasiness with the struggle theory is that it assumes a single history and asserts the possibility (and perhaps desirability) of 'one universal truth ...'37 Following Jean-Luc Nancy and Arendt, Van Marle contends that '[h]uman rights should be seen as a form of action, not a set of moral truths ...' 38 In her view, ' $[\mathrm{t}] \mathrm{o}$ concentrate on rights that are attached to politically passive and invisible legal subjects could lead to misdirection in our resistance to totalitarianism ...' ${ }^{39}$ In Van Marle's view, this 'is not true to the Arendtian tradition of active politics and the centrality of life and narrative ...' 40 This claim is supported in Arendt's conception of 'totalitarian lawfulness', which as Le Roux mentions, 'defines itself by the open defiance of positive laws and petty legality in favour of the direct reign of justice on earth. ${ }^{41}$ She questions how the struggle theory differs from natural law explanations for the origins of, and justification for, human rights. Still, Van Marle's bone of contention with the struggle theory is with its inability to contain, or even facilitate, post-apartheid politics because of its concern with reason, logic and rational knowledge. Further, according to the struggle theory, the eventual codification of human rights in international treaties and conventions and the entrenchment of human rights in domestic Constitutions marks the 'end of political struggle rather than its beginning.' 42 In this way, the possibilities for meaningful struggle and active and continuous politics is diluted, and perhaps even negated, by requirements of legitimacy and validation.

[T] he translation of struggle into rights, humanity into legitimacy, and politics, thinking and narrative into an economy of the private, puts a damper on action, thinking and revolt and a politics of becoming. ${ }^{43}$

Although it hints at the potential becoming of a politics of refusal, the struggle theory closes the space for refusal because the existence of law and human rights makes self-help (resistance and also, struggle

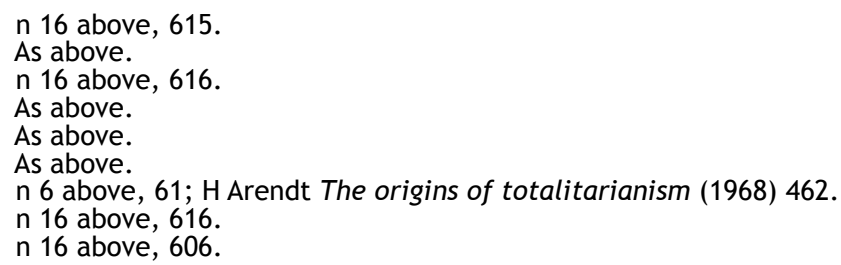


and revolt) 'unnecessary." 44 An example of where human rights do not circumvent hegemonic state power and control and, in fact, support it is the recent service delivery protests, wage strikes and activist efforts against privatisation of basic services in South Africa which are often met with arrests, police brutality, tear gas, water cannons and rubber bullets. Petitioners and demonstrators at international conferences like the G8, the World Summit on Sustainable Development and the World Economic Forum are also met with threats and repressive tactics. By setting the parameters for legitimate struggle so thinly, the struggle theory runs the risk of aligning itself with powerful governments, capitalist interests and elite international agencies and not with poor, disenfranchised and alienated citizens as it purports to do. When political dissent is defined within the confines of the "rule of law", all forms of struggle are negated.

The triumphalism in Heyns' belief that a set of positive laws, a collection of words, rules and promises (going by the name of 'human rights') can bring peace and prosperity, end all struggles and suffering, also causes great uneasiness. Indeed the struggle theory might have resonance and relevance in China or North Korea (and most recently in Tunisia, Egypt and Libya) but in South Africa, it is misleading to make people who are still hungry and homeless believe that human rights will feed them and give them shelter - especially

Heyns (n 19 above) 17. I tend to share much of the uneasiness expressed by Van Marle and also by Isolde de Villiers about the struggle theory and human rights in general. De Villiers, following Jennifer Nedelsky argues that rights are too individualistic, they obfuscate the real political issues at stake and serve only to alienate and distance people from one another (in Heyns' theory, even an individual can claim the right of self-help and more curiously, a judge can rule against a collective majority in favour of a 'longer term' conception of majority). I am interested in the struggle theory because it attempts to redeem law and human rights by moving human rights discourses out of the strict domain of law to an in-between space between 'people on the ground' (politics and the political) and the 'powers that be' (law and legality). But I am sceptical of it because I do not see how it can facilitate or support post-apartheid struggles for dignity, recognition and equality and also why a notion that could be seen as supporting anarchy would simultaneously be tethered to the argument that 'the coming' of human rights makes struggle, contestation and self-help unnecessary. I am concerned at how human passion, struggle and agency is framed strictly in terms of law and human rights. By using Mandela's words 'the struggle is my life' as part of his argument, Heyns seems to be saying that the need for and importance of the legal concept of human rights is what animated the defiance campaign and other revolutionary struggles against the racist apartheid regime, thus negating deeply ethical, political and social dimensions of the anti-apartheid movement. To my mind there is more at stake in any struggle than the eventual entrenchment of a set of rules. Requirements for legitimacy, emphases on rationality and tempered passion and the reliance on western and even Christian history lead me to conclude that the actual summary of the struggle theory is: human rights (sometimes) = legitimate resistance (only if) ... and (but ...). See I De Villiers 'South African legal culture in transformative context', unpublished LLM dissertation, University of Pretoria, 200967 - 76 where the struggle theory is also criticised for falling into the trap of universalism, essentialism and for being reactionary in nature. 
due to the fact that human rights are caught up in the language and jargon of formal rules and legalities. The mathematics of the struggle theory is also disconcerting: the measure taken to resist the infringement of human rights must be proportional and balanced, says Heyns - the two acts (the infringement and the resistance) must (neatly) cancel each other out. ${ }^{45}$

Connected to the uneasiness with the struggle theory, are warnings against formalist and apolitical approaches to law and human rights. Klare warned against this in observing that South African lawyers, academics and judges display a:

... relatively strong faith in the precision, determinacy and selfrevealingness of words and texts. Legal interpretation in South Africa tends to be more highly structured, technicist, literal and rule-bound. ${ }^{46}$

He cautions against this, urging scholars, judges and practitioners to refuse outmoded methodologies and interpretations and rather, to embrace alternative, more critical approaches:

[C]onservatism reduces the transparency of the legal process, thereby undermining its contribution to deepening democratic culture. ${ }^{47}$

[J]urisprudential conservatism ... may induce a kind of intellectual caution that discourages appropriate constitutional innovation and leads to less generous or innovative interpretations and applications of the Constitution. ${ }^{48}$

Refusal, as it is understood here, was born out of those critical points on action, thinking and revolt. It is apt that three years later, Van Marle would formulate an updated critique based on the following words by Patrick Hannafin: 49

The right to refusal calls us to think beyond the state and our role in the biopolitical matrix. It involves a questioning of why it is that the law presumes to be in control of language. It involves a certain refusal to submit to the law, to be insubordinate. It is that other law of writing that is without foundations as opposed to the writing of law, which purports to found the community. It is a call to suspend the dialectical closure of representational politics, as well as the essential complicity of government and legal opposition deriving from it, to affirm a different kind of politics, no longer dependent on the law of possibility.

For Van Marle, at the heart of refusal is the notion of a 'jurisprudence of generosity' as espoused by critical race theorist Patricia Williams, ${ }^{50}$ which could best be exemplified by Mokgoro J's

45

46 above, 32

n 14 above, 168. See also K van Marle 'The spectacle of post-apartheid constitutionalism' (2007) 16 Griffith Law Review 411 - 429.

47 n 14 above, 171.

48 As above.

49 P Hannafin 'The writers refusal and the law's malady' (2004) 31 Journal of Law and Society 14.

$50 \quad \mathrm{P}$ Williams The alchemy of race and rights (1991). 
judgement in the Khosa ${ }^{51}$ case and Sachs J's judgement in Dikoko. ${ }^{52}$ In Khosa the Constitutional Court found that it was unconstitutional to exclude permanent residents (albeit refugees from Mozambique) from the class of persons entitled to a variety of social security grants such as old age, disability, veterans, child-support and foster care grants. The basis for this ruling was tentatively that sections 26, 27 and 28 of the Constitution use the word 'everyone' and 'every child' respectively and that as such, delimiting access to social service grants was a clear violation of the spirit, purport and objects of the Constitution. Emphasising the importance of the State taking responsibility for the Other, Mokgoro $\mathrm{J}$ writes: ${ }^{53}$

The exclusion of permanent residents in need of social-security programmes forces them into relationships of dependency upon families, friends and the community in which they live, none of whom may have agreed to sponsor the immigration of such persons to South Africa ... Apart from the undue burden that this places on those who take on this responsibility, it is likely to have a serious impact on the dignity of the permanent residents concerned who are cast in the role of supplicants.

In Dikoko, Sachs $\mathrm{J}$ took the route Van Marle and Klare seem to be calling for - a risking law that refuses jurisprudential conservatism in favour of more innovative and generous applications of the Constitution. Sachs $\mathrm{J}$ argued that the almost exclusive preoccupation with awarding monetary damages as compensation in defamation cases is incompatible with restoring the damage to a person's reputation and indeed to the parties' relationship. His view is that a defamation law that would rather encourage apology with the aim of reparation, face-to-face public encounter, and reconciliation as opposed to a punitive method would be more appropriate. Sachs J does not aim for an expedient judgment but rather attempts to repair the broken relations between the parties in the hopes that peace and happiness could become a norm in society. It is worth quoting Sachs J when he writes that: 54

There is a further and deeper problem with damages awards in defamation cases. They measure something so intrinsic to human dignity as a person's reputation and honour as if these were market place commodities. Unlike business, honour is not quoted on the Stock Exchange.

We could also turn to Port Elizabeth Municipality $v$ Various Occupiers ${ }^{55}$ for another example of a 'jurisprudence of generosity.' In $P E$ Municipality, the Court refused to grant an order for the eviction of homeless 'unlawful' occupiers of privately owned land on the basis

51 Khosa $v$ Minister of Social Development; Mahlaule $v$ Minister of Social Development 20046 BCLR 569 (CC).

Dikoko v Mokhatla 2007 (1) BCLR 1 (CC). See paras 105 and 113-15.

n 52 above, para 76.

n 52 above, para 109.

200412 BCLR 1268 (CC). 
that the occupiers had been on the land for many years and the municipality had taken insufficient and perfunctory steps to establish the circumstances of the occupiers. The land was also not needed for immediate use by the owners. The Court thus did away with the formalistic common-law right to property and rather chose to recognise the right of the 'various occupiers' not to be arbitrarily deprived of a home. Sachs $\mathrm{J}$ took notice of extra-legal phenomena in his consideration of how, during the apartheid era, illegal squatting would have been met with repression and brutality which not only brought great indignity and iniquity against black people, but also led to the undesirable creation of large affluent white suburbs that coexisted alongside poor black locations marked by poverty, and harsh social conditions. The Court, in a communitarian gesture, was at pains to emphasise that: ${ }^{56}$

[i]t is not only the dignity of the poor that is assailed when homeless people are driven from pillar to post in a desperate quest for a place where they and their families can rest their heads. Our society as $a$ whole is demeaned when state action intensifies rather than mitigates their marginalisation.

These three cases, together with rulings in, inter alia, Bhe, ${ }^{57}$ Fourie $^{58}$ and Makwanyane ${ }^{59}$ show that the Constitutional Court was animated not by a concern with a fixed understanding of dignity and equality or with rigid and technical interpretations. Instead the court focused on uBuntu, respect, intrinsic worth, 'care and concern', happiness, love, the centrality of life, and the reconciliation between 'enemies.' In other words, the courts applied an ethical interpretation of dignity and equality 'unencumbered by rules and doctrine' and paid close attention to the concrete experience and realities that impact on people and play themselves out in the legal arena. When the State said to the plaintiffs in each of the above cases that '[y]ou do not interest me', the Court refused this and acknowledged that 'no [one] can say these words without committing a cruelty and an offending against justice. ${ }^{60}$ It seems that Sachs $\mathrm{J}$ and Mokgoro $\mathrm{J}$ in these judgements also responded to Klare's call for judges to develop a politically and morally-engaged humanist form of judicial decisionmaking.

This body of case law could be said to refute Van Marle's apprehension towards law's ability to address social problems but paradoxically it also emphasises the importance of refusal, generosity and risk as modes of legal enquiry and interpretation. We are then left

56 n 55 above, para 18.

57 Bhe v Magistrate, Khayelitsha, 20051 BCLR 1 (CC).

58 Minister of Home Affairs \& Another v Fourie \& Another; Lesbian and Gay Equality Project \& Others v Minister of Home Affairs \& Others 20063 BCLR 355 (CC).

59 S v Makwanyane 19956 BCLR (CC).

60 See Simone Weil 'On human personality' in R Rees (ed) Selected essays (1962) 934. 
to wonder what the results would have been had a similar ethics and politics and concern for 'enhancing lives' also featured in the cases of, inter alia, Prince, ${ }^{61}$ Volks, ${ }^{62}$ and Jordan. ${ }^{63}$ The critique offered by refusal and its overt concern with politics, ethics and humanity is a useful antidote against narrow, logocentric and universalist theories and approaches. Scholars could employ the notion of refusal in their fight for justice, social reconciliation and transformative constitutionalism. Refusal is thus not passive or quietist, it is active and critical. It also produces tangible results when integrated into legal judgements and research agendas.

\section{Talking refusal - refusal as limit and possibility}

We are always, in a profound sense, guilty of giving too little and arriving too late. Derrida is serious when he writes that none of us is in a position to have a good conscience. ${ }^{64}$

Refusal is of course caught within its own limits. Refusing the pervasive power of positive law and institutionalised human rights does not make them any less pervasive and any less dominant. It merely circumvents their immediate power, subverts their hegemony and opens up spaces for resistance and revolt from where one could find different ways to live under law. This is the wonder and irony of refusal: by being open to its own limits and impossibilities, refusal beckons alternatives, possibilities and limitless opportunities. The notion of refusal then borrows from Drucilla Cornell's 'philosophy of the limit' (her renaming of deconstruction) to show that limits and possibilities share a very special relationship because 'what is other to our present social reality cannot be known in advance and already foreclosed by some grand theory. ${ }^{65}$ In this way, limits open the space for an as-yet unknown future.

Cornell articulates two meanings of limitation, which are suggestive for refusal and for law's potential. Firstly, 'the limit of theoretical reason' in the sense that critical philosophy understands that we can never go beyond current representations of the world as given to us by imagination and secondly, following Derrida, 'the limit of what can be known is also a condition of knowability ...' 66 She recalls Immanuel Kant's three great questions of philosophy - each of

Prince v President, Cape Law Society \& Others 20022 SA 794 (CC), 20023 BCLR 231 (CC).

62 Volks NO $v$ Robinson \& Others 20055 BCLR 446 (CC).

$63 \mathrm{~S} v$ Jordan \& Others (Sex Workers Education and Advocacy Task Force \& Others as Amici Curiae) 200211 BCLR 1117 (CC).

64 D Cornell Moral images of freedom: a future for critical theory (2008) 70.

65 n 64 above, 3.

66 n 64 above, 5. 
which is attached to some tentative hope in the future and the pursuit of an aporetic life: 'What can I know? What am I to do? What can I hope for?'67 For Cornell, hope is something that cannot be proven to be impossible and thus since we can never know what is impossible, we have to always be willing, through reflexive judgement and aesthetic ideas, to imagine and explore what might be possible. ${ }^{68}$ Hope is thus central to the notion of limit. Cornell writes: ${ }^{69}$

Limitation then actually keeps open the impossibility of knowing what is impossible, leaving certain positivistic or naturalistic conceptions of humanity incapable of concretely postulating what we hope to achieve.

An ethic of refusal is precisely aimed at keeping open those possibilities; experimenting with and pursuing them; preventing their closure by reified and uncritical approaches. Many legal scholars have attempted to expose the limits of law to achieve social change ${ }^{70}$ largely due to liberalism's rigid separation of law and politics, citizens and communities, justice and care, rights and rules. The formation and 'becoming' of the Critical Legal Studies (CLS) movement and its critique of law also exemplifies a refusal - of outdated approaches to legal pedagogy. Law students, during the troubled period the world was in when the CLS movement was formed, were clearly struck by the contrast between the law taught to them in the lecture halls and the legal and ideological tensions that were dividing nations around the world.

The gap was too wide and a deeper understanding of the nature and role of law was sought. They focused on the ways that law had contributed to illegitimate social hierarchies, producing domination of women by men, non-whites by whites and the poor by the wealthy. CLS scholars draw upon diverse intellectual currents - ranging from literature, political philosophy and history to Marxism and social theory - in order to expose the indeterminacy of legal rules, the fundamental contradiction in legal discourse and the possible impotence of rights to address social problems. ${ }^{71}$

In addition to exposing law's limits, CLS scholars also opened up the possibilities of new unconventional perspectives. The indeterminacy critique shows that more often than not, a judge (and

67 n 64 above, 4.

68 See D Cornell Philosophy of the Limit (1992). See Woolman 'Book review: Moral Images of Freedom by D Cornell' (2008) 125 South African Law Journal 452.

69 n 64 above, 6.

70 For a comprehensive discussion of law's (in)ability to transform society, see A Kok 'Is law able to transform society?' (2010) 127 South African Law Journal 59 - 83.

71 See C Woodard "Toward a "Super Liberal State": A review of "The Critical Legal Studies Movement” by Roberto Unger' The New York Times 23 November 198627. See RM Unger 'The Critical Legal Studies movement' (1983) 96 Harvard Law Review 561-675; Fitzpatrick \& Hunt (eds) Critical Legal Studies (1987); M Tushnet 'Critical legal studies: A political history' (1991) 100 Yale Law Journal 1515-1544; and MG Kelman A guide to critical legal studies (1987). 
the legislature?) is often confronted with two contrasting options and considerations (encompassing clashing norms and principles). The final choice made by the judge is then closely tethered to her social, political, and ideological predispositions and values and not objectivity and neutrality. Duncan Kennedy explains: ${ }^{72}$

First, each argument is applied, in almost identical form, to hundreds or thousands of fact situations. When the shoe fits, it is obviously not because it was designed for the wearer. Second for each pro argument there is a con twin ... Although each argument has an absolutist, imperialist ring to it, we find that we are unable to distinguish particular fact situations in which one side is more plausible than the other. The difficulty, the mystery is that there are no available metaprinciples to explain just what it is about these particular situations that make them ripe for resolution. And there are many, many cases in which confidence in intuition turn out to be misplaced ... The ultimate goal is to break down the sense that legal argument is autonomous from moral, economic and political discourse in general.

The 'fundamental contradiction' thesis shows the inherent tension in law and society between individualism and altruism (that neither can offer a comprehensive vision of social and political life) and between form and substance. It also highlights some of the limitations that bedevil contemporary (or modern) legal thought. CLS scholars have forced legal academics and practitioners to accept the 'fundamental contradiction' thesis and to

... grapple with the complex links between law and structural constraints imposed on it by contingent dynamics in the state, economy, and culture - links often concealed by liberal visions legal formalism, legal positivism and even much of legal realism. ${ }^{73}$

So to where do we turn for a politics and ethics of refusal, critique and a risking law in the face of a conservative legal culture, a law that is far too blunt and too limited to achieve the goals of the Constitution and academics who refuse to accept or engage with theses like indeterminacy and fundamental contradiction? As earlier noted, refusal is a concept that focuses simultaneously on limits and on possibilities. We could then hope only to recall the aporetic moments of the Constitution and the utopian ideal embedded in it which will always be deferred, always be in a state of 'not-yetness' and always remain caught in its own limits, its own impossibilities. Douzinas is indeed correct to say that 'the end of human rights comes when they lose their utopian end ...' ${ }^{74}$ Douzinas notes: ${ }^{75}$

72 D Kennedy 'Form and substance in private law adjudication' (1979) 92 Harvard Law Review 1685 - 1778.

C West 'CLS and a liberal critic' (1988) 97 Yale Law Journal 757.

n 34 above, 380.

C Douzinas ‘Human rights and postmodern utopia’ (2000) 11 Law \& Critique 200 239. 
While like all utopians its realisation is always deferred, turning human rights from governmental triumphalism and diplomatic somnambulism into utopian hope would be the greatest contribution of our political culture to the new millennium.

By using narratives, stories, and allegories, the utopian imagination projects a future society and keeps it in abeyance, held together only by hope and uncertainty. This is a better response to a pessimistic, defeatist account of law's ability to restore, repair and reconcile and of the possibilities for meaningful change in the lives of people who remain marginalised by the structural inequalities and oppressive realities that haunt their gender, race, ethnicity and class. Refusal thus revives utopian thinking and upholds the transformative ideals of the constitution and human rights discourse while also being vigilant of the pervasive formalism dominating analytic jurisprudence.

Utopian thinking is open to multiple versions and meanings of reality. For that reason, it is an approach that resists the imposition of one definite, irrefutable version and expression of reality and rejects the notion of one "central truth. ${ }^{, 76}$ Cornell adds: 77

Utopianism has always been tied to the imagination, to visions of what is truly new. A new world in which we could share life's glories would be one radically different ... At last it is up to us to turn yesterdays' utopia.

\section{Doing refusal - refusal as/and the performative}

The notion of refusal could be well served by a brief recollection of Judith Butler's well-known idea of 'gender as performative."78 In short, Butler's point is that when women (as a special example) act and speak in a certain gendered way, they are not merely reporting on or performing something that is already fixed and immutable, they are in fact, actively constituting it, replicating it, and reinforcing it in the world. By behaving as if each sex has specific 'natures' and 'characteristics', the social fiction that these natures actually exist is actualised and reproduced. These social norms or power structures are never isolated or given - they exist by virtue of our affirming acts. Butler shows us that by continuously citing and conforming to the conventions and ideologies in the social world around us, we not only

$\mathrm{K}$ van Marle 'In support of a revival of utopian thinking, the imaginary domain and ethical interpretation' (2002) Journal of South African Law 501.

77 Cornell At the heart of freedom: feminism, sex and equality (1998) 186.

78 See J Butler Gender trouble: feminism and the subversion of identity (1989) and the follow up, Butler Bodies that matter: on the discursive limits of 'sex' (1993). 
enact that reality, we create it. We make social constructions like gender (and race) seem natural and necessary. ${ }^{79}$

Conversely, and this is where refusal comes in, by carrying out these behaviours, attitudes and gendered performances in a somewhat different manner, through parody and subversion, we can perhaps unmake them and in the process, redefine the norms, rules, narratives and meanings that control our lives. The wider notion of refusal as an act discloses possibilities for problematising dominant assumptions, hegemonic power structures and stereotypical roles ascribed to and forced upon, among others, women, black people and homosexuals on a larger scale. With this Butlerian insight, refusal could be connected to Kristeva's notion of 'revolt'. Kristeva finds that the term 'revolt' suggests political action and human agency because of its 'etymological association with return, patience, distance, repetition, elaboration.' 80 'Revolt is not simply about rejection and destruction; it is also about starting over' - it 'foregrounds an element of renewal and regeneration. ${ }^{81}$ Kristeva regards (the liberty to) revolt to be fundamental. For her, neither a life of thinking, nor a life of sociality, is possible without it. She adds that she is referring to " "life" here, and not just maintenance, repetition, management.'82

A succinct definition of the hegemonic order that the notion of refusal is set up to oppose and displace - to revolt against - is provided by Jean Comaroff and John Comaroff: ${ }^{83}$

[T]hat order of signs and practices, relations and distinctions, images and epistemologies - drawn from a historically cultural field - that come to be taken for granted as the natural and received shape of the world ... This why its power has so often been seen to lie in what it silences, what it prevent people from thinking and saying, what it puts beyond the limit of the rational.

Davis and Le Roux introduce the concept of 'lawfare' in their discussion on the use and abuse of law. Relying on the Comaroffs, ${ }^{84}$ Davis and Le Roux observe that as law becomes the primary instrument for structuring society, the targets of state power (i.e. citizens) invoke human rights to defend their freedom, privacy and personal sovereignty against attempts to use the law as a form of social control. To be clear, citizens thus refuse attempts by the state to emboss its authority and control over them through the medium of

Butler 'Performative acts and gender constitution: An essay in phenomenology and feminist theory' in S Case (ed) Performing feminisms: feminist critical theory and theatre (1990) $270-272$.

J Kristeva Revolt, she said (2002) 123.

As above.

n 80 above, 12 .

$\mathrm{J}$ Comaroff \& $\mathrm{j}$ Comaroff Of revelation and revolution: christianity, colonialism and consciousness in South AfricaVol 1 (1991) 23.

$\mathrm{J}$ Comaroff \& J Comaroff (eds) Law and disorder in the postcolony (2006) 26-27. 
law. ${ }^{85}$ The concept of 'lawfare' can be described as 'juridicalisation of politics' or the 'politicisation of the courts' - when citizens and communities take their struggles to the courts. ${ }^{86}$

Courts in some very tentative way could serve as the stage and battleground for refusal where the rights of people with HIV/AIDS to antiretroviral treatment can be claimed, ${ }^{87}$ where homosexuals can fight for recognition and dignity ${ }^{88}$ and where mourning families can refuse to accept that the TRC granted amnesty to the killers of their loved ones. ${ }^{89}$ The concern in this section is with practical, reformoriented and activist projects grounded in an ethics of refusal. It is also concerned with those subversive and parodic acts of resistance that so subtly challenge the established order. It is trite that the most obvious act of refusal and resistance is civil protest, especially that conducted by social movements. As Ashwin Desai and Richard Pithouse note, 'revolts have ebbed and flowed in poor communities all over the country since 1996.' 90 Patrick Bond points out that 'the pace of social protests intensified dramatically during the mid-2000s soaring from 5,813 recorded protests in 2004-05 to more than 10,000/ year'. ${ }^{91}$ Tshepo Madlingozi connects the notion of refusal with Michael Neocosmos' conception of an active citizenship that 'refuses the technicisation of politics as well as the passivity engendered by ... an over-reliance on human rights. ${ }^{\prime 92}$

Madlingozi raises the point that many community organisations, including Abahlali base Mjondolo, the Treatment Action Campaign, and the Anti-Privatisation Forum have enacted their own politics of refusal through activism against the onslaught of privatisation, poverty, neo-liberal policies like GEAR as well as the slow realisation

$P$ Bond 'Rejoinder: collaborations, co-optation \& contestation in praxis-based knowledge production' (2008) 35 Review of African Political Economy 272. Following on earlier critiques, the struggle theory would not have facilitated the civil society protests and labour strikes because the struggle theory speaks to blatantly unstable and despotic states. Refusal on the other hand is specifically about acting and revolting against pervasive and deceptive attempts to circumvent human agency through law and constitutional patriotism irrespective of whether there are strong governance mechanisms and human rights instruments.

9

T Madlingozi 'HayiBo! refusing the plan - acting, thinking and revolting by postapartheid social movements and community organisations' in K van Marle (ed) Refusal, transition and post-apartheid law (2009) 82. 
of socio-economic rights. For Madlingozi, it is 'bottom-up' types of politics exemplified by these movements that are at the heart of refusal and revolt in the post-apartheid State.

The presence of social movements, civil society and community organisations adds to the view shared by some that Van Marle could have overstated her argument that the enthusiastic embrace of human rights law has lead to a complacent society in which 'political action, thought, eternal questioning and contestation are absent and replaced by an understanding of freedom as mere commercial/ economic freedom and of thought as calculated and instrumental ... ${ }^{93}$ Madlingozi calls for critical theorists to refuse the bureaucratisation of political action and the 'robotisation' of life and thought' and for refusal to be linked with activism. ${ }^{94}$ The notion of refusal thus needs to be widened to accommodate acts of refusal such as COSATU-led labour strikes, civil society marches for women's rights and service delivery and the work of post-apartheid social movements in order to articulate South African society more fully and accurately.

It is useful to recall Patrick Hannafin and his evocation of Maurice Blanchot's act of refusal. Blanchot was the main drafter of the Declaration of the Right to Insubordination in the Algerian War (Manifesto of the 121). ${ }^{95}$ Hannafin notes how Blanchot called for the 'absolute right to refuse to accept' the state's contention that the French colonial war in Algeria was executed in the interests of the people. In the process of drafting the Manifesto, Blanchot also had many concerns namely, 'the contest between law and its other'; 'the play between power and transgression' and the ethics of 'responsibility' 96 for other human beings. The declaration in effect was a refusal of the way in which 'legal language taxonomises the subject' 97 and thus established the right to refuse to take up arms and go to war against the Algerian people - a right which was not granted by law or justified through any moral code (in short, a right to defy the state). The State then initiated criminal proceedings against all the drafters of the Manifesto. Blanchot enacted his own ethic of refusal when he objected to the magistrate summarising his statement instead of allowing him to give a testimony. Blanchot's act(s) of refusal exposes the 'fragility', rigidity and 'mortality' of law

93 n 2 above, 196.

94 n 92 above, 89.

$95 \mathrm{n} 49$ above, 3. This is again indicative of the interplay between the claims of the struggle theory and the objects of refusal. The Declaration was effectively also a codification of the right to self-help (that is, the right to ultimate refusal - to refuse to abide by state laws in favour of justice, freedom and dignity and to refuse 'to submit to law' (through state power), 'to be insubordinate').

As above.

97 As above. 
and is also indicative of the need for action, thinking and revolt to be central to the notion of refusal and to post-apartheid legal theory: ${ }^{98}$

I signed this text ... as an apolitical writer who felt moved to express and opinion about problems that concern him essentially ... One of the main purposes of the Declaration is to bring about the particular responsibility of intellectuals: when the democratic order is corrupted or decays, it falls to them, independent of any purely political allegiance, to say in simple terms what seems to them just.

Indeed the act of refusal is subversive and transgressive, disruptive and interruptive, idealistic and irreverent - located in a liminal, inbetween space, a precarious and volatile temporality. Drawing from the world of art, let us recall one more example of refusal in the aesthetic portrayal of Justitia, the goddess of justice.

According to Martin Jay, Justitia was originally a seeing maiden until the end of the 15th century, when a blindfold covered her eyes. ${ }^{99}$ He explains how, what was actually a satirical addition, had, by the mid-16th century, become a deeply entrenched narrative of the official legal discourse. This suspect new image of 'blind justice' corresponded with other changes that occurred in the legal sphere: the removal of artworks and illustrations from courts and law books, and judges wearing dull black and white robes - essentially killing the spirit of law. These changes in legal culture, connected to the spread of Enlightenment thinking and the rise of the secular, urban bourgeois culture, can be attributed to the rapid rise of science, logic, rationality and abstraction as the only acceptable modes of thought and reasoning in Western modernity.

Jay reads the blindfold of Justitia as an effort to mask the intuition and perceptiveness associated with the feminine, cunningly to ensure that the dominant hegemony was also extended into law. These changes all sought to eliminate any concrete or bodily attachments from law, which, for the purposes of legal theory, symbolise what Jay calls 'the modern cult of the abstract and determinant norm of legal formalism ...' 100 The new paradigm of impartial, objective and strict justice led to a bombardment of statues and fountains depicting a blindfolded Justitia and subsequently reified this image as law, resulting in the rejection of all visualisations, values, voices and visions that differ from this 'certified' idea of law.

Just as refusal calls for us to displace the fundamentalist belief in scientific foundations and (common law) classifications as the only

98 n 49 above, 7. See M Blanchot 'The right to insubordination' in M Holland (ed) The Blanchot reader (1995) 196.

99 M Jay 'Must justice be blind? The challenge of images to the law' in C Douzinas and L Nead (eds) Law and the image: the authority of art and the aesthetics of 100 law (1999) 19 -35.

n 99 above, $23-24$. 
way of doing law, so should the traditional image of a blind (unseeing and uncaring) Justitia be challenged and refused. As Van Marle suggests, we should focus on the energy of resistance provided by the black, naked, seeing Justitia drawn by artist Braam Kruger that appeared on the posters from the University of Pretoria Centre for Human Rights promoting the first human rights conference in the late eighties - a time when apartheid was at its height. ${ }^{101}$

The first act of refusal was the persistence with which the Centre for Human Rights itself was formed against the backdrop of a historically white Afrikaner University and a Faculty of Law that was trapped by the dogmas of judicial avoidance, positivism and the common law - with some colleagues at the time even suggesting that human rights was not a 'legal discipline' and hinted of 'politics'. The second act of refusal was daring to host a conference on human rights in a society where the law confirmed the claim that only white people were human beings and black people were sub-humans subjected to the worst forms of subjugation, brutality and oppression.

The third and most subversive act of refusal was indeed the image of a black woman being projected as the goddess of justice in light of the position of blacks and women at the time. Not only was the blindfold removed to embrace a conception of justice based on care and paying attention to the material conditions, needs, experiences, and fears of human beings. It also depicted a black woman - a victim of both white supremacy and patriarchy - as the ideal representation of justice. This image remains a suspensive utopian ideal keeping alive the hope that, one day, black women will be intrinsically worthy of respect and free of domination and misery, equal with whites and men.

\section{Conclusion}

To bring to light the singular character of this refusal is one of the theoretical tasks of the new political thinking. This theoretical undertaking obviously does not entail drawing up a programme or a platform, but rather, independent of any programmatic project, indeed of any project, maintaining a refusal that is an affirmation, bringing out or maintaining an affirmation that does not come to any arrangements, but rather undoes arrangements, including its own, since it is in relation with dis-arrangments or disarray or else the non-structural. ${ }^{102}$

Let us return to three related moments in this article: 'refusal as critique' is a counter-hegemonic disruption to the business-as-usual

$101 \mathrm{~K}$ van Marle 'Meeting the world halfway - the limits of legal transformation' (2004) 16 Florida Journal of International Law 662. The artwork is entitled 'Anna Mongale as Justitia' (1989).

102 M Blanchot 'Affirmer le rupture' in M Holland (ed) The Blanchot reader (1995) $200-201$. 
approaches to law and politics. I have argued that refusal as an ethical notion can challenge judgements concerning people's wellbeing to be more generous (by being attentive to complexity, particularity and context) and force lawyers and legal scholars to take up the challenge of transformative constitutionalism. The ethics of refusal not only says 'no', it asks 'why' and 'why not' but never says 'never'.

In 'refusal as limit and possibility' I suggested that by engaging with the limits of law, refusal opens law to new possibilities and unpredictable directions. Refusal thus calls for keeping the utopian promise of the Constitution alive. 'Refusal as performative' recalls our complicity, responsibility and agency. As subjects within a more totalising system of power and domination, we must - like postapartheid social movements, the black Justitia, and Blanchot - enact refusals and resistance(s) intended to displace the hegemonic orders of patriarchy, racism, neo-liberalism, capitalism, and repression. Refusal in its performative mode is an active and audacious politics connected to the words of Bartleby, 'I would prefer not to'103 and does not merely imply bystanding, compromise or standing back.

Throughout this essay I have attempted to demonstrate that the act and ethic of refusal is a decidedly unorthodox approach to conventional law and human rights. Refusal urges a critical distance from the mainstream and underscores the necessity of a critical and thoughtful engagement with the complexities and vagaries of law, politics and society within the context of shifting South African realities.

That refusal cannot be situated, categorised or systematised under any specific normative theory of or approach to law is one of its most defining features and indeed, what makes it truly path-breaking. By asking the questions that should vex any serious legal scholar: What is law? What exactly is so special about law? What can and can't law do? And, following Aristotle, what role can law play in creation of the good society? Van Marle pushes us to embrace refusal as a mode of critical thought in the face of thoughtless, instrumental and calculated accounts of law, virtue, justice, community and ultimately, life.

Specifically in a post-apartheid context, it is crucial that we embrace alternative approaches to law and human rights. The significance of refusal is that it marks a decisive objection to the business-as-usual approach adopted by lawyers, judges and academics that continue to remain prevalent, even after the major constitutional changes that occurred in our country since the early 
1990s. The problem with this approach is that it entrenches conservative and traditional practices in the South African legal culture and excludes all voices that are different from this comfortableness. The continued belief in scientific classifications and old-school legal thinking is both counter-productive and inefficient. If we are indeed to cultivate an active politics and democratic culture, we cannot uncritically genuflect to the promises of the Constitution in the form of formal law and institutionalised human rights. The politics and ethics of refusal turns away from 'traditional ways of thinking and doing law' and openly accepts the 'unexpectedness that breaks with the formality and predictability of law.'

I would like to conclude with a final note of candour: Of course, the notion of refusal and much of the scholarship that shares its ideals and works from similar paradigms (such as postmodernism, CLS, aesthetics, law and literature) have constantly come under the hackneyed criticism that they are too 'idealistic'; 'irrelevant'; 'obscure' and 'abstract.' These writings are regularly accused of over-theorising and over-philosophising at the expense of issues and efforts that fall within the ambit of 'real work' and 'real law' often because they engage with art and literature rather than, or more than, case law and legislation. In other words, they opt for critique rather than technical analysis. To my mind, the pressures and demands for all 'legal' research to prove practical relevance and immediate success operate from the static reading of law as neutral, apolitical and fixed. Questions concerning the politics of law, the limits of law, the possibilities of law and their connection to everyday life and the nuanced differences and complexities of living cannot be separated from research, teaching and practice in law, from the 'real work' and from 'real law'. ${ }^{104}$

The artificial dichotomy between theory and practice and between philosophy and reality negates three critical points. First, the loaded, contingent and normative nature of 'law' itself: that it is not set in stone but can be changed, challenged and re-imagined. Secondly, that philosophical reflections and theoretical multidisciplinary research often serve as the groundwork for litigation and activism, but the two are still qualitatively different and neither claims the role of the other. Thirdly, and most importantly, academic thinking and research within a university should not merely be

104 The debates arising out of these criticisms are explored in various writings - most notably in $\mathrm{n} 13$ above, 297; 'Jurisprudence, friendship and the university as heterogenous public space' (2010) 127 South African Law Journal 645; W Le Roux \& K van Marle 'Postmodernism(s) and the law' in C Roederer \& D Moellendorf (eds) Jurisprudence (2004) 354; D Davis 'Duncan Kennedy's A Critique of Adjudication: a challenge to the "business as usual" approach of South African lawyers' (2000) 117 South African Law Journal 697; J van der Walt 'The quest for the impossible, the beginning of politics: a reply to Dennis Davis' (2001) 118 South African Law Journal 463. 
functionally applied as an instrument but also as a constant engagement with complexity, academically multiple possibilities and with a 'politics of the future.' The charge that such work is produced by 'ivory-tower academics' in their 'air-conditioned offices' is, contrary to its claims, part of efforts at gate-keeping and regulating legal thinking. This limits possible theories and excludes critical voices rather than expanding and exploring the ways in which the law can indeed be an instrument and source of social change, justice and ethics. For that reason we should be sceptical of instrumental reliance on rational knowledge and significantly break away from traditional and unreflective approaches and perspectives as they could lead to misdirection in our efforts to positively transform the human condition. Life demands more. People deserve better.

I just do things

The mob has plans. The cops have plans. Gordon's got plans

You know, they are schemers

Schemers trying to control their little worlds

I am not a schemer

I try to show the schemers how pathetic their attempts to control things really are ... 


\title{
DISCUSSION ON CHARACTERISATION* IN SOUTH AFRICAN PRIVATE INTERNATIONAL LAW*
}

\author{
by Justin Leach**
}

\section{Introduction}

To inform those unfamiliar to the subject, private international law is simply that branch of a country's domestic law, which regulates the relationship between private individuals when foreign legal rules are in some way concerned. This branch generally has three subbranches: Jurisdiction (choice of court), choice of law and recognition of foreign judgments. ${ }^{1}$ The discipline of characterisation forms part of the choice of law sub-branch and is explained further below.

This article discusses the problem of a 'gap' arising from the phenomenon of characterisation in South African private international law, by considering the current case law authorities on the matter as well as the criticisms (and suggested solutions) of legal academics. A general discussion of characterisation, with some alternative suggestions for dealing with the problem, is also mooted for consideration in a bid to air ideas. No short work could do justice to the problem visited here. This work seeks to show that the obsession with characterisation in the choice of law arena is perhaps ill founded and should perhaps be simplified in favour of a 'most natural results' approach.

Few problems have vexed me quite like the questions I have sought to answer hereunder, with each proposed solution came a myriad of additional problems and the solutions appear ever more convoluted. As I waded through the mire of academic opinion and liberally applied judicial discretion I began to wonder if the individuals seeking the solution to their problem were not lost in the debate, if the overly complex issue of characterisation was not simply a petulant child of the academic mind and should be done away with in favour of a simpler approach.

* Synonymous, in this context, with classification, though characterisation is the term used throughout this text.

** This paper was originally an assignment submitted in partial fulfilment of the elective course Private International Law 410 lectured by Professor TJ Scott and has been adapted for this publication. I wish to thank Professor Scott for his encouragement and endearing manner of teaching.

*** BA (UP), Final year LLB Student, University of Pretoria.

1 CF Forsyth Private international law: The modern Roman-Dutch law including the jurisdiction of the High Courts (2003) 4 - 5. 


\section{A brief description of characterisation}

The problem of characterisation exists in the reality that different legal systems may view the same set of facts as resulting in a legal question or problem which is governed by different normative rule sets, for example: a contractual question under one legal system might well be a matrimonial property question under another system. ${ }^{2}$ This in turn has sparked a debate over which legal system should take precedence, causing characterisation to become a confused and disputed concept. ${ }^{3}$ In essence it would appear that this concerns the determination of the legal category into which a legal problem, arising from the specific facts in issue, may be applied. Thus, the object of the characterisation exercise is to determine the set of norms that govern this particular question. In the case of private international law this means that characterisation determines which 'conflicts rule' would apply to resolve the dispute.

Forsyth asserts that legal rules or norms are classified. ${ }^{4}$ Booysen J accepted this in Laconian Maritime Enterprises Ltd $v$ Agromar Lineas Ltd (Laconian case). ${ }^{5}$ This approach to classification may however yield unsatisfactory results, such as the situation experienced in the Laconian case. In this case a number of rules were uncovered before the legal question was properly ascertained and in effect a solution was then chosen and justified accordingly. ${ }^{6}$ In reinforcing his point that legal rules are characterised, Forsyth states that a litigant asserts that a legal rule is applicable whilst the other litigant rejects this, hence the rule must be characterised in order to determine which legal rule set applies to the matter. ${ }^{7}$ The problem with this statement is that a factual situation gives rise to legal consequences which exhibit an inherent legal character. Hence, in a domestic legal setup,

2 Forsyth (n 2 above) $68-69$.

3 Forsyth (n 2 above) 68 describes characterisation as the first step in dealing with a multilateral conflicts rule, ie ascertaining the category of the problem in question which may then be combined with a factual connecting factor to determine the applicable legal system. This in itself is not confusing; the problem comes arises when one is faced with the lex causae $(73-74)$ approach to characterisation which uses the (as yet undetermined) applicable legal system to classify the legal problem in order to determine the applicable legal system, resulting the problem of circular logic. It must also be said in this regard that the problem cannot be escaped through recourse to characterisation purely according to the lex fori as this will yield unsatisfactory and unjust results; see in this regard the English case Ogden $v$ Ogden 1908 P 46.

4 CF Forsyth 'Enforcement of arbitral awards, choice of law in contract, characterisation and a new attitude to private international law' (1987) 93 South African Law Journal 4; see para 4 below for discussion on the general approach to characterisation.

$5 \quad$ Laconian Maritime Enterprises Ltd v Agromar Lineas Ltd 19863 SA 509 (D) (Laconian case).

6 See further discussion below regarding the residual lex fori approach adopted by the court.

7 n 2 above, 71. 
when a dispute arises over which rules apply the factual situation is scrutinised to glean the legal nature of the problem. It is crucial to note that the legal nature or character of the problem is not determined ex post facto; the enquiry is to determine what the already existent character of the problem is. Why is the reverse true in the private international law realm? The possible applicable rules are considered characterised and then chosen to suit the situation; in effect the rule chooses the situation rather than the situation choosing the rule, as is normal and logical. Regardless, courts favour the characterisation of legal rules, although this situation should perhaps be questioned and revisited with the same logic applied to ordinary domestic legal disputes. ${ }^{8}$

\section{Characterisation and the gap}

In the Laconian case ${ }^{9}$ the court per Booysen $\mathrm{J}$ was called on to enforce an arbitration award that was granted in terms of and governed by English law. A large part of the judgment concerned the question of prescription. It was found that the applicable English prescription rule was procedural in nature, which in terms of South African conflicts rules requires that the lex fori be applied. On the other hand, the South African prescription rule was found to be substantive in nature, which in terms of South African conflicts rules requires the application of the lex causae. ${ }^{10}$ Hence a gap was formed, in terms of the choice of law rules, neither legal system was applicable. Booysen $\mathrm{J}$ resolved this by asserting that characterisation is an interpretative process and thus procedural. This logic led him to the adoption of a residual lex fori approach. ${ }^{11}$ The same approach was followed by the court a quo in Society of Lloyd's $v$ Price, Society of Lloyd's $v$ Lee (Price case). ${ }^{12}$ Bennett and Kopke ${ }^{13}$ offer a solid criticism in this regard in stating that: ${ }^{14}$ Society of Lloyds v Romahn 20064 SA 23 (C).

9 n 5 above.

To elucidate the reason for this situation: once the lex causae has been determined then it is generally accepted court practice that only the applicable substantive rules of said lex causae may be applied, and that procedural rules are governed by the lex fori; various reasons for these rules exist, see in this regard: E Khan 'Conflict of laws' (1986) 12 Annual survey of South African law 537 - 538; Forsyth (n 2 above) 75.

$11 \mathrm{n} 5$ above, 524. This situation should be avoided as the court does not properly evaluate which rules should be applied but rather in an almost irrational manner retreats into its comfort zone for convenience sake. This is discussed further by TW Bennett \& K Kopke 'Society of Lloyd's v Price: Characterisation and "gap" in the conflict of laws' (2009) 125 The South African Law Journal 65.

12 n 9 above.

13 Bennett \& Kopke (n 12 above) 65.

14 As above. 
Allowing the forum to stipulate a category without paying any regard to other potentially applicable laws, however, may obviously distort the choice-of-law process, not to mention suggest judicial chauvinism and even encourage forum-shopping.

The supreme court of appeal in the Price case rejected the court $a$ quo's usage of the residual lex fori approach to resolve the 'gap' problem. The appeal court stated that an informed policy drivenapproach should be adopted to ascertain which of the competing legal systems has 'the closest and the most real connection with the legal dispute before [the court] ...' ${ }^{15}$ This view appears to be correct, as the court seeks to ascertain the most natural legal system to deal with the legal problem. The court then considered numerous factors that may indicate such a 'close and real connection' and in this instance most of the factors considered arose out of the contract in issue. It is submitted that there is no reason why this same logic could not be applied to matters beyond the scope of contract law. Any number of facts in any situation may be indicative of a legal system, which should most naturally govern a particular issue. It would seem that the court in Society of Lloyd's $v$ Romahn ${ }^{16}$ (decided shortly before the Price case) also adopted the approach of seeking the 'proper law'.17 In this decision the via media ${ }^{18}$ approach was followed. The operation of which is as follows: the court must consider the question raised by the factual situation by considering the rules of the two potentially applicable legal systems in relation to the facts to determine whether, on the facts, a question is in fact raised by either legal system. Once this has been done, the court has a legal question and may then match this question to the question required by the potentially applicable conflict rule. ${ }^{19}$

The problem with this approach is that the court must still balance the contentions of the two legal systems. Thus, the via media approach does not provide an answer, but merely a guideline to the enquiry, the quality of which is dependent on how the court informs itself and evaluates the foreign legal question. This may lead to 'result shopping' as the court exercises a wide discretion on the basis of reasonableness and equity rather than the most correct/naturally applicable system. In other words: the court selects a result and sets about justifying the rule rather than the seeking the governing rule to determine the result.

15 Price (n 9 above) para 25.

16 n 9 above.

17 Price (n 9 above) para 82.

18 The approach posited by Falconbridge in his article 'Conflict rule and characterisation of question' (1952) 30 Canadian Bar Review 103. This article could, unfortunately, not be obtained at the time of drafting. It is, however, discussed at length in C Turpin's 'Characterisation and policy in the conflict of laws' (1959) Acta Juridica 222.

19 Turpin (n 19 above) 223. 
The problem with the Price decision is that the court failed to provide a sufficient explanation of how it decided on the factors to be used in determining the legal question and thus the applicable legal system. The court effectively failed to give substance to its 'most closely connected' approach. This allowed the via media approach, which the court used in conjunction to upstage a potentially significant development. ${ }^{20}$ The problem with the via media approach may be seen in Laurens NO $v$ Von Höhne ${ }^{21}$ where the court used via media as a justification for tainting the decidedly applicable lex causae with the principles of the lex fori, in effect creating a hybridised set of rules tailored to the specific situation under the guise of policy considerations. ${ }^{22}$ The court itself, in support of the via media methodology states: ${ }^{23}$

If no regard is had to foreign law, what is likely to ensue is that the nearest analogue of the lex fori is laid on a Procrustean bed and subjected to a process of chopping off or stretching.

In the same manner, however, policy considerations become nothing more than a theoretical Theseus ${ }^{24}$ laying the lex causae on its own procrustean bed and shaping it to suit the lex fori. This showed the via media applied by our courts to be nothing more than Latin terminology for unbridled judicial discretion.

\subsection{Inherent character}

Once the most 'closely connected' or 'most natural' legal system (Lex causae) is determined using appropriate factual considerations, the next step is to find the specific foreign legal rule governing the situation. Seen from this perspective characterisation should not be a problem, as legal rules bear their own inherent character ascribed to them by their own legal system. Thus, it is proposed that the starting point in a choice of law situation is not characterisation but rather the mere averment that a foreign legal rule applies. By this it is meant that a rule's character is not some separate aspect required for the rule's existence, but instead is an inextricable part of the rule and can only be properly viewed and applied by taking cognisance of the context of its own legal system, the purpose ${ }^{25}$ specifically for which it exists within the society it originally sought to govern. ${ }^{26}$ In this way the question of law is dealt with in the most natural way, as if it were

C Schulze 'Conflict of laws: foreign judgments' (2006) 32 Annual Survey of South African Law 837839.

Laurens NO v Von Höhne 19932 SA 104 (W) 117-119.

The cornerstone of the via media approach.

n 22 above, 118; referring to Forsyth (n 5 above).

Greek mythology: Theseus ended Procrustes' terror spree by killing him in his own manner, by laying him on his own steel bed and 'fitting' him to it.

Price (n 9 above) para 27-28.

Schulze (n 21 above) 839. 
raised before a court of the land whose law is determined to apply to the matter. The court (a court of the lex causae) dealing with the matter should not be overly swayed by notions of achieving the most equitable result within its own context but should rather seek the result most like that which would naturally have ensued from the situation; the result which would have ensued had the matter been brought before the normal (foreign) court, which normally would have had jurisdiction. I respectfully submit that this is the result that the appeal court sought to achieve in dealing with the Price case, although the court differed in its reasoning. ${ }^{27}$

\subsection{Prescription as a unique problem area}

To allow prescription to vary depending on whether or not the prescription rule is substantive or procedural in terms of the lex causae $^{28}$ is artificial and may result in forum shopping ${ }^{29}$ among other problems, a fact which was quite correctly noted by the court in the Price case. In a bold and commendable manner the court stated that the specific nature of the prescription in question was irrelevant as the law with the 'closest and most real' connection had been ascertained, and as such prescription as it was pronounced under that (proper) law should be applied. ${ }^{30}$ Unfortunately in this same vein the court digressed into a discussion of the inconsistency of the lex causae in respect of prescription rules, seeing this as cause to disregard the distinction between substantive and procedural prescription; effectively leaving the question of prescription in the same precarious position it was for cases where the lex causae is found to treat prescription in a consistent manner. As Neels ${ }^{31}$ suggests, perhaps it would be more appropriate to create a general exception to the rule that procedural rules are governed by the lex fori. Such an exception would with cunning simplicity state that issues of prescription are always dealt with in terms of the lex causae, thus resulting in the legal effect most naturally ensuing from the factual situation, since the resultant effect of prescription on the particular situation then has

28 Price (n 9 above) para 25-28

Hence in a mechanical fashion one applies the lex fori rules regarding prescription when the lex causae characterises the specific prescription question as procedural, as was the situation visited in the Laconian case (n 5 above); it should be noted that the reverse is not necessarily true.

29 Example: a legal situation/claim may well have prescribed in terms of the lex causae but simply on the strength of the rule of prescription being procedural a party may approach a South African court because in terms of South African law the claim may still be possible; the reverse is also true as it would, clearly be artificial to disallow a claim which is valid and enforceable in terms of the lex causae but which is deemed not so merely because the dispute arises before a South African court.

30 n 9 above, para 28.

$31 \mathrm{JL}$ Neels 'Tweevoudige leemte: Bevryende verjaring en die internasionale privaatreg' (2007) 1 Tydskrif vir die Suid-Afrikaanse Reg 178, as cited and discussed in Bennett \& Kopke (n 8 above) 69. 
the legal effect it would have had if the scenario had come before a court of the lex causae. Effectively this negates the possibility of forum shopping on the basis of prescription. Further to this point it is apparent that prescription is the most common legal rule-type giving rise to a 'gap' through characterisation, therefore such an exception to the existing rule could well be founded to ensure consistent results without the need for ad hoc rules to be created. In this regard the approach suggested by Neels ${ }^{32}$ also, and rightly so, does away with the illogic of separating prescription from the main issue based purely on the character of the specific prescription rule within the lex causae. ${ }^{33}$

\section{Proposals for resolving the characterisation issue}

The discussion below bears little authority in law and is intended as an area for consideration of ideas beyond the scope of clinical academic debate, where the existing approach to ascertaining the applicable legal system in conflicts cases may be questioned on a fundamental level.

\subsection{Determining the applicable legal system without characterisation}

The most apparent problem from the discussion above is how exactly the 'most naturally' applicable legal system is to be determined. If characterisation is to be avoided then the 'most naturally' applicable legal system must be found with sound reasoning and particularity, and dealt with question by question according to the determination. The fact that a matter appears before a court of the lex fori with the suggestion that a foreign legal rule applies shows that a factual situation with legal consequences arose under one legal system and that the situation has now, in some way, migrated to be decided by the court of another legal system. Such a situation may very quickly and permanently be relocated physically or figuratively, to operate under another legal system as in the case of Frankel's Estate $v$ The Master. ${ }^{34}$ In such an instance a simple conflicts rule such as 'the proprietary consequences of a marriage are determined by the law of

Khan (n 11 above) 542, also appears to support this view, albeit indirectly when

34 he states that the lex causae of a claim should govern all aspects of the claim. Frankel's Estate $v$ The Master 19501 SA 220 (A); In which a man and women were married in Czechoslovakia in 1933, at the time of the marriage the husband was domiciled in Germany whilst the Wife was domiciled in Czechoslovakia. No antenuptial contract was concluded. Shortly after the marriage the coupled moved to South Africa where they intended to settle permanently; having so 
the husbands domicile at the time of entering the marriage' as applied in South Africa will only generate artificial results because there is no longer a 'real' link to the legal system under which the factual situation originated. In Frankel's case the newlywed couple's near immediate and permanent move from Germany to South Africa meant that for all intents and purposes their marriage subsisted as a South African marriage. The only connection to Germany for the purposes of the marriage was that it was the husband's domicile ${ }^{35}$ at its conclusion in 1933. Why should this fact govern the marriage in perpetuity? The husband was naturalised as a South African in 1938. It is therefore suggested that perhaps marriages and other legal relationships should also be capable of a form of 'naturalisation'. Essentially such a possibility would mean that the factual situation dictates the applicable legal system rather than the classification of the contended legal rule, thus classification becomes irrelevant to the determination of which legal system to apply as the facts and circumstances of the case present the naturally applicable system by way of indicative factors ${ }^{36}$ much like those considered when ascertaining the proper law applicable to contracts. Classification is thus relegated to its usual position of providing context for interpretation. ${ }^{37}$

A further argument in support of this position would be to query whether or not a couple may alter the proprietary consequences of their marriage by agreement. If this is possible, it begs the question why this change could not be effected by tacit means, such as moving to another country to live as husband and wife indefinitely. ${ }^{38}$

\subsubsection{Static and dynamic legal issues}

At present from a private international law perspective, legal rules are seen as static, which has led to the obsession with

settled they remained, the husband was naturalised as a citizen of the British Empire in 1938. He subsequently died in 1948, the wife then sought a declaratory order stating that the marriage was in community of property on the basis that the proprietary consequences of a marriage be determined by the law of the place of the intended matrimonial home; the master opposed this invoking the accepted rule that the proprietary consequences of a marriage are determined by the law of the husbands domicile at the time of entering the marriage; the master's contention was upheld.

35 The problem is not that it is the husband's domicile, the same issue would exist if it were the wife's domicile or the lex loci celebrationis, the problem here is that the rule is so final, causing a single moment in time to govern indefinitely.

36 Khan (n 11 above) 543.

37 Although the forum should apply its own normal interpretation rules taking cognisance of the foreign context because it would be unreasonable and infeasible to expect courts to import interpretation rules and general procedural rules; the exception for prescription as posited above should still stand.

38 Of course such tacit means would need to be significant; a legally acceptable threshold for acceptable tacit expression of the desire to alter the proprietary consequences of a marriage would need to be developed. 
characterisation in order to ascertain rules to resolve disputes. The solution visited in 4.1 above proposes that some legal rules should be seen as dynamic, and dependent on the factual situation. ${ }^{39}$ In essence this view holds that factual situations give rise to certain legal consequences (legal facts), some of which are dependent on the factual situation, whilst others exist independent of such factual situations. Those that are dependent legal consequences may change as the situation changes, including the possibility of having the applicable legal system change with the situation. Whilst on the other hand, those consequences that are static exist in terms of the legal system under which they arose and cannot be changed. For example there should be a fixed rule when dealing with the validity of a marriage. It is determined at the time of the conclusion of the marriage by the legal system under which the event occurs and the legal factual result cannot change once it has occurred. ${ }^{40}$ The marriage is either valid or invalid as it is dependent on what happened factually at a specific point in time. Contrariwise, the proprietary consequences of a marriage exist in an ongoing factual situation which is factually not dependent on a particular moment in time except from the artificial and narrow perspective of unyielding conflicts rules. A husband and wife may organise their lives together as they see fit. Thus it makes little sense that the consequences of their decisions be governed by an arbitrary fact at an any point in time since in the meantime they will do what they like, regardless of the law.

The consequences of these organisational decisions are left to be determined by a court as and when a dispute arises based on the specific facts. A rule in this regard cannot be so flimsy as to change the legal system governing the proprietary consequences of a marriage every time the couple go on holiday. A simple threshold requirement would strengthen the rule and remedy any absurd results. Hence it should be possible for the legal system governing such consequences to change with the factual situation. This methodology is proposed as a starting point for an enquiry into the factual situation (giving rise to the legal question) in order to ascertain the applicable legal system without recourse to characterisation, with all its inherent problems.

\subsection{Inherent character of rules}

Lastly is bears mentioning that the character of a rule is a fact of the particular legal system. It is an automatic process inherent to each

39 Certainly not all legal rules should be seen in this light. However, there should be good reason why a rule should not change as situations change.

40 Except reconstituting the marriage with a new factual occurrence, but this would still be a different occurrence at a different time. 
and every legal system. Characterisation may take place at different times. If the logic of the static, alternatively the dynamic legal facts is followed, then it must be seen that static legal facts are characterised when they come into being and must retain their character in terms of the lex causae. In the case of dynamic rules, they may be re-characterised in the event that the applicable legal system is altered. Thus the forum considering these rules should query whether the rules are required to be characterised at the time of the legal proceedings, in which case this must be done in terms of the lex fori, or if the characterisation already exists, according to the lex causae.

\section{Concluding remarks}

Ascertaining the applicable legal system in a choice of law is important. It is submitted that it should be based on a factual inquiry to determine the legal issues in order to find the most natural and most closely connected legal system to govern the specific situation before the court. Uniformity of decision-making may well be achieved by the forum seeking to be as much like a court of the lex causae as is reasonably possible, provided the applicable legal system is properly ascertained. Courts must use sound reasoning to ascertain the rules governing the situation and must then adhere to precedent. Characterisation cannot be used as an excuse for equity shopping, nor should it be used as an excuse to uphold the lex fori arbitrarily. The Supreme Court of Appeal's decision in the Price case would seem to be moving in the direction of a 'natural results' approach. However, the basis for determining the applicable legal system should be revisited due to the convoluted nature of characterisation. 


\title{
TRANSBOUNDARY ENVIRONMENTAL POLLUTION: UNDERSTANDING THE INTRICACIES OF INTERNATIONAL LAW
}

\author{
by Kshitij Bansal*
}

\section{Introduction}

Man is endowed with reason and creative powers to increase and multiply his inheritance, yet up to now he have created nothing, only destroyed. The forests grow ever fewer; the rivers parch; the wild life is gone; the climate is ruined; and with every passing day the earth becomes uglier and poorer.

Anton Checkov ${ }^{1}$

The concept of protection, preservation and sustainable use of the environment and its components is not new to mankind. However, the last three decades have witnessed massive industrialisation in the quest for advancement. The sad part, however, is that all this has been done at the cost of environment. Scant regard has been paid to the need and importance of a development that is sustainable. Reckless cutting of trees at unprecedented rates has taken away the carbon sink from the ecosystems. This large scale deforestation, accompanied by a continued release of industrial waste into the atmosphere has led to a dramatic global climate change which has started showing visible symptoms like rise in the sea levels, prolonged droughts, and widespread heat waves. ${ }^{2}$ To worsen it further, there are additional problems like the depletion of the 'ozone layer', food security, flooding, desertification and many others.

Moreover, the latter part of the 20th century has also witnessed accidents that have caused unprecedented harm to the environment, which have reminded the world that environmental protection has to be an international responsibility. ${ }^{3}$ In 1984, methyl isocyanate gas leaked from a plant at a Union Carbide subsidiary in

Specialising in international laws and global governance at Rajiv Gandhi National University of Law, Punjab, India.

A Checkov The chamelion (1886) 124.

D Wirth 'Climate chaos and foreign policy' (1989) 74 Spring Foreign Policy 322.

Vienna Convention for the Protection of the Ozone Layer (Vienna Convention 1986). 
Bhopal, India and 2000 people were killed while 200000 injured in one of the worst industrial disasters in global history. ${ }^{4}$ In 1986, an explosion at the Chernobyl Nuclear Reactor in the Soviet Ukraine caused the first officially reported radiation deaths in a nuclear power plant accident and released radioactive material that drifted as far as the United States. ${ }^{5}$ Later in that year, fire hoses used to combat a Swiss warehouse blaze washed thirty tons of chemicals into the nearby Rhine River, in an event decried as one of Europe's most serious environmental catastrophes. The Bhopal accident, the Chernobyl fire and the Swiss spill announced with apocalyptic fury that states cannot seal their borders from environmental disasters.

Faced with the enormity and urgency of such international environmental problems the world has experienced a political awakening. Although environmental issues are not new for international relations, world leaders have increasingly brought environmental issues from the sidelines to the centre of their negotiation agendas. ${ }^{6}$ International conferences and treaties regarding global warming and ozone depletion are but few signs that the world has entered a new age of environmental diplomacy in which environmental issues will share centre-stage with more traditional economic and military concerns. ${ }^{7}$ In response to this concern governments, legislatures, and the courts have produced a labyrinth of draft bills, amendments to existing legislation, regulations, drafts of international treaties, and judicial decisions, all creating legal controls of pollution. 8

In order to ascertain scientific information and technological data royal commissions, presidential enquiries, governmental departments, and international agencies have undertaken extensive research programs. ${ }^{9}$ Paralleling these developments, international environmental law has started to become a new and an emerging academic discipline. A growing number of commentators, diplomats, and practitioners are concentrating on transboundary and global environmental issues. There has also been a significant increase in the number of law schools all over the world that have started focussing towards this subject. The regime of international environmental law

4 'Gas leak in India kills at least 410 in city of Bhopal' New York Times 4 December 19841.

5 'Lee, Chernobyl died of radiation burns, Soviets announce' Washington Post 13 May 19864.

6 Trail Smelter Case US v Canada (16 April 1938)(1938) International Arbitral Awards 3. For example, as early as 1927, the United States and Canada were embroiled in a dispute over the damage that a private smelting operation in British Columbia had caused to crops in the state of Washington.

7 W Danes 'Developments in the law: international environmental law' (1985) 104 Harvard Law Review 1484-1639.

8 J Yates 'Unilateral and multilateral approaches to environmental pollution' (1971) 21 The University Of Toronto Law Journal 182-192.

9 Yates (n 8 above) 182-192. 
is mainly composed of treaties, customs; general principles of international law and opinio juris. ${ }^{10}$ In an attempt to use customary international law to protect the environment, commentators have spent the last two decades in elaborating the rules of state responsibility and liability specifically to address the issues related to transboundary pollution. States have begun to build on this liability regime towards the development of international agreements designed to prevent harmful environmental activity. ${ }^{11}$

\section{Transboundary environmental pollution and the concept of state liability}

\subsection{An overview}

Pollution respects no jurisdictional boundaries. Air and water carry dangerous substances from one nation to another. Such transboundary pollution can arise from a single accident in one state that harms the environments of other states or from a continuous emission of substances that affects the environments of other states. ${ }^{12}$ Faced with pollution that knows no borders legal analysts have resorted to principles of international law, writ large, to develop a comprehensive framework of environmental protection. ${ }^{13}$

Under classical principles of international law, the obligation to prevent transnational pollution falls solely upon the state. ${ }^{14}$ Drawing upon international custom as the primary source of law publicists have sought to develop an international liability scheme to regulate transboundary pollution and have codified rules of customary international law to clarify the legal duty upon states to prevent serious transnational environmental harm. ${ }^{15}$ Efforts to develop an effective international liability scheme, however, have failed utterly. Publicists have presupposed that extrapolations from rules of customary international law coincide with the shared interests of the individual states upon whose participation a liability regime depends. Yet a regime constructed from custom obscures the differences between the conflicting values states assign to environmental protection. The codification of general customary duties founders upon this quandary of legitimacy.

10 Statute of International Court Justice of 1945 article 38.

11 ILC Draft Articles on Prevention of Transboundary Harm from Hazardous Activities (ILC Draft Articles).

S McCaffrey Pollution of shared natural resources (1977) 71.

J Brunpe Acid rain and ozone layer depletion (1988) 124.

$G$ Whetstone \& A Rosencranz "Transboundary air pollution: the search for an international response' (1984) 8 Harvard Environmental Law Review 120.

15 Black's law dictionary (1990) 1229. 'Publicist' is one versed in, or writing upon, International law. 
The International Law Commission has also come up with Draft Articles on State Responsibility for Internationally Wrongful Acts, whereby the liability is attributable to the state even if the said wrongful act is committed by its agents or for that matter, even by any private person under its direction and control. ${ }^{16}$ However, establishing any liability on the part of the state of origin is indeed very improbable, keeping in mind the fact that international law is basically composed of norms rather than obligations. In this light, faced with the failure to develop an operational liability regime, many publicists have attempted to broaden the scope of state responsibility. ${ }^{17}$ Unlike those traditional commentators who conceived the doctrine of state responsibility as applying after transboundary environmental injury has taken place, modern analysts have sought to impose procedural obligations upon states such as the duty to assess potential environmental harm to another state from domestic activity and the duty to inform other nations of activity threatening transboundary environmental injury. ${ }^{18}$

It is being submitted that the theoretical imposition of liability on states after damage has taken place fosters confrontation, undermines cooperation and fails to prevent the injury in the first place. ${ }^{19}$ The frontloading of procedural requirements, publicists argue, enables states to address transboundary pollution preemptively through a 'dispute-avoidance' system of mutual cooperation. ${ }^{20}$ This proliferation of procedural requirements, however, reflects a misunderstanding of the true defect in the current international liability regime: the regime has not structured incentives that make the benefits of membership outweigh the benefits of noncompliance in any single instance. The move toward procedural duties provides only a superficial gloss of international consensus. Procedural duties merely highlight the costs and benefits of a proposed activity and leave unanswered the critical normative question of how much weight state decision makers should place on the costs and benefits thus exposed. State compliance with procedures bears little relation to curtailing transboundary pollution, and by thus emphasising form over substance, international environmental law has veered toward irrelevance.

\subsection{State attribution and breach of duty}

To invoke state responsibility for extraterritorial pollution the complaining state must first establish that the offending conduct is

S McCaffrey 'The work of the international law commission relating to transboundary environmental harm' (1988) 21 International Law and Policy 115.

A Springer The international law of pollution (1983) 142.

Wetstone et al (n 14 above) 120.

My own emphasis.

Springer (n 17 above) 142. 
attributable to the defendant state. ${ }^{21}$ Next, the victim state must prove three further elements: breach of an international duty, a causal relationship between the conduct and the injury, and material damage. ${ }^{22}$ Because the causation and material damage requirements have also vexed many domestic nuisance systems, this section focuses on the efforts by publicists and world organisations to develop the doctrine of state attribution and to give content to a state's duty to prevent transnational pollution.

International jurisprudence has established that acts committed by a state's organs or agents in violation of an international obligation may be attributed to the state. ${ }^{23}$ The position of the state organ within the governmental structure does not alter the extent to which the conduct of the organ may be imputed to the state. ${ }^{24}$ For example, states may be held responsible for the conduct or omissions of their legislative bodies or their courts. ${ }^{25}$ Even ultra vires ${ }^{26}$ acts may be attributed to the state, ${ }^{27}$ as long as the state organ has acted with the state's apparent authority. The Tribunal in the Caire case ${ }^{28}$ proposed a two-pronged test for the attribution of ultra vires conduct to the state: the state agents or representatives must have acted, at a minimum, with the apparent authority of the state and the power or means used must have had an official character. The tribunal held that 'it is necessary that they acted at least apparently as competent functionaries or organs or that, in acting, they availed themselves of the powers or means corresponding to their official capacity.'

\subsection{Breach of duty and the principle of sic utere}

Under the principle of sic utere tuo ut alienum non laedas, ${ }^{29}$ a state has a duty to refrain from acts that would cause injury to persons or property located in the territory of another state. Even if the conduct in question can be attributed to the source state, the imposition of state responsibility requires the breach of an international obligation.

'La responsabilite internationale des etats de raison des dommages soufferts par des etrangers' (1906) 13 Revue Generale De Droit International Public 216.

22 G Handl 'Territorial sovereignty and the problem of transnational pollution' (1975) 75 American Journal of International Law 69.

23 R Dias \& B Markesinis Tort law (1989) 109.

24 Draft Articles on State Responsibility adopted by the International Law Commission on first reading of 1980 article 5 .

25 Draft Articles (n 24 above) article 6.

26 Webster's third new international dictionary (1986) 2480. 'Ultra vires' conduct here refers to activities 'beyond the scope or in excess of legal power or authority' vested in a state organ or representative. Draft Articles (n 24 above) article 10.

Case France v Mexico (13 June 1929) (1929) International Arbitral Awards 3.

Black's law dictionary (n 15 above) 1380. This principle dictates that 'one should use his own property in such a manner as not to injure that of another.' 
For transboundary pollution responsibility attaches to conduct attributable to the state that violates. ${ }^{30}$ The 1938 Trail Smelter Arbitration ${ }^{31}$ introduced the above principle into international environmental jurisprudence. In Trail Smelter the tribunal held Canada liable for the damage that a private smelting operation in British Columbia had caused to property in the United States but reserved judgment on an injunction against future pollution. After drafting a pollution abatement program in the first phase of the arbitration the tribunal issued an injunction against further operations and stated in dicta:

Under the principles of international law, ... no state has the right to use or permit the use of its territory in such a manner as to cause [environmental] injury ... in or to the territory of another or the properties of persons therein, when the case is of serious consequence and the injury is established by clear and convincing evidence. ${ }^{32}$

A few subsequent decisions by international courts and tribunals have ratified the sic utere principle in international law. ${ }^{33}$ International legal scholars have similarly asserted that transboundary pollution violates principles of customary international law. Indeed, the 1987 Restatement (Third) of the Foreign Relations Law, whose principles for environmental law 'are rooted in customary international law,' ${ }^{34}$ specifies that a state must take all necessary measures, to the extent possible, to prevent activities within its jurisdiction or control from causing significant injury to the environment outside its jurisdiction.

Moreover, states have ratified international treaties and declarations reaffirming the obligation to prevent significant transboundary injury. For example, Principle 21 of the Stockholm Declaration on the Human Environment of $1972,{ }^{35}$ recognised today as the codification of a rule of customary international law, imposes upon states a 'responsibility to ensure that activities within their jurisdiction and control do not cause damage to the environment of other states' or the environment of any area beyond their jurisdiction.

30 R d'Arge \& A Kneese 'State liability for international environmental degradation: an economic perspective' (1980) 20 Natural Resources Journal 429-430.

31 Trail Smelter Case US v Canada (April 16 1938) (1938) International Arbitral Awards 3.

32 d'Arge (n 30 above).

33 Corfu Channel Case UK v Albania (April 9 1949) (1949) ICJ Reports 4. Affirming 'every state's obligation not to allow knowingly its territory to be used for acts contrary to the rights of other states.' Many commentators interpret Corfu Channel as establishing a principle of state responsibility for transboundary pollution.

$34 \mathrm{~J}$ Kindt Restatement (third) of the foreign relations law of the United States (1987) 601-604.

35 Stockholm Declaration on the Human Environment (Stockholm Declaration). 


\subsection{The stillborn regime of international liability}

The last two decades have witnessed the proliferation of scholarly literature on international liability for transnational pollution. ${ }^{36}$ Scholars have treated the subject as if an actual regime exists for adjudicating disputes and imposing liability upon a state for activities within its jurisdiction or control that injure the environment of another state. Meanwhile, the International Law Commission (ILC) of the United Nations has set its thirty-four experts to the task of codifying doctrines of state responsibility and international liability from customary international law. ${ }^{37}$ Other international organisations, such as the Organisation for Economic Cooperation and Development (OECD), the United Nations Environment Programme (UNEP), and the World Commission on Environment and Development (WCED), have similarly extrapolated rules of liability for states from customary practices, general principles of law, treaties, charters, and international judicial decisions.

Notwithstanding the close attention that the international legal community has given the issue of international liability for transboundary pollution, no operational system for adjudicating liability has emerged. The International Court of Justice (ICJ) has heard only one dispute, the Nuclear Tests ${ }^{38}$ case; and international arbitration has entertained only a few notable cases, principally the Trail Smelter ${ }^{39}$ Lake Lanoux, ${ }^{40}$ and Gut Dam ${ }^{41}$ arbitrations. No state even brought suit against the Soviet Union following the 1985 Chernobyl accident, although more than twenty states registered significant increases in radioactivity levels.

Moreover, the scant international environmental case law that does exist possesses little precedential value because the cases are decided not on environmental liability grounds but rather on narrow treaty grounds. Thus, neither scholars nor international judges can legitimately rely upon these cases to generate more specific liability rules. 42 The scarcity of noteworthy decisions and their limited precedential value have stifled doctrinal development and rendered an embryonic liability system unable to communicate expectations about the consequences of action or inaction to prospective polluting states. national environmental policies' (1981) 79 Transboundary Pollution and the Role of States 93.

37 McCaffrey (n 16 above).

38 Australia v France ICJ (20 December 1974)(1974) ICJ Reports 457

39 d'Arge (n 29 above).

40 France $v$ Spain (16 November 1957)(1957) 24 ILR 101

41 Gut Dam Claims Canada v United States of America (27 September 1968)(1969) 8 ILM 118.

42 Yates (n 8 above) 148. 
The dearth of case law deprives the principle of sic utere of the specificity that applications to particular instances of transboundary pollution would arguably furnish it. However, the illusory nature of liability for transboundary environmental harm hardly stems from a simple failure to develop specific content for the principle of sic utere. Rather, the lack of case law reflects the refusal of states to countenance even the partial relinquishment of sovereignty that submission to binding third-party adjudication would entail. ${ }^{43}$ States will not submit to such adjudication unless they have already entered into a binding treaty entitling one party to seek redress in an international tribunal, which is an exceedingly rare occurrence. ${ }^{44}$

\section{International environmental agreements: creation and enforcement}

\subsection{An overview}

International environmental agreements are the predominant legal method which may be employed to solve transboundary environmental issues in the best possible way. In this part the word 'international' would mean agreements between two or more states or international organisations such as the European Economic Community, or for that matter, any other. Such agreements can be classified roughly as bilateral (between two states), regional (among more than two states sharing geographic proximity), or global (among more than two states not sharing geographic proximity). Further, 'agreement means any agreement in written form and governed by international law'; all treaties fit this definition of agreement, as do many agreements called (somewhat misleadingly) conventions and protocols. 45

In the first half of the twentieth century there was a stress on mainly the bilateral treaties, which included mostly local aspects such as acid rain or a shared physical resource such as a river or a lake. ${ }^{46}$ However, as environmental problems become increasingly global in nature broader agreements pertaining to the oceans, the atmosphere, the global climate, Antarctica, and endangered species will assume a greater role in the preservation of the earth's environment. Further, as the world is moving steadily towards globalisation there has been an emerging need for treaties that also have a global character. However, there are a lot of hurdles and

43 Eastern Carelia Finland v USSR (23 July 1923) (1923) PCIJ 527.

44 Springer (n 17 above) 157.

45 The Vienna Convention on the Law of Treaties of 1969 article 2(i)(a).

$46 \mathrm{R}$ Bilder 'The settlement of disputes in the field of the international law of the environment' (1975) 144 Recueil Des Cours D' Acadgmie Dedroit International 139-168. 
roadblocks in the creation and enforcement of such multilateral treaties, which further point towards the fact that international environmental law is a stillborn regime. In this part we would examine the problems that arise in the creation of international environmental agreements and the methods used to reduce or avoid those problems.

\subsection{Creation of international agreements: law and the process}

International agreements are created in two stages: representatives first meet to negotiate a text of the agreement and states then ratify it. International law, however, does not specify how to implement this two-step process. The primary sources of law governing the creation of international agreements are the 1969 Vienna Convention on the Law of Treaties 47 and the 1986 Vienna Convention on the Law of Treaties between States and International Organizations or Between International Organizations. ${ }^{48}$ The former applies to agreements between states and the latter to agreements involving international organisations such as the United Nations, ${ }^{49}$ but they are virtually identical in substance. Under both conventions, states and international organisations have the capacity to enter binding agreements but cannot be bound by any agreement without their consent.

A state or international organisation that seeks to enter into an agreement must send a valid representative to negotiate an authentic text of the agreement. Once the negotiations produce an authentic text, each state may express its consent to be bound by the agreement, usually by ratifying it, and may enter reservations that alter the terms of the agreement. Beyond these basic requirements, the Vienna Conventions do not mandate any particular processes of negotiation or ratification. Thus, each state is free to select its own method of ratifying agreements. Given the diversity of methods it may take several years before enough parties ratify an agreement for it to enter into force. Although, every state that signs an agreement has an obligation to refrain from acts, which would defeat the object and purpose of the agreement until it enters into force; the details of this obligation remain vague. Moreover, signatory states are not required to take affirmative actions to comply with agreements that have not yet taken effect. Thus, delay pending ratification can render environmental agreements ineffective if the underlying environmental problem worsens or

Springer (n 17 above).

Vienna Convention (n 3 above) article 6.

I Sinclair The Vienna Convention on the Law of Treaties (1984) 10-20. Examining the extent to which the 1969 Vienna Convention was codification of customary law or progressive development. 
becomes irreversible. States occasionally even reverse their position and refuse to ratify agreements they have negotiated. The United States' ratification process illustrates how problems of delay or reversal may arise.

Because most multilateral environmental agreements are article II treaties, not executive agreements, two- thirds of the Senate must consent for the United States to ratify them. In some instances, the Senate has explicitly rejected international agreements reached by the President. On other occasions, the President has not attempted to obtain the Senate's consent to a treaty in light of indications that the treaty would be rejected. ${ }^{50}$ More often, the Senate has imposed conditions on its consent to ratification. A condition may require the President to formulate a reservation. In which case, the United States can become a party to the agreement only if other parties accept the reservation. ${ }^{51}$ The formulation of such a reservation may reopen political issues resolved during the original negotiations. ${ }^{22}$ Thus, the United States' ratification process not only may delay the entry into force of an agreement but also may jeopardise its very existence.

\subsection{Special characteristics of environmental problems}

\subsubsection{The interaction of science and politics}

Environmental agreements differ from many other types of agreements because they respond to scientific evidence of a problem. The unique role of scientific evidence places conflicting demands on the negotiation process: negotiators need sufficient data to understand the problem and to formulate effective solutions, but they may have to act quickly to prevent the problem from worsening or becoming irreversible. ${ }^{53}$ Because scientific evidence is always somewhat uncertain, and because research is expensive and time-consuming, states face a dilemma: to act in the face of uncertainty or not to act at all. States must develop methods of dealing with uncertainty that do not always result in delay and inaction. One common method of dealing with uncertainty is to apply an expected-value calculation. ${ }^{54}$ For example, oil companies often must decide whether to drill when they are uncertain if a given site contains oil. Assume the cost of drilling is $\$ 5000$ per well, the probability of striking oil is ten percent for each well, and the value of an oil-producing well is $\$ 100000$. If an oil company drills 100

50 'US is ready for 1st round of missile talks' Washington Post 8 September 198029. Haver v Yaker 76 US 32 (1870) 35.

L Henkin Constitutionalism, democracy and foreign affairs (1990) 51.

R Benedick Ozone diplomacy: new directions in safeguarding the planet (1991) 201.

54 F Hillier \& G Lieberman Operations research (1974) 597-601. 
wells at a total cost of $\$ 500000$, it will on average strike oil ten times for a total value of $\$ 1000000$. Under these circumstances the company's net profit would be $\$ 500000$. Because the project has a positive expected value, the company should drill the 100 wells. In the context of environmental regulation, an expected-value calculation would require states to estimate the magnitude of damage resulting from an environmental problem and to multiply that estimate by the estimated probability that the damage will occur. States would then compare the expected value of the damage to the costs of preventing or reducing the problem and try to achieve a solution that minimises total costs plus damages. It is often difficult, however, to quantify precisely the harm to environmental resources.

Even when states do attempt to address environmental problems, they face a wide range of estimates of the resulting environmental damage. In seeking to minimise the costs of regulation some states may insist upon the estimates at the lower end of the range. If subsequent international agreements are based on these estimates, they will represent lowest-common-denominator solutions to environmental problems that systematically yield under regulation. ${ }^{55}$

Thus, states should resist the tendency to compare the relatively certain and easily quantifiable costs of environmental regulation with the most optimistic predictions of damage. ${ }^{56}$ This is not to suggest that states should take all steps, no matter how costly, to prevent the worst-case scenario. Rather, they should make policy choices in light of all available information - the full range of estimates of environmental harm as well as the probability that these estimates are correct - recognising that the costs of environmental regulation will reduce or eliminate the possibility of damage.

\subsubsection{The use of global commons}

Another characteristic that distinguishes many environmental agreements from other agreements is that environmental agreements involve global commons - shared resources or resources that affect the international community as a whole. Because the management of such resources often requires international cooperation, it raises problems of states that render international agreements ineffective by refusing to cooperate (hold-outs) and states that enjoy the benefits of international regulation while refusing to share the costs of regulation (free riders). ${ }^{5}$

55 Hillier et al (n 54 above) 609-610.

56 R Benedick Ozone diplomacy: new directions in safeguarding the planet (1991) 201.

57 S Maurice \& O Phillips Economic analysis theory and applications (1986) 607-608. 
Hold-out problems are especially acute in the environmental context because hold-out states can not only prevent other states from reaching effective agreements, but also exacerbate the underlying environmental threat. ${ }^{58}$ There are three types of global commons, each of which raises different regulatory challenges. The first consists of resources such as the tropical rain forests in Brazil and the herds of elephants in Africa that are contained within the territorial boundaries of one state or group of states but have an impact on the global environment. The destruction of the Brazilian rain forests could alter global temperatures, for example, and the extinction of African elephants would diminish the rich diversity of the earth's wildlife. Some scholars argue that the best way to preserve such resources is to privatise them. ${ }^{59}$ Others believe that these resources belong to the possessor states to manage as they please. ${ }^{60}$

The second type of global commons is unallocated commons resources such as Antarctica and parts of the oceans in which no state has property rights. For such resources the main issue is not whether their use should be subject to international regulation, but rather who should control such regulation. In the 1970s, for example, technological advances raised the possibility of exploiting Antarctica's marine and mineral resources, which led to the negotiation of the Convention on the Conservation of Antarctic Marine Living Resources (CCAMLR) ${ }^{61}$ of 1982 and the Convention on the Regulation of Antarctic Mineral Resource Activities (CRAMRA). The parties to these negotiations were the consultative parties to the 1959 Antarctic Treaty. The primary issue raised by the negotiations of CCAMLR and CRAMRA was who should decide how to regulate the use of Antarctica's natural resources. The Law of the Sea experience made the parties to the Antarctic Treaty wary of expanding the decision making process to include more states. ${ }^{62}$ However, these states were sensitive to arguments that Antarctica is part of the 'common heritage of mankind,' and as such should be regulated by an international agreement of all states. ${ }^{63}$ As a result, the parties to the Antarctic Treaty attempted to achieve a reasonable trade-off

58 Maurice (n 58 above).

59 W Block Environmental problems, private property rights solutions (1990) 309318.

60 'Brazil agrees to accept aid to save rain forests' New York Times 5 February 1989 3. For example, until 1989 Brazil resisted foreign involvement in the Amazon rain forests and even when President Sarney agreed to debt-for-nature swaps military leaders in Brazil still voiced the opinion that '[e]verytime someone in the US says the Amazon belongs to mankind, it becomes more difficult here to have a rational discussion.'

61 Maurice (n 57 above).

62 United Nations Convention on the Law of the Sea (UNCLOS).

63 G Richards 'Thaw in international law: rights in Antarctica under the law of common spaces' (1978) 87 Yale Law Journal 804-828. 
between responsible trusteeship by the few and equitable sharing among the many.

The third type of global commons is 'true commons' - resources such as the atmosphere and the global climate that are not contained in any one state and for which allocation of property rights remains impossible. The regulation of true commons by international agreement poses serious hold-out and free rider problems. For example, because the technology of producing chlorofluorocarbons (CFCs) is easily mastered, any agreement to reduce future CFC production would be futile without the cooperation of highly populated states such as China and India that will someday have a large demand for CFCs and the technological capacity to produce CFCs. ${ }^{64}$

Hold-out problems frequently necessitate lowest-commondenominator solutions that result in under regulation. ${ }^{65}$ The Montreal Protocol demonstrates one attempt to avoid this result. By imposing higher regulatory requirements on industrial states than on developing countries, negotiators reached an agreement that was acceptable to all states and still provided for substantial CFC reductions. ${ }^{66}$ This method of avoiding lowest-common-denominator solutions may be effective as long as industrialised states are willing to bear an unequal share of the cost of environmental regulation. Theoretically, customary international law could reduce the problems hold-outs cause by creating rights and obligations for states that do not join the agreement. Some scholars now contend that states have a right under customary international law to declare 200 mile EEZs regardless of whether they sign the Law of the Sea Convention or whether it ever enters into force. ${ }^{67}$ The United States maintains this position as well; citing the existence of a right under customary international law, President Reagan proclaimed an EEZ for the United States in 1983 even though the United States was not a party to the convention. ${ }^{68}$

However, it is unlikely that the application of customary international law will prevent hold-out problems in most environmental negotiations. Although, states may be willing to accept the creation of general rights such as EEZs by customary law, they may resist the imposition of specific obligations. Furthermore, there is little customary international law to be codified regarding

64

65

66

67

68

W Nitze 'A proposed structure for an international convention on climate change' (1977) 35 Harvard Law Review 45.

P Sand International cooperation: the environmental experience, in preserving the global environment (1991) 250-251.

Montreal Protocol on Substances that Deplete the Ozone Layer (Montreal Protocol).

(1989) 27-37.

Springer (n 17 above). 
the global environment, and it is unlikely that states will develop a consistent practice of managing global commons during negotiations. Finally, because obligations under a global environmental agreement are likely to be part of a 'package deal' of compromises between industrial states and developing countries, ${ }^{69}$ any assertion that some elements of that package have become customary law through state practice while others have not threatens to upset the balance of interests achieved by the negotiations. ${ }^{70}$

\subsubsection{The interests of future generations}

Environmental policy is designed in part to preserve the environment for future generations. This is because future generations are not present during the creation of international agreements; members of the current generation must represent their interests. The representation of future interests raises two basic problems. First, it is difficult for members of the current generation to measure the interests of future generations. Second, states must decide who will make these value judgments on behalf of future generations. There are two extreme models of the obligation the current generation owes to future generations; both are incompatible with the goal of reaching agreements to preserve the environment. At one extreme is the preservationist model: the current generation must preserve all resources for the future. ${ }^{71}$ This model would preclude an industrial economy, which requires that the current generation consume or degrade some resources. ${ }^{72}$ At the other extreme is the opulent model: the current generation is entitled to exploit resources however it wants. This model denies any obligations to future generations. ${ }^{73}$

Recently, commentators have proposed a third, intermediate model: the theory of 'intergenerational equity'. ${ }^{74}$ This model is based on the idea that states should determine intergenerational rights and obligations from general principles, as if they did not know to which generation they would belong. There are three basic principles of intergenerational equity: each generation must conserve the diversity of the base of natural and cultural resources (conservation of options), each generation must maintain the quality of the planet (conservation of quality), and each generation must provide its own members with equal access to resources and must conserve this access for members of future generations (conservation of access). ${ }^{75}$

H Caminos \& M Molitor 'Progressive development of international law and the package deal’ (1985) 79 American Journal International Law 871-879.

Kwiatkowska (n 67 above).

E Weiss In fairness to future generations (1989) 22.

Weiss (n 71 above).

Weiss (n 71 above) 23.

Kwiatkowska (n 67 above). 
According to this view, 'the human community is a partnership among all generations,' and 'the purpose of human society [is to] protect the welfare ... of every generation. ${ }^{, 76}$ Even if the theory of intergenerational equity correctly resolves the balance between the interests of current and future generations, it does not provide much guidance for measuring future interests. The value of natural resources to each generation depends on how that generation uses them. It is impossible for the current generation to predict how future generations will use such resources because technological advances may dramatically increase the value of some resources and decrease the value of others. ${ }^{77}$

A better approach would encourage states to make policy decisions based on estimates of the total costs of environmental regulation and the anticipated total damage to the resources in question. Suppose, for example, that India and Pakistan are negotiating an agreement to preserve river Indus. Assume that Indus is currently polluted and that the total cost to both states of restoring it to a pristine state in 100 years is one million dollars. For the sake of future generations, the two states should decide whether together they would pay one million dollars to have clean Indus 100 years from now. If so, they have an obligation to future generations to begin the clean-up. In seeking to fulfil that obligation the two states could then decide how to share the costs.

\subsubsection{The conventional approach}

Due to the apparent success of the recent ozone negotiations the convention-protocol approach has become the favoured method of creating multilateral environmental agreements. Although the convention-protocol approach may be an improvement on the Law of the Sea negotiations, it still leaves some problems unsolved. Its weaknesses suggest that it may fail to produce an effective agreement in the upcoming global warming negotiations.

Admittedly, the convention-protocol approach might solve some of the problems that occur in the creation of environmental agreements. For example, it could reduce free rider problems by inducing states to enter a relatively costless agreement (the convention) as a prelude to more costly ones (the protocols). Presumably, once states are parties to a convention, they will be under greater pressure and thus more likely to join protocols reached at subsequent conferences. In addition, the ozone negotiations culminating in the Montreal Protocol seemed to show that the

75 Weiss (n 71 above).

76 D Baird 'Self-interest and cooperation in long-term contracts' (1990) 19 Journal Legal Studies 583-585.

77 Baird (n 76 above). 
convention creates a framework of cooperation in which states can reach agreement quickly when new scientific evidence becomes available, thus enabling them to respond to environmental problems before the damage becomes much worse or irreversible. ${ }^{78}$

The convention-protocol approach, however, has not met complete success. No African state except Libya has signed the 1989 Basel Convention, even though the agreement was negotiated at the insistence of developing countries. ${ }^{79}$ Even the convention-protocol agreement most widely considered to be a success, the Montreal Protocol, may ultimately prove a hollow victory. Although the negotiations quickly produced an agreement, it remains to be seen whether that agreement will achieve the stated goal of preventing further depletion of the ozone layer. Some scientists and environmentalists believe that the CFC reduction targets adopted in the Montreal Protocol will be 'too little too late' ${ }^{80}$ Moreover, the convention-protocol approach has inherent weaknesses that may undermine future negotiations.

First, two rounds of ratification are necessary before any environmental regulation enters into legal force (one for the convention and one for the protocols), and the environmental problem may become irreversible in the interim. Thus, the appearance that the convention-protocol approach leads to agreements more quickly than comprehensive negotiations is deceiving. The relevant time frame starts with the beginning of the convention negotiations and lasts until the protocol enters into force. The ozone regime thus took nearly eight years to go into effect. Second, although the convention-protocol approach may reduce free rider problems, it does not reduce the threat of hold-outs in the regulation of global commons. An incumbent government may join the convention to share in the domestic political rewards of reaching an agreement without ever joining a protocol and incurring the costs of environmental regulation. This problem may be solved by requiring every party to the convention to be party to at least one protocol; in fact, some conventions include such a provision. ${ }^{81}$ But parties could still join only those protocols that are favourable to them. For example, under the Convention on

The Montreal Protocol negotiations culminated in an agreement in less than two years after the discovery of the hole in the ozone layer above Antarctica.

79 C Hilz \& M Radka 'The Basel Convention on transboundary movement of hazardous wastes and their disposal' (1989) 75 Nine Case Studies 91-92.

80 'Polar thinking on the antarctic' New York Times 17 October 1989 27. In the recent negotiations of the Convention on the Regulation of Antarctic Mineral Resource Activities (CRAMRA), for example, the parties took six years to reach agreement. Due to lobbying by environmental groups, two key signatories Australia and France have indicated that they will not ratify the Convention.

81 S Fitzgerald International wildlife trade: whose business is it (1989) 377. 
International Trade in Endangered Species (CITES), ${ }^{82}$ any state can enter a reservation to a change in the lists of protected species (the CITES equivalent of protocols) and thereby exempt itself from the Convention with respect to that species. ${ }^{83}$ As a result, the effectiveness of CITES has been severely limited by Japan's reservations regarding four species of whales and the reservations of five African states regarding African elephants.

\section{Unilateral and multilateral approaches to mitigate transboundary pollution}

\subsection{An overview}

In the previous chapters we have discussed the problem of transboundary pollution and the inherent difficulties in the mechanisms for mitigating with the same. Nevertheless, when sufficient scientific and technological knowledge has been ascertained and subsequently the dangers defined, it will become the task of the jurist to provide the necessary safeguards against pollution hazards. It is with hesitation, then, that one comments and speculates on future possibilities. However, one conclusion is obvious, the task of providing adequate legal controls of pollution will be difficult: the problems are diverse and the dangers great. ${ }^{84}$ In the current chapter we will try to explore the various extraterritorial regimes that can cooperate with each other in order to mitigate the ever-growing environmental hazards. This includes both unilateral as well as multilateral approaches.

\subsection{Extra territorial environmental regime}

The body of customary norms and international agreements that comprise the public international legal system do not provide comprehensive environmental protection. In those areas in which public international law do not protect the environment; international environmental protection is only as strong as the sum of individual states' domestic environmental regimes. ${ }^{85}$

Consequently, any treatment of international environmental law must consider how domestic environmental regimes may add to the protection of the global environment. The efficacy of an international

82 The Convention on International Trade in Endangered Species of Wild Flora and Fauna (CITES).

83 M Glennon 'Has international law failed the elephant' (1990) 84 Journal International Law 5-6.

84 Anzilotti (n 21 above).

$85 \mathrm{G}$ Handl 'State liability for accidental transnational environmental damage by private persons' (1980) 74 Journal International Law 564 - 565. 
regime constructed from the environmental regulation of individual states will depend on two factors. First, each country must set stringent standards and must extend the protection of its standards to foreign citizens injured by transboundary pollution emanating from that country. Second, each country must have the power to enforce these standards domestically. In recent years environmentalists have criticised the international community's reliance on a regime that depends on the ability and willingness of each state to regulate the potentially harmful activities that occur within its own borders. Commentators note that this system would work well if every state had a strong environmental regime and provided foreign citizens equal access to its domestic procedures for seeking redress. ${ }^{86}$ They conclude, however, that an international system consisting of discrete national policies fails to protect the environment because some states have weak environmental regimes - that is, some states either set low environmental standards, do not allow foreign citizens to invoke these standards, or lack the power to enforce these standards. To remedy these weaknesses environmentalists and commentators have urged states with strong environmental regimes, such as the United States, to extend the reach of their legal systems to govern conduct in other countries. This approach circumvents the need to secure foreign states' adherence to strict environmental standards set forth under public international law. Instead, it simply subjects individuals acting in territory governed by weaker regimes to the stricter environmental standards of other states. States can extend the reach of strong domestic regimes by two means: extraterritorial legislation and extraterritorial adjudication. These methods are collectively referred to here as extraterritorial regulation.

\subsubsection{The rise of extraterritorial environmental regulation}

A state with a strong environmental regime can regulate extraterritorially in two distinct ways: through legislation and adjudication. A general understanding of how domestic environmental legislation and adjudication operate in both strong and weak environmental regimes may be helpful for understanding the details of extraterritorial regulation.

Most countries have enacted some sort of regulatory regime that establishes environmental standards for domestic activities. ${ }^{87}$ The amount of environmental protection that these laws provide,

S McCaffrey 'Transboundary pollution injuries: jurisdictional considerations in private litigation between Canada and the United States' (1973) 3 California Western International Law Journal 224-229.

87 G Kopp et al Comparing environmental regulation in the OECD countries (1990) 10. 
however, varies widely among countries. For example, the United States heavily regulates domestic land use in order to prevent air, water, and noise pollution. ${ }^{88}$ Similarly, the United States regulates the domestic use of environmentally hazardous items such as chemicals and pesticides by requiring that these items be approved by the EPA as environmentally acceptable before they are sold in the domestic market. By contrast, many states have adopted significantly more lenient pollution standards. ${ }^{89}$ For example, many allow the use of pesticides such as DDT that the United States has prohibited as environmentally unacceptable. ${ }^{90}$ Domestic regimes differ not only in the standards they set, but also in the effectiveness of their enforcement. Even stringent standards require robust enforcement mechanisms to ensure adequate protection. ${ }^{91}$

Although many states have created agencies to enforce environmental regulations, many of these agencies lack the resources and expertise to detect and prosecute violations.

\subsubsection{Adjudication}

Most states also provide some system of adjudication in which private harm - including environmental harm - can be redressed through the courts. ${ }^{92}$ Whether adjudication successfully protects the environment depends in part on the substantive rules that govern liability. The most protective rule is strict liability, which most American courts will apply to an environmentally hazardous activity. Under a strict liability rule courts require polluters to pay for the damage they cause whether or not their behaviour was reasonable. ${ }^{93}$ In knowing this polluters normally minimise their liability for environmental harm either by reducing the level of harmful activity or by employing technology to reduce the activity's ill effects. Many states employ a negligence rule. According to which polluters are forced to pay only if the polluting activity was conducted without reasonable care. Both rules provide a deterrent to potential excessive polluters, although the deterrent effect is greater under strict liability. The level of protection can vary considerably among states that apply a negligence rule. ${ }^{94}$

89 . Rodgers Handbook on environmental law (1997) 208- 618

89 C Kuku 'Environmental planning for industry in a developing country' (1983) 49 International Business Law 49.

Kuku (n 89 above).

Kuku (n 89 above).

Rodgers (n 88 above).

Vienna Convention (n 3 above) article 6.

W Keeton et al Prosser and Keeton on torts (1984) 175-220. 


\subsubsection{The need for and power of extraterritorial regulation}

Public international law has traditionally limited its concern to environmental harm that spreads from one state to another, such as drifting smoke, and harm that affects the global commons, such as the destruction of the ozone layer. ${ }^{95}$ Environmentalists contend that extraterritorial regulation should apply not only to these harms but also to environmental harms contained within the territory of a single state, such as the destruction of a lake. They argue that the environmental threat posed by weak regimes is never purely local because the global environment is interconnected. ${ }^{96}$ In addition, they claim that the operation of competitive international markets means that the existence of weak environmental regimes undermines the willingness of any state to enact stricter environmental standards. Because firms subject to rigid environmental regulation are likely to have higher costs than firms in a country with little regulation, domestic political pressures to equalise the commercial playing field by relaxing standards may result in a race to the bottom in environmental regulation. ${ }^{97}$

\subsubsection{Extraterritorial adjudication}

As a general practice, three conditions must be met for plaintiffs to obtain effective extraterritorial adjudication: first, the respective courts must have jurisdiction to hear the case; second, the substantive environmental law being applied must be strong enough to establish liability; and third, courts must be able to enforce the judgment against the polluter. An analogous case has arisen in the environmental context. In Dow Chemical Co. v Alfaro ${ }^{98}$ Costa Rican farm workers were permitted to bring suit in a United States court for injuries caused by a pesticide manufactured in the United States and exported to Costa Rica. Filing suit in the United States was clearly more favourable to the Alfaro plaintiffs because American attorneys were willing to represent the injured indigent farm workers for a contingency fee and because litigating in the United States allowed the plaintiffs to avoid a $\$ 1500$ cap that Costa Rica places on recovery in personal injury cases. Environmentalists believe that suits of this sort will reduce United States corporations' willingness to export environmentally hazardous pesticides. Pepsi was sued in United

95 D Caron 'The law of the environment: a symbolic step of modest value' (1989) 14 Yale Journal of International Law 528.

96 O Kurup 'Environmental Protection Act: a scientist's view' (1987) 2 Cochin University Law Review 13.

97 Unpublished: J Kalt 'The impact of domestic environmental regulatory policies on US international competitiveness' Unpublished: 'Energy \& environmental policy centre discussion paper' on file at the John F Kennedy School of Government Library (1985) 30-32.

98

Dow Chemical Co. v Alfaro 768 US 674 (1990). 
States for a bottle that exploded in Jamaica. ${ }^{99}$ The jurisdictional bases for extraterritorial environmental regulation have been augmented by the courts' ability to pierce the corporate veil. Because a corporate parent and its subsidiary are two distinct entities that may have different citizenships, a United States court might lack jurisdiction over a foreign corporate entity. Using doctrines of alter ego 100 and agency, however, courts can extend their reach to environmental activities that occur abroad. ${ }^{101}$ For example, in re Union Carbide Corporation Gas Plant Disaster ${ }^{102}$ Indian plaintiffs, injured by a cloud of toxic gas released from a pesticide factory owned by Union Carbide of India (UCIL), brought suit in United States courts against the American parent, Union Carbide Corporation (UCC). ${ }^{103}$ Bypassing capital poor UCIL ${ }^{104}$ whose contacts with the United States might not have been sufficient to justify jurisdiction in American courts. ${ }^{105}$

\section{Conclusion}

In light of the previous chapters, it can be asserted that International agreements and extra territorial regimes will play a major role in any solution to worldwide environmental problems such as transboundary pollution. The international law governing the creation of international agreements allows states to choose among many methods of adopting various conventions. However, the international law relating to the environment, though not a stillborn regime, does not have any teeth because of the inherent difficulties in creation and implementation of the various multilateral agreements.

Keeping the above in mind, the public international legal system is of only limited effectiveness in encouraging sovereign states to improve their environmental regimes. In such a scenario, extraterritorial regulation by states with strong environmental regimes may seem intuitively useful. To the extent that extraterritorial environmental regulation supplements the contribution of public international law to environmental protection; it would be a welcome interim development. The ultimate goal, however, must remain the development and strengthening of each state's own regulatory regime. ${ }^{106}$

100 White $v$ Pepsico 866 US 325 (1989).

B Barmer 'Piercing the corporate law veil: the alter ego doctrine under federal common law' (1982) 95 Harvard Law Review 853.

101 G Born \& D Westin International civil litigation in United States courts (1989) 404405.

102 (12 May 1986)(1986) 54 USLW 2586.

103 Born et al (n 101 above).

$104 \mathrm{~J}$ Westbrook 'Theories of parent company liability and the prospects for an international settlement' (1985) 20 Texas International Law Journal 321 -327.

105

Birnie et al International law and the environment (2004) 365. 
Another regime, which needs attention and significance, is that of international custom. They serve as a promising point of departure for the elaboration of a liability system. After all, the very concept of international custom assumes nearly unanimous acceptance of certain practices ${ }^{107}$ and thus a quasi-participation of states in an implicit, unstated regime. Yet rules of customary international law rarely specify required behaviour. Rather, these rules state international duties that are too vague to provide any guidance about what behaviour is acceptable or to facilitate ready application of these rules to specific disputes. ${ }^{108}$ When publicists endow these abstract duties with substantive content and attempt to generate determinate outcomes for future disputes, they inevitably privilege the interests of some states over others.

However, an area of concern in this regard is the fact that many developing nations refuse to consider themselves bound by rules of customary international law, however determinate the rules may be. In particular, newly independent states regard such rules as relics inherited from the wealthy, powerful states of a bygone era of colonialism and imperialism. ${ }^{109}$ Such resistance undermines the assumption that states accepted, implicitly or explicitly, customary international duties upon entering the community of nations. This resistance by the developing nations is especially acute in the context of international environmental law. Developing countries often regard the application of customary international law to transboundary pollution as an attempt by developed nations to curtail Third World industrial growth.

At the 1972 Stockholm Conference, for example, developing countries resisted the imposition of environmental standards created by the industrialised powers. The Brazilian delegate at Stockholm declared that '[his] country had no interest whatever in the subject of pollution control,' which he viewed as a 'rich man's problem.' Although developing nations have begun to moderate their opposition to environmental protection, they continue to regard customary principles of environmental protection as infringements on their development. This reluctance to be bound by the principles of customary law would further create many roadblocks in the implementation of the various principles of State liability and responsibility as is quite visible in all the draft articles of the International Law Commission, as discussed earlier. So, the need of the hour is the mediation between the need for specificity and the

106 N Ashford \& C Ayers 'Policy issues for consideration in transferring technology to developing countries' (1985) 12 Ecology Law Quarterly 871-875.

107 L Sohn 'Generally accepted' (1986) 61 Washington Law Review 1073-1074.

108 K Hakapaa Marine pollution in international law (1981) 137.

109 A Biswas 'Environment and law: a perspective from developing countries' (1984) 11 In the Future of the International Law of the Environment 389-391. 
need for international acceptance which is the biggest hurdle in the path of codification of the state responsibility doctrine and the sic utere principle.

Lastly, it may be summed up that the issue of transboundary pollution is neither new to the global community nor is any state immune from the same. Despite all this and the various efforts made by the United Nations in creating a regime of environmental law, which would deal with all the issues related to transboundary pollution, the ground reality is that even today we have not made the kind of progress that should have been. The plethora of conventions, protocols and treaties that we have on this subject become meaningless if the state do not take them seriously.

Hence, it is time for the world to see the writing on the wall and create unilateral and multilateral mechanisms to prevent and mitigate the transboundary hazards from becoming disaster. The following words have the entire research work summed up and would be the best to be the closing lines of this research work:

Perhaps it is the collective menaces, arising from the world's scientific and technological strides and from their mass consequences, which will bind together nations, enhance peaceful cooperation and surmount, in the face of physical danger, the political obstacles to mankind's unity. ${ }^{110}$

110 Statement by $U$ That, United Nations Secretary-General, at opening of the Preparatory Committee United Nations Conference on the Human Environment (1970). 



\title{
ROSE TINGED MEMORIES: A FAMILY OF STRANGERS
}

\author{
by Nozuko Siyotula*
}

I took a drive to that dusty street whose length had once been filled with many families. To own the truth, I was led there by a longing to eat freshly baked cake in maTema's kitchen with the banana tree that blocked the light from the window and feel her motherly gaze from behind her sixties styled pink sunglasses.

A decade had passed since I was there last. So much had been happening then in the country. So much change in the air. That's the reason why we left, because staying meant accepting that life was always going to be the way it was and for us and for uMama it became a bitter pill. Ironically I had been led there now by a need to breathe in the familiar. To drive past houses where I knew how the furniture was arranged inside or how the black and white wedding photo hung so precariously on the nail hammered into the wall. I wanted to laugh about the day Bra Simon and Bra John had the whole street running out of our houses in our underwear going to intervene in their latest fray, once, long ago. I wanted the dust to cover my car and be the nuisance I remembered it to be, engulfing us in its restlessness.

Turning into the street I found it tarred and I felt instantly that I had been away for a while. All the neighbours had extended their houses or were in the process of doing so. There were still a myriad of colours of the painted houses competing to be noticed, the elaborate details of the metal gates and chained dogs in case there was a visitor during the day and at night, in case there was a thief. The dogs sat with their heads resting on their stretched out forelegs waiting for either. I arrived at maTema's house, two houses down from where I had once lived. I parked my car.

The working class have always been an aspirant class but with little or no opportunity to become the somebodies of the world we measured out our days with drama and reconciliation. The one thing that was always true was that we needed each other. A cup of sugar here and pots there meant that we lived in each other's homes and struggled to maintain any sort of privacy. Those who did keep others at bay were often thought to be filled with airs. Of course another reason for the lack of privacy was that houses were built on top of each other. Most of the people who did not need others were the happy families, the ones with both parents and the children who obeyed their parents and the parents whose wholesome example to people in general on how to get by in this life-inspired envy. The contrary was also very true. Some people regarded those families with 
so much suspicion, in a worse position were those that had cumulated some possessions; they became targets. The neighbourhood had little patience for the elusive ideals that those families represented. Each member on our street lived in a house that stewed in its own tale which almost always ended up being aired in one or other public brawl.

It became public knowledge that Meiki's mom was an alcoholic, which is why she, Meiki, had fallen pregnant. Bhut'Sipho did not have a wife, which is why he was such a womaniser. Mule was going to be a soccer star like his older brother which is why his parents had him drop out of school. Usually these brawls were started by lending a neighbour a pot and them not returning it or the placing of hot food in a Tupperware.

'Don't you talk about my child like that, at least she did not abort, we know how your family hates responsibility look at your brother, he has children all over God's earth.'

'Hoooo shem Ma ka Meiki (Meiki's mother) just say that your child has defeated you and let my brother be, Sipho is a grown man he is not like that daughter of yours who opens her legs for anything. Sies man!'

'Yazi'ni Ma ka Nelli (Nelli's mother) I don't want to see you near my house, and don't ever ask me for my pots! Anyway it's not like your function was nice, you borrowed my pots so that you could cook umgodu nje and the way you were going on and on one would have thought you were going to show us mara niks! That tripe is still blocking my throat I'm so full of it!'

'Ag man, let me be, I don't care about you. Jealous people never notice anything good anyway, you're a hard hearted witch, I will stay out of your way and you better stay out of mine or else you will eat blood!'

But as it went on, it was not long before folks of this street needed each other again; we always needed each other. You see the times were changing as times often are and the freedom violence was escalating to new heights. There were frequent protests at the soccer field that was three streets down. Most of the freedom fighters would approach the older children who were playing on the street and tell them that Chuck Norris had flown in to come meet Mandela at the soccer field and that they had to be there at a certain time without their parents. The name Mandela alone ensured the streets were cleared at the named time, we were all high on his fever. 'Viva' would reverberate all around the neighbourhood during the protests and the older children would come back pumped with a new light in their eyes. 
In those days, it was dangerous to travel to work. Boarding the train and making to work was an exception. It was almost impossible to climb a taxi and not take a different route or run late. Normal to drive your own car without it raising eyebrows as to how it was financed or subsequently get hijacked. It was a dangerous time and we all needed each other. The politics created the times but folks generally loved being close to each other and smelling the sweat of each other's backs. It made life worth it because for the most part it could be easy for life not to be worth it.

Then of course there were ridiculous things that kept life moving like the fall out of long time friends. Bra Simon and Bra John had been drinking buddies for decades since moving from their respective villages to come and find work in Joburg. This is the common thread between all the older generation that only the children are born in Gauteng. Nonetheless, on one of their drinking sprees Bra Simon ran out of money and Bra John naturally offered to cover him and since nothing was for old times' sake Bra Simon told him he would refund him at the end of the week when his wages were paid but he did not. Bra John, hot tempered as he was filled a quartz beer bottle with paraffin and a match inside and threw it into Bra Simon's house one Saturday morning. The window that the bottle had broken had a curtain shielding the inside which quickly caught fire and within seconds the house was in flames.

We were sleeping when a hurried rapping on the door woke us. 'Umlilo Ma ka Zaza. Fire!' The person then ran out of the gate and into the next yard to inform them as well. uMama broke through our bedroom door and violently pulled off our covers and told us to stop sleeping whilst our neighbours were in trouble. Alarmed at the abrupt manner of address so early in the morning, we jumped out of bed in excitement and slight irritation. The whole street came out. MaTema had her hands on her head screaming, 'Modimo, Modimo, oh Lord!' Her blue cotton night dress with lace trimmings revealed a bit of cleavage which I found a little embarrassed to see hang out for the whole world. Every neighbour offered their buckets. It did not take long to figure out what needed to be done. UTata was already with other men who had jumped the wall to try and save Bra Simon's belongings and the people inside. We were frantically filling buckets with water and throwing them into the house. The older boys were connecting hose pipes to various houses and spraying the flames from all angles, the yards were pretty close to each other so the pipes could reach. This action lasted for most of the day.

It was only then that the police were called and a new competition began; that of the eye witness accounts. The investigating officer asked people to form a line, since so many were willing to recount what had occurred in as much detail as possible much to the investigator's detriment. The investigating officer 
though, relishing his importance to the community continued to take notes and 'number phones' of people he thought were relevant for purposes of testifying. This impressed people; the fact that their observations could be worthy to a court of law. As the investigating officer progressed further along the line the accounts became outlandish and more heroic. The one hung on a tree to exterminate the fire, the other ran into the house after seeing the smoke from three streets down, and another pulled the little girl out and so forth. Others garnered attention by coughing uncontrollably, asking for water and when the investigating officer walked over to them, they blamed it on the heavy smoke but then quickly began telling the officer their accounts of what had transpired. Bra Simon and Bra John had fought right there in the middle of the street. 'I said I would pay you,' said Bra Simon. 'But you didn't,' replied Bra John. Bra Simon was a lightweight man, tall and slender with thin biceps that stretched out along his torso. He was no physical match for Bra John who had the weight of a normal man and who was used to tavern brawls due to his hot temper. They threw each other on the ground their backs dirty from rolling in the dust. Nobody interfered really because Bra Simon needed to vindicate his manhood after watching his house go up in flames for a ten rand debt. We all knew Bra John would not kill Bra Simon; not in front of his family.

The days rolled by after the fire. Bra Simon and his family lived with different neighbours on the street until they rebuilt the house. It turned out that the roof had suffered the most damage. The younger boys were commissioned to paint the house. Bra Simon's wife attended to the donated money for the windows and other people donated curtains or old furniture they had stored in their garages (which hardly ever had cars). Bra John and Bra Simon no longer spoke, though Bra Simon called Bra John 'leVenda le' with such contempt in his eyes that even we stopped playing with Tshilidizi (Bra John's child) for some time, fearing that our parent's houses might just be burnt down as well. The cold war did not last long; just a year. New Years Day was coming up.

New Years meant fireworks and new clothes; the only other time for new clothes was Christmas and confirmation. New Years also meant that we could countdown to the song of the year while stealing to some dark part of the street since only the main road had streetlights to drink Crown ciders in their gold and red cans. They were supplied to us by the older girls who also taught us salacious dances afterwards when we were light with merriment and a wash of warmth spreading over our bodies. UMama forbade us from going into peoples' backyards especially on busy days like New Years and on one year I finally knew why. We saw two figures, can't say who now, but they made sounds that we knew immediately our parents would have censored. We ran back to the party a little wiser now about backyards at night time. Each house on the street bought so many explosives to 
shoot off into the night until dawn coloured the sky then only the drunks kept the party going.

The rest of the street retired to prepare for the later hours of the day when there would be elaborate dishes prepared. The youth would be in their shortest items headed for a park in the city to have a picnic and braai, leaving in a convoy of taxis blasting the crowned song of the year. We spent most of our times at maTema's house sitting in her kitchen with the linoleum floor and the banana tree that blocked the kitchen light eating vanilla cake with grenadilla frosting. Her burly body sitting next to us asking if we wanted more of everything through her pink glasses. Wisdom etched all over her face. We always said yes. Besides, most of us never had grandmothers who baked and who let us sit in their lounges with our feet on the sofa. She was the grandmother we all yearned for but only ever saw on television. MaTema worked emakitchini, she was a domestic worker, and most times we saw her on the weekends when the aromas in her kitchen wafted onto the dusty street where we were constantly making a nuisance of ourselves with all the other children. Soon after the games would end we would find ourselves at her door, led there by our poverty for some and false nostalgia for others.

After New Years, folks generally buried the hatchet because when times were hard, one needed every available person to be called a friend. That was partly why Bra Simon and Bra John slowly found their way back to each other and when Bra Simon held a function to re-open his house, as though it were a place of memorial with a red ribbon tied onto the gate. It was Bra John who cut it; ironically.

The investigating officer never came back to call the relevant witnesses and it was just as well as that turned out to be the largest ceremony we ever attended for the building of a burnt roof. Sheep were slaughtered. The elders spoke to the ancestors. The church women prayed. The programme director entertained the crowd which was largely made up of families who lived on the street. There were tables upon tables covered in white cloth laden with all the salads and meat in the world and there Bra Simon and Bra John sat, reconciled, drinking a lala of traditional beer.

Then the happy times ended. UTata, Bra Simon and Bra John accompanied each other every morning since they all worked emafirmini, in the industrial areas of Johannesburg. UTata missed his train that morning having misplaced his wallet. Bra Simon and Bra John left him to catch the early train out. They were both killed. Shot several times by anonymous men who left as swiftly and deftly as they had come. Sixty dead, going to work. UTata tried again but he missed the train again. Sixty dead, going to work. Then a hundred. Then all Xhosa and Zulu boys became the hunted. Then all Zulu and Xhosa men were feared. The protestors at the soccer field were scattered by tear gas and bull horns, whips cracked to disperse the crowd. Kangaroo 
courts for snitches mushroomed and usually ended with tyre necklaces hanging on the accused's neck all black fumes and red flames with their heads shooting off their bodies.

UTata began using the car to go to work and with us inside they shot at him. He pressed the accelerator hiding his head under the steering wheel and rammed into the knees of the gunman who flew in all angles in the sky before landing as a heap on the side of the road as we sped on by. There was no peace, a locked door meant nothing for the style at that time was that they either kicked down the door and upon entering punished the occupants for their efforts or they pummelled the door down with arsenal without knocking first. Police sirens sounded all the time. Folks did not care about death they were so reckless. We, during those waves of violence, slept lightly on most nights forever worried about the slightest noise outside.

Then one day they charged into the house with guns so long it took two hands to carry them, but they were common thieves feasting on the times. They were not freedom fighters nor were they police informants or the police themselves. Four men walked in and asked for uTata's car keys. The leader slapped uTata around and the other man put a gun down uMama's throat. Her tears flowed so steadily down her face without a pinched noise or anything actually coming out of her, she kept her eyes on us all the time. I knew we were not going to be harmed, our bodies had not formed enough to be fodder for them but I wasn't so sure about uTata. They wanted to know where he kept the safe. The more he denied any knowledge of a safe the more the magazine of the gun brutally found his head. We knew not to cry, that might make them kill uTata but Cece didn't know that, she was a baby.

That irritated the one who was slapping uTata, he threatened irascibly to ease her discomfort permanently. The other one, the one who had a gun down mama's throat intervened and he ordered one of the other boys who were looting in the other rooms to take the baby to the next room with the rest of us. He had with him some gentleness that seemed so contrary to the vulgarity of his current act. It was to be years until mama confessed to me that she had once taught him at school. This interrogation continued for hours until they left with the car and some the appliances and groceries.

The gun uMama had eaten left her with an after taste so strong she stopped eating all together. She watched us all the time, paranoid about every stranger walking into our yard selling ice-cream or taking photographs for money. We tried to teach her the new hand game we had learnt from the television, the hand movements went along with the words:

South Africa,

We love you,

Our beautiful land, 
Let's show the whole world,

We can bring peace in our land!

We sang that song along with Leleti Khumalo, Sarafina as she was known, all the time infatuated with her caramel even tone skin and the confidence she exuded in the fact that we could actually achieve what the words aspired to do. We sang that song so much that the peace people came to give each household a white $t$-shirts with a blue and a white dove imprinted on the left breast of the $t$-shirt. On the other breast, all the way to the navel were the words of the song in black print. We learnt the song. We taught our parents the song. We taught Lerato, Bra Simons daughter the song. We taught maTema the song. It exploded but uMama hardly cared, she had eaten too much of that gun that day and wanted to leave. UTata too had seen enough, buried too many friends and had missed death enough to know that his angels had grown weary of him. It was to be some years before we left, officially. We were separated from the neighbourhood by our medium of instruction in the different schools we attended, in the manner in which we played there's-a-party-round-the-corner and how we only slept in the house where we returned to from another life. We left long before the day the white truck pulled up in front of the house.

MaTema cried the whole day. She begged my mother to reconsider, the times were changing. Hani was the last. The vote happened didn't, we all thought it wouldn't but it did. The children were getting good education. UMama would not hear it though. She longed for the taste of food again, her senses to be invigorated by something other than that gun that was lodged forcefully into her mouth by a boy who she had taught how to calculate fractions, she was determined. Meiki's mother told her never mind the old lady since she was probably jealous of her going to live the high life. 'You must come back and tell us what it feels like to be a Madam'. We did not see maTema before we left; we left with the first load the truck took. Our minds were high about finally living near our school friends and having a maid accompany us everywhere and not having to wait by the corner of the school on the pavement to be picked up by a red taxi that collected those like us who were mere visitors in the suburbs. Our loyalties were reasoned out like those of children, never looking back at people who knew the insides of our homes and whom we had needed all these years. The dust kicked up in the air carried us away in its restlessness.

And so a decade passed. The excitement of the suburbs soon cooled and in our sober moments we realised that we longed for the kind of party we had had on New Years or for the drama of saving a neighbour in need. We longed for a family with strangers. I longed for maTema. I thought about her all the time with her pink glasses. One time I had pulled them off her face. It was a Sunday after church and 
she was hosting us for lunch. The fourth lunch hosted by a family on the street we had attended after my mother's graduation from university. My mother sat in her gown, they all insisted she must wear it to every lunch, on the other end of the kitchen eating vanilla cake with the grenadilla frosting, the men were outside preparing the braai. This was normal: to have a braai after the formal meal. I pulled off the cat-eyed glasses off her face and wore them. The cat-eyed shaped sunglasses slid off my face, they were too big. She laughed heartily. I asked her about why she wore them all the time. Taking them and wearing them again she said: 'where else is there glamour in this life, in this dust?' Thereafter, she laughed so loud cupping my face in one of her soft fat hands, 'look at us, all of us, on this dusty street that hangs onto a person's palate so tightly choking the life out of them we need the glamour if not for the fashion then for ourselves, that is the Gospel!' She continued to laugh as she stood up to open a cupboard with canned peaches.

'You didn't know me when I was young. I wasn't beautiful but I had it elsewhere, where it mattered' she said, slapping her thighs suggestively her big arms jiggling with fat. 'in a few years you will know' then she laughed so loudly it spread to all of us, 'that is the Gospel'. 'Ma...' Mama laughed trying to cover up her mortification at maTema's unusually forward comments. I threw my eyes to the half empty Crown cider on the table. 'Ag man, they must know' she said waving away my mother's conservatism, 'no harm done'. Without asking she scooped canned peaches with the syrup onto my plate next to my thick slice of cake. 'No harm at all'. I remember her open her face laughing at her last comment, really throwing her head back and digging deep as if she realised seconds later the humour of it all. I cling onto that memory.

Opening the gate of the house, I walked around familiar territory noting the subtle changes, even the aging of things all the way to the kitchen door. I found Matlaku, her granddaughter sitting on the veranda kneading dough. My stomach sank as I thought about how I could have had those recipe's passed down to me and how these days I had my own ideas that vehemently resisted the scene currently playing itself in front of me but seeing Matlaku working from memory made me long for access to maTema's secrets on her domestic prowess. Matlaku looked up at me warily. 'Hello.' It took a minute for my face to shift focus in Matlaku's eyes. 'It cannot be!' she squealed raising herself up from her knees. Then we poked at each other, her rounded cheeks, my height, her wearing a dress, me wearing pants. We held each other in a long embrace, suspended in disbelief and relief that the moment was real.

'Come in come in,' she held my back with her hand covered with flour. The other arm cradled the bowl of dough that she set on the table and covered with a dish cloth for the dough to raise. She then 
washed her hands at the sink. I stood next to her. 'So I see people are extending,' I said and we shared a knowing laugh about the competitive nature of the people on this street.

'It started with Meiki's mother when she got promoted.'

'Promoted? Chesa! I'm sure nobody lived that down.'

'Eh! It's like you were here, she threw the biggest party on God's earth, bigger than Bra Simon's, and it lasted days. A few weeks later she began complaining incessantly about how everybody was so jealous of her success'

'She loves people being jealous of her ne?'

'How do you know her? That was when she started buying bricks and things every month end. She didn't tell anybody what she intended to build which of course is always a question that needs answers. She just said she should be left alone, complaining about jealousy and whatnot. Anyway we eventually heard from Bhut'Oupa, because she stopped greeting and talking to everybody. She said that when your mother graduated from university she used her best table cloths made from silk to host a huge lunch but when she moves up in the world in the world the only thing she gets is the party she threw for herself and you know mMa'Meiki, she never lets anything go. So Mama,' referring to maTema, 'sensing the impending doom joined together with the other women and secretly organised a party for her inviting people from even three streets up. Wwhooo friend! It was so huge you would have thought it was a wedding,' she began laughing heartily that she resembled maTema so much, 'anyway after that everywhere she went people called her Promotion'.

'And I bet she loved that' I said in raptures of laughter.

'Eh! How do you know these old people!' we laughed in unison. We sat in the kitchen eating the vanilla cake she had pulled out from the fridge.

'Do they still call her that? Has she stopped drinking?'

'Hai, she says she has but...I don't know. Do you ever know with these old people?' 'True. Where is maTema?'

'What do you mean?'

'Is she at work?'

'He e wena, you don't know?' Then suddenly I knew. 'We told Bhut'Oupa to tell you because he said he had a relative who lived in Pretoria. We thought when you guys didn't come to the funeral, maybe you had other arrangements plus Mama lost your mother's numbers after she came here after school one time.'

'No, we would have come,' I said annoyed at myself, ashamed even. 
'Yho, she was sick for long time, cervical cancer. She bled and bled and bled; it was awful.' Her voice filled with the memory of that time. She placed her fork on her plate. The flippant nature in which she spoke stung me a bit; she had the privilege and the time to reconcile herself with a world without maTema to speak about her this way.

Selfishly, I had assumed that she had remained frozen in that time and that only my life was asking me questions about who I am. It hurt to know she was mortal. 'But she loved you guys' Matlaku continued saying, "no matter who lived at number 56 they just were never the same, never quite fit into the groove of how we do things around here. She thought you guys were going to come back sometime, convinced herself really. She just could not believe that you would want to live elsewhere. You know old people.'

'I do,' I replied and I was left wondering about the sincerity of my answer. Matlaku put her saucer in the sink and walked into one of the rooms. I sat in silent grief, replaying the last time I had been on this street driving away in a white truck. I envied how Bra Simon and Bra John lived on, their ghost's still part of this changed world. I resented myself for never having said goodbye properly, for being a child. I thought about death briefly. Our silent twin who walks with us everywhere, quietly biding its time until cervical cancer became the catalyst or a swerving car or a gun. I felt centred and rooted to the truth of life- that we all die. 'These are yours,' Matlaku said coming back to sit down opposite me. I took the pink glasses from her hands. I smiled. 'My brother and I agreed that you would return one day, today, and that we would give them to you since you're the only one who seemed to love those ridiculous glasses.' 'That is the Gospel.' We smiled knowingly at each other, 'thank you'.

A few hours later, I made my rounds up and down the street greeting old friends. People enquired about my mother and if she ever received another degree. How old Cece was now and what were our numbers. I even ran into 'Promotion' herself and she began telling me about her promotion which I pretended to not know anything about which for some odd reason upset her terribly. Lerato, Bra Simon's daughter, holding her own child, kissed me on the mouth lightly as was the custom. She introduced the child who peered curiously from behind her mother. There were embraces all around. I promised to pass their greetings along to my parents and to drop by another time.

In my rearview mirror I watched them wave me off, my family of strangers. It looked like an old photograph you would find in a forgotten album, with the edges turning slightly red, rose coloured, with arbitrary trees framing the group that stood arranged in the middle of the photo wearing their widest smiles for the lens to capture forevermore. At an intersection, I pulled out my pink glasses and I put them on. This time they fit. I smiled thinking that this is how 
she had seen me all those years ago, through this haze of rose. I drove off. I continue to live after that visit, when I'm alone in a room filled with expectations or bored by the droning voice of uninspired lecturers I take myself back there. To the length of that street and I live it again, if only for a moment, I am in that kitchen with the window shielded by the banana tree eating vanilla cake with grenadilla frosting. 